\title{
OSTEOLOGY OF LIVING AND FOSSIL NEW WORLD QUAIL
}

By

J. ALAN HOLMAN

\begin{abstract}
A DISSERTATION PRESENTED TO THE GRADUATE COUNCIL OF THE UNIVERSITY OF FLORIDA

IN PARTIAL FULFILLMENT OF THE REQUIREMENTS FOR THE DEGREE OF DOCTOR OF PHILOSOPHY
\end{abstract}

UNIVERSITY OF FLORIDA

January, 1961 


\section{ACKNOWLEDGEMENTS}

I wlsh to extend my deepest thanks to Dr. Plerce Brodkorb for his valuable advice, helpful criticism, and constant encouragewent during the present study, as well as h1s untiring supervision throughout the course of my graduate program at the University of Florida.

Sincere thanks are also due the other members of my commlttee, Professors Eugene C. Bovee, Harold K. Brooks, James N. Layne, and E. Lowe Plerce.

Spec1al thanks are due Betty Holman, who typed the manuscript, and has given wuch encouragement throughout the course of the work. 
TABLE OF CONTENTS

Page

ACKNOWLEDGEMENTS . . . . . . . . . . . .

LIST OP TABLES . . . . . . . . . . . . .

2v

INTRODUCTION . . . . . . . . . . . . . .

MATERTALS AND METHODS

OSTEOLOGY OF LIVING GALLI

OSTEOLOGY OF LIVING NEW WORLD QUAIL . . . . .

FOSSIL BECORD OF NEW WORLD QUAIL . . . . . . . 


\section{LIST OF TABLES}

Table

Page

1. Intermembral Bat1os (Per Cent) of Gal11...

2. Intermembral Rat1os (Per Cent) of L1v1ng Specles of quall .............. 198

3. Bat1os (Per Cent) of Sternum, Pelv1s, and Sjasacrum in Living Quall ..........

4. Bat1os (Per Cent) of Ulna and Tiblotarsus in L1v1ag Guall ............... 204

5. Bat1os (Per Cent) of Femur in L1v1ng Qua11. 205

6. Bat1os (Per Cent) of Tarsometatarsus 10 L1v1ng Qua11............ 206

7. Measurements ( $1 \mathrm{~nm}$.) of L1ving Species of qual1 ............ 207

8. Subspec1f1c Variation (mo.) in Col1nus v1rg1n1anus ..................

9. S1ze Variation (mm.) In Fossil Collnus .. 222

10. Batios (Per Cent) of Femur and Tarsometatarsus of Fos81? Col1nus .......... 230

11. Bat1os (Per Cent) of Ulna and Synsacrum of Foss1l Collnus ...............

12. Rat1os (Per Cent) of Femur and T1b1otarsus of Foss11 Col1nus ...............

13. Bat1os (Per Cent) of Tarsometatarsus and Syracrum of Foss11 Col1nus .......... 


\section{INTBODUCTION}

The New World quall form a group of rather small-s1zed galliform blrds that range throughout the tropleal, subtroplcal, and temperate reglons of the Amer1cas. Most workers consider the New World quall to represent a subfam1ly of the Phasian1dae, the Odontophor1nae. The North Amerlcan specles are quite well known 1nd1vidually, and an especially voluminous ilterature on such subjects as ecologlcal toleranoe, food and nutrition, artific1al propogat1on, and miscellaneous ife history studies has grown out of the value of the group as game birds. The Central and South American forms are generally less well known. Crispens (1960) provides a source for 11terature on the economic and management aspects of North American species. B1dgway and Frledmann (1944) include an excellent bibllography on the taxonom1c aspects of both North and Central Amerlcan forms. Hellmayr and Conover (1942) give references to the 11 terature of South Amerlcan forms.

The classiflcation of galliform taxa at the family level and above 18 based malnly on 1nternal anatomy, whereas that of taxa below the family level is based malnly on external features. Thus, the New World quall are deflned on the followlng characters (RIdgway and Frledmann, 1944): 
(1) mandibular tomium serrated or toothed; (2) ta11 less than half to more than one-third as long as wing; (3) tarsus less than one-fourth to more than one-thlrd as long as wing;

(4) b111 relatively short and stout; (5) rectrices 10_14;

(6) tarsus w1thout spurs; (7) acrotarsium w1th a single row of broad, transverse scutellae; and (8) planta tars1 w1th two or more definite rows of moderately long scutellae, but also covered w1th small scales. The serrated or toothed mandibular tomlum is unlque in the order, whereas the other characters occur singly or in varlous comblnat1ons in other families and subramil1es.

Genera of New World qua1l are deflned on such characters as rat1os Involving the relative lengths of b111 and $11 \mathrm{mbs}$; development of head plumes; number of rectrices; relat1ve length of primarles; markings of chest, sldes, and flanks; shape of ta11; and scutellation of tarsus. Spec1es and subspecies are defined almost ent1rely on the basis of colorat1on, markings, and size.

Since there has been no comprehensive study of a comparat1ve nature concerning the internal anatomy of the genera of the New World qua11, both the 1nterrelat1onsh1ps of forms and thelr relationships to other Gall1 are poorly understood. A few works of an anatomical or physlological nature conta1n suggest1ons as to the affinities of the New World quall. Shufeldt (1909) compared skeletons of f1ve genera of North Amerlcan qua1l w1th those of varlous other gallinaceous b1rds, 
and remarked that bones of the chicken (Gallus gallus) and quall were bas1cally similar. Hudson, Lanzlllott1, and Edwards (1959) compared the pelvic muscles of 81 ve genera of New World quall and favored the Inclusion of the group w1th the pheasants and the peacocks in the subfamily Phaslaninae. Sibley (1960) studied the electrophoretic propertles of the egg-whlte protelns of four genera of North American quall and tentatively suggested that the New World quall appear to form as distinct a group as certaln other gall1forms wh1ch are given fam1ly or subfamlly rank in current classirications.

Th1s work 1ncludes three phases. The famllles and subfam1lies of the suborder Gall1 are redefined on the bas1s of osteological characters. The skeletons of the 11ving genera, specles, and subspecies of New World quall, 1nsofar as avallable, are described; and criteria are established for the various taxa. The osteological variations of the fossil materlal are evaluated. 


\section{MATEBIALS AND METHODS}

The skeletal collection of Dr. Plerce Brodkorb at the University or Florlda was supplemented by material borrowed from the Un1ted States National Museum (through Dr. Herbert Friedmann), University of M1ch1gan Museum of Zoology (through Dr. H. B. Tordoff), Un1vers1ty of Cal1forn1a Museum of Zoology (through Dr. Frank A. Pltelka), and Southern Il11nols Un1versity Wildife Eesearch Collection (through Dr. W. D. KIImstra). Foss11 specimens studied in the present work are In the Brodkorb collection at the Unlversity of Florida, the Un1versity of Oregon Museum of Natural H1story (through Dr. J. Arnold Shotwell), and the Texas Memor1al Museum (through Dr. John A. W11son).

The number of specimens studied is 11sted below. Incomplete skeletons are given in parentheses.

Fam1ly Crac1dae: M1tu m1tu 1, Crax klobulosa 1, Crax rubra 1, Penelop1na niger (1), Ortal1s vetula (4).

Fam1ly Tetraon1dae: Lyrurus tetr1x (2), Lagopus lagopus 1, Canachites canadens1s (2), Bonasa umbellus 2, Pedioecetes phasianellus 1 .

Fam1ly Num1didae: Num1da meleagr1s 2, Acryl11um vulturinum 7 . 
Fam1ly Meleagrididae: Meleagris gallopavo 8.

Fam1ly Phaslanldae, subfamlly Perdiclnae: Alectorls

graeca 2, Alector1s rufa (1), Erancollnus b1calcaratus (1),

Perd1x perd1x $1(+1)$, Coturn1x coturn1x $3(+1)$.

Fam1ly Phaslanldae, subfam1ly Phaslaninae: Lophophorus

1 mpejanus 1, Gennaeus nycthemerus 1, Gallus gallus 3 ,

Catreus wall1ch11 1, Phaslanus colchlcus 3, Chrysolophus

p1ctus 1, Arguslanus angus 1, Pavo cristatus 1, Pavo

mut1cus 2 .

Fam1ly Phasianldae, subfamily Odontophorinae:

Dendrortyx leucophrys 1, Philortyx Iasclatus 1, Oreortyx

plota 4, Callipepla squamata 4, Collnus virginianus

floridanus $9(+1)$, Colinus virginlanus virginianus $x$

floridanus 23, Colinus V1rginianus 1nsignis $2(+3)$, Collnus

virginianus coyolcos (1), Colinus virginianus virginianus

65. Col1nus nigrogular1s (2), Col1nus leucopogon 4,

Lophortyx callforn1ca $2(+1)$, Lophortyx gambel11 2,

Lophortyx douglas11 2, Odontophorus gujanens1s $1(+1)$,

Odontophorus stellatus 1, Odontophorus guttatus 1 ,

Dactylortyx thorac1cus 3, Cyrtonyz montezumae 3, Rhynchortyx clnctus 1 .

The fossil specimens include 795 elements, detalled in the body of the work.

Al1 measurements are 11 near and to the nearest tenth m1llimeter. Although 60 intramembral and interwembral ratios were taken, only those that proved userul are presented 
here1n.

Anatomical nomenclature follows that of Howard (1929). 


\section{OSTEOLOGY OF LIVING GALII}

The suborder Gall1 forms a very large group of almost world-w1de distribut1on, yet 1ts families are quite similar 1n bas1c morphology, and laterfam1l1al hybrids occur. These factors have made a natural classiflcation difflcult, and at present several systems are in use.

The classification generally followed in the United States 1s that of Wetmore (1930, 1951, and 1960). Wetmore divides the order Gell1formes into two suborders, the Op1sthocom1, wh1ch 1ncludes the hoatzlas, and the suborder Gall1 for the remalning groups. The suborder Gall1 18 divided 1nto two superfam111es, the Cracoldea, and the Phaslano1dea. The superfam1ly Cracoldea 1ncludes the Iam111es Megapod11dae (mound-bu1lders) and Cracldae (curassows). The superfam1ly Phaslanoldea 1ncludes the fam1lies Tetraonldae (grouse), Phaslanidae (pheasants, qua1ls, peacooks), Num1d1dae (gulneafowl), and Meleagrididae (turkeys).

Friedmann (1946) follows the classiflcation of Wetmore but further divides the Phasianidae 1nto three subfamilles, the Odontophor1nae (New World qua118), Perd101nae (Old World qua11s), and Phaslaninae (pheasants, junglefowls, and pea. cocks). 
Other authoritative interpretations are given by Stresemann (1959), who considers the Gall1 and Op1sthocom1 of Wetmore as separate orders; and Sibley (1960), who conslders the order Galliformes to be composed of three famllies, the Megapodildae, the Phaslantdae (w1th subfam1lies Phaslantnae, Meleagridinae, Num1dinae, Tetraoninae, and (racinae), and the opisthocomidae.

A somewhat intermediate view is taken by Mayr and Amadon (1951), who conslder the order Gall1 (Galliformes of Wetmore) to be composed of I1ve fam111es, Megapodildae, Cracldae, Phasianidae (w1th subfamllies Phasianinae, Numidinae, and Tetraoninae), Meleagrididae, and Oplsthocomidae.

The classification of Wetwore will be used in the following section on descriptive osteology but w1ll be mod1fled later. Some of the more definitive osteological characters of the suborder Gall1 are Included below. Axtal skeleton.--The palate is schlzognathous and has both a vomer and a well developed baslpterygold process. The nasal fossae are holorhinal, and the mandible has a long angular process. Sixteen cervical vertebrae are present, and their haemapophyses are unringed. The sternum has a perforated common spine, long anterior lateral processes, two pairs of metasternal notches, and Its xiphold area 1s long and narrow. Appendicular skeleton.--The furculum is Y-shaped, and has a large hypocleldium. The coracold is long, stralght, 
and narrow, and 1ts procoracold process 1s small. The

humerus is short and stout, and 1ts shaft has a sigmold curve. The caput hunerus 18 large and round, the coracohumeral groove is Indistinct, and the deltold crest is short, with 1ts summit inflected. The ecteplcondylar process 18 rudisentary. The ulna 18 short, curved, flattened medially, and has the distal end enlarged. The carpometacarpus has the metacarpal III produced beyond the metacarpal II, and the metacarpal I is directed posterlorly. The femur is long and curved, w1th 1 ts anterior intermuscular line cont1nuous w1th the trochanter, and 1ts external condyle produced lower than the 1nternal condyle. The t1blotarsus 18 long, with 1 ts outer cnemial crest polnted, and with a supratendinal bridge at the distal ead. The tarsometatarsus is flattened anteroposterlorly, and Its middle condyle is much the longest.

The present study of the osteology of Recent Gall1 was undertaken to deflue more exactly the Odontophorinae as a taxonomic unit, and to shed light on the relative importance of the characters of 1 ts fossil and Recent members. Nevertheless, osteological characters that appear to be useful In evaluating the status of the other taxa of the Gall1 have been Included. Those skeletal elements most frequently found as foss1ls have been ut1l1zed for the study.

\section{Family CRACIDAE Carus 1868}

Bostrum.--(1) Long, but deep, h1ghly compressed, and 
strongly decurved, w1th a dorsal bony knob in Mitu and Crax. Sternum.--(2) Manubrial splne w1th a very large dorsal foramen. (3) Anterlor lateral processes short, broad, straight, and at right angles to long axis of sternum. (4) Anterlor area of sternal plate h1ghly pneumatic. (5) Inner notch of sternum short, less than half length of sternum, thus posterior lateral and posterior medial processes arlsing 1ndependently from sternum.

Coracold.--(6) Medial surface of head rounded.

(7) Brachlal tuberosity without overhanglng ventral portion. (8) Dorsal intermuscular line not sharply ralsed distally. (9) Ventral Intermuscular IIne terminating near lateral end of sternal facet. (10) D1stal dorsal face w1th large pneumatic fossa. (11) Sterno-coracoldal process without terminal knob.

Scapula.-- (12) Ventral base of glenold facet with a large pneumat1c fossa. (13) Area medlad to glenold facet in dorsal aspect usually w1thout depression (w1th slight depression in (rax). (14) Bridge between acromion process and glenold facet non-pneumat1c. (15) Acromion process deflected. (16) Dorsal base of shaft non-pneumatic. (17) Blade usually very short and wide (moderately short and w1de in (0rtal1s), w1thout dorsal groove, but w1th 1ts dorsal surface very shallowly concave, its apex without terminal expansion.

Humerus.--(18) Pneumat1c fossa very small, w1th 1nternal 
anconal border of blclpital crest wide, and with Inner shelf extending from medial bar to Internal blcipltal surface. (19) Fossa II (Ashley, 1941) absent. (20) B1c1p1tal crest usually with 1ts lateral margin rounded (w1th 1ts lateral margin truncated in Mitu).

UIna.--(21) External cotyla well developed, w1th 1 ts margin usualiy rounded throughout (w1th dorsal border flattened in Crax globulosa).

Carpometacarpus.--(22) P1s1form process obsolete, and at level of 1 ts 11 gamental attachment. (23) Intermetacarpal tubercle obsolete, represented only by a minute polnt. (24) Carpal trochlea w1th 1 ts external rim contlnulng distad beyond ligemental notch.

Pelv1s.--(25) Relat1vely narrow and deep. (26) Pect1neal process obsolete, w1th a pneumatic foramen on 1 ts anterlor border. (27) Anterior portion of renal depression W1th a large pneuratic fossa. (28) Renal bar usually broad (slender in Crtal1s), without pneumatio foramen.

Femur.-- (29) Head swollen, 1ts dorsal border above level of $111 a c$ facet. (30) Dorsal crest of trochanter low. (31) Area mediad to anterior border of trochanter w1 thout preumat1c fosse.

miblotarsus.-- (32) Inner cnemlal crest arising from shaft well below level of outer cnemlal crest. (33) Internal distal Iigamental attachment within I1mits of border of internal condyle. (34) External distal ligamental attachment not produced 
as a tubercle.

Tarsometatarsus.--(35) Hypotarsus w1th one closed calcaneal canal. (36) Inner calcaneal ridge w1 thout d1stal extension. (37) Posterior shaft without spur core. (38) Trochlea for diglt II at level of trochlea for diglt IV. (39) Poster1or metatarsal groove deeply excavated, w1th 1 ts lateral margin swinging gently onto posterior face of shaft. (40) Medial I1p of Internal cotyla weakly elevated, below level of Intercotylar prominence. (41) Intercotylar prom1. nence weakly produced.

Interwembral proportlons.--(42) U1na/humerus 106-107 per cent (Table 1). (43) Carpometacarpus/ulaa 49-50 per cent. (44) Femur/t1blotarsus 67-69 per cent. (45) Tarsometatarsus/ femur 94-102 per cent. (46) Tarsometatarsus/t1b1otarsus 64-69 per cent. (47) UIna/femur 104 per cent. (48) Ulna/t1blotarsus 71 per cent. (49) Carpometacarpus/femur $52-53$ per cent. (50) Carpometacarpus/tarsometatarsus $51-57$ per cent. (51) I11um/sternum 92 per cent.

Fam11y TETRAONIDAE V1gors 1825

Rostrum.--(1) Long and shallow, slightly decurved, and w1thout a dorsal bony knob.

Sternum.-- (2) Manubrial splne usually w1thout dorsal foramen (w1th an obsolete dorsal foramen in Pedloecetes). (3) Anterior lateral processes elongate and slender, moderately decurved, and nearly parallel to long axis of 
sternum. (4) Anterior area of sternal plate slightly pneumat1c. (5) Inner notch of sternum long, more than half length of sternum, thus posterlor lateral and posterior medial processes arlsing from a common base. Coraco1d.--(6) Medial surface of head rounded. (7) Brachial tuberosity with overhanglng ventral portion. (8) Dorsal Interwuscular line sharply raised distally. (9) Ventral 1ntermuscular 11 ne terminating at t1p of sternocoracoldal process. (10) Distal dorsal face with large pneumatic fossa. (11) Sterno-coracoldal process ending in a terminal knob.

Scapula.-- (12) Ventral base of glenold facet w1 thout preumatic fossa. (13) Area mediad to glenold facet in dorsal aspect w1thout depression. (14) Bridge between acromion process and glenold facet with a large pneumatic fossa. 12:" i.promion process deflected. (16) Dorsal base of shaft non-pneumatic. (17) Blade moderately short and wide, w1thout dorsal groove, but with 1 ts dorsal surface shallowly concave, 1 ts apex expanding terminally.

Humerus.-. (18) Pneumat1c fossa moderately large, with 1nternal anconal border of blclpltal crest wide, usually w1 thout lnner shelf (w1th inner shelf extending from medial bar to internal bicipital surface in Bonasa). (19) Fossa II obsolete. (20) B1c1pital crest with 1ts lateral margin rounded.

Ulna.--(21) External cotyla well developed, w1th 1ts 
margin rounded throughout.

Carpometacarpus.--(22) P1s1form process obsolete, and at level of 1 ts 11 gamental attachment. (23) Intermetacarpal tubercle well developed, extending to level of metacarpal III. (24) Carpal trochlea with 1 ts external rim ending at 11 gamental notch.

Pelv1s.-- (25) Very w1de and shallow. (26) Pectineal process obsolete, w1th p peumatic foramen on 1 ts medial face. (27) Anterior portion of renal depression without pneumat1c fossa (w1th a few pneumatic perforations in Bonasa). (28) Renal bar broad, usually w1th a large pneumatic foramen (without pneumatic foramen in Pedioecetes).

Femur.-- (29) Head swollen, 1 ts dorsal border above level of Illac facet. (30) Dorsal crest of trochanter moderately h1gh. (31) Area mediad to anterior border of trochanter w1th a pneumat1c fossa.

T1b1otarsus.-- (32) Inner cnemial crest ar1sing from shaft well below level of outer cnemial crest. (33) Internal distal I1gamental attachment within 11mits of border of 1nternal condyle. (34) External distal 11gamental attachment not produced as a tubercle.

Tarsometatarsus.--(35) Hypotarsus with one closed calcaneal canal. (36) Inner calcaneal ridge usually extending three-fourths the way down shaft as a sharp ridge (w1thout distal extension in Lagopus). (37) Posterior shaft without spur core. (38) Trochlea for diglt II elevated above level 
of trochlea for diglt IV. (39) Posterlor metatarsal groove moderately excavated, w1th 1 ts lateral targin swinglng abruptly. onto posterior face of shaft. (40) Medial 11p of internal cotyla elevated to level of intercotylar prominence. (41) Intercotylar prominence well produced.

Intermembral proportlons.--(42) UIna/humerus 92-94 per cent (Table 1). (43) Carpometacarpus/ulna 58_62 per cent. (44) Femur/t1b1otarsus 75-80 per cent. (45) Tarsometatarsus/fenur 74 per cent. (46) Tarsometatarsus/t1b1otarsus 50-56 per cent. (47) U1na/femur 83-94 per cent. (48) Ulna/tiblotarsus $62-75$ per cent. (49) Carpometacarpus/femur 51-55 per cent. (50) Carpometacarpus/tarsometa_ tarsus 69-83 per cent. (51) Illum/sternum 69-80 per cent.

Family PHASIANIDAE V1gors 1825

Subfam1ly Odontophor1nae Gray 1846

Rostrum.--(1) Short and deep, strongly decurved, and without a dorsal bony knob.

Sternum.-- (2) Manubrial splne w1thout dorsal foramen. (3) Anterlor lateral process elongate and slender, stralght or slightly decurved, and nearly parallel to long axis of sternum. (4) Anterior area of sternal plate usually only slightly pneumatic (non-pneumatio in Cyrtonyx, Dectylortyx, Odontophorus, moderately pneumatic in oreortyx). (5) Inner notch of sternum long, more than half length of sternum, thus posterior lateral and posterior medial processes 
arising from a common base.

Coraco1d.-- (6) Med1al surface of head rounded.

(7) Brachlal tuberos1ty w1th overhanglng ventral port1on.

(8) Dorsal intermuscular ine sharply ralsed distally.

(9) Ventral intermuscular inge usually terminating at tip of sterno-coracoldal process (terminating in midale of distal border of sterno-coracoldal process in Dendrortyx).

(10) D1stal dorsal face w1 thout pneumat1c fossa. (II) Sternocoracoldal process usually ending in a terminal knob (w1th an obsolete terminal knob in Philortyx, without terminal knob in Dendrortyx).

Scapula.-.-(12) Ventral base of glenold facet without pneumatic fossa. (13) Area mediad to glenold facet in dorsal aspect with a depression. (14) Bridge between acromion process and glenold facet non-pneumat1c. (15) Acromion process deflected. (16) Dorsal base of shaft non-pneumatic. (17) Blade very elongate, w1th its dorsal surface deeply grooved throughout, and with 1 ts apex expanding terminally. Humerus.--(18) Pneumatic fossa much enlarged, thus Internal anconal border of blclpital crest narrow, usually w1thout 1nner shelf (with 1nner shelf in Odontophorus gujanensis extending from medial bar to internal biclpital surface. (19) Fossa II usually well developed (obsolete in Dendrortyx and Odontophorus). (20) B1c1p1tal crest w1th 1 ts lateral margin rounded.

Ulna.--(21) External cotyla well developed, usually 
w1th 1 ts margin rounded throughout (margin flattened in Dendrortyx, and odontophorus guttatus).

Carpometacarpus.--(22) P1s1form process produced medlally, thus extending well beyond level of 1ts ligamental attachment. (23) Intermetacarpol tubercle well developed and usually extending to level of metacarpal III (not reachlng level of metacarpal III in some 1ndividuals of Cyrtonyx). (24) Carpal trochlea w1th 1 ts external rim ending at ligamental notch.

Pelv1s.-- (25) Pelvis relat1vely narrow and deep. (26) Pectineal process obsolete, usually without pneumatic foramen (with a pneumatic foramen on 1 ts aedial face in Dendrortyx). (27) Anterior portion of renal depression w1 thout pneumatic fossa. (28) Renal bar slender in Dendrortyx, Ph1lortyx, Oreortyx, Call1pepla, Collnus, and Lophortyx, broad in Rhynchortyx, Cyrtonyx, Dectylortyx, and Odontophorus, w1thout pneumat1c foramen.

Fenur..--(29) Head swollen, 1 ts dorsal border above level of $111 \mathrm{ac}$ facet. (30) Dorsal crest of trochanter moderately h1gh 1n Ph1-ortyx, Oreortyx, Call1pepla, Dactylortyx, and most Lophortyx, low in Bhynchortyx, Cyrtonyx, Odontophorus, and most colinus. (31) Area mediad to anterior border of trochanter without a pneumatic fossa.

\section{Tiblotarsus.-- (32) Inner cnemial crest arieing from} shaft well below level of outer cnemial crest. (33) Internal distal ligamental attachment within $11 \mathrm{~m} 1 \mathrm{ts}$ of border of 
1nternal condyle. (34) External d1stal 11 gamental attachment not produced as a tubercle.

Tarsometatarsus.--(35) Hypotarsus usually with two closed calcaneal canals (one closed calcaneal canal in Dendrortyx and Bhynchortyx, usually one in Oreortyx). (36) Inner calcaneal ridge w1thout alstal extension. (37) Posterior shaft w1 thout spur core. (38) Trochlea for Alglt II elevated above level of trochlea for alglt IV. (39) Poster1or metatarsal groove moderately excavated, w1th 1ts lateral margin swinglng abruptly onto posterior face of shaft. (40) Medial 11p of Internal cotyla elevated to level of Intercotylar proalnence. (41) Intercotylar prominence well produced.

Intermembral proport1ons...-(42) U1na/humerus 86-102 per cent (Table 1). (43) Carpometacarpus/ulna $55-63$ per cent. (44) Femur/t1b1otarsus 78 per cent. (45) Tarsometataraus/ femur 70_88 per cent. (46) Tarsometatarsus/t1b1otarsus 53-63 per cent. (47) UIna/femur 68-93 per cent. (48) Ulna/ t1blotarsus 45-47 per cent. (49) Carponetacampus/fenur 37-52 per cent. (50) Carpometacarpus/tarsometatarsus 42-74 per cent. (51) I11um/sternum $65-89$ per cent.

Subfam11y Perdiclnae Bonaparte 1838

Rostrum.--(1) Long and shallow, usually sl1ghtly decurved (very silghtly decurved in Coturn1x), and without a dorsal bony krob. 
Sternum.-- (2) Manubrial spine w1thout dorsal foramen. (3) Anterlor lateral process elongate and slender, stralght or slightly decurved, and nearly parallel to long axis of sternum. (4) Anterior area of sternal plate usually only slightly pneumatic (non-pneumatic in Coturn1x). (5) Inner notches of sternum long, more than half length of sternum, thus posterior lateral and posterior medial processes arising from a common base.

Coraco1d.-- (6) Medial surface of head rounded. (7) Brachial tuberosity w1th overhanglng ventral portion. (8) Dorsal 1ntermuscular line sherply ralsed distally. (9) Ventral 1ntermuscular ine usually terminating at tip of sterno-coracoldal process (terminating at lateral end of sterbal facet in Coturn1x). (10) D1stal dorsal face w1thout pneumatic fossa. (11) Sterno-coracoldal process ending in a terminal knob.

Scapula.--(12) Ventral base of glenold facet without pneumatic fossa. (13) Area mediad to glenold facet in dorsal aspect with a depression. (14) Bridge between acrowion process and glenold facet non-pneumatic. (15) Acromlon process deflected. (16) Dorsal base of shaft non-pneumatic. (17) Blade very elongate and narrow, w1th 1 ts dorsal surface shallowly grooved in Coturnix; moderately elongate and narrow with 1 ts proximal and distal dorsal surface grooved In Alector1s; moderately elongate with 1 ts dorsal surface flat in Perdix; apices expanding terminally in all above 
forms.

Humerus.--(18) Pneumat1c fossa usually much enlarged, thus internal anconal border of blc1pltal crest usually narrow (fossa moderately large with internal anconal border of biclpital crest wide in Perd1x); usually w1thout 1nner shelf (with inner shelf in Perdix extending from medial bar to 1nternal blclp1tal surface). (19) Fossa II well developed in Coturn1x, weakly developed in Alector1s, obsolete in Perdix. (20) B1c1pital crest w1th 1ts lateral margin rounded. Ulna.--(21) External cotyla well developed, w1th 1 ts margin rounded throughout.

Carpometacarpus.--(22) P1s1form process usually obsolete and thus at level of 1 ts 11 gamental attachment (produced med1ally, thus extend1ng well beyond level of 1 ts 11 gamental attachment in Coturn1x). (23) Intermetacarpal tubercle usually well developed and extending to level of metacarpal III (very weakly deve?uped and not reaching metacarpal III 1n Coturn1x), (24) Carpal trochlea w1th 1ts external rim ending at I1gamental notch.

Pelv1s.--(25) Pelv1s relat1vely narrow and deep. (26) Pectineal process well developed, long and narrow, without pneumatic foramen. (27) Anterior portion of renal depression w1thout pneumatic fossa. (28) Renal bar usually broad (slender in Coturn1x), and with a pneumat1c foramen. Femur.-- (29) Head swollen, 1ts dorsal border above level of 111 ac facet. (30) Dorsal crest of trochanter moderately 
high. (31) Area mediad to anterior border of trochanter w1 thout a pneumatic fossa.

Tlblotarsus.--(32) Inner cnemlal orest usually arlsing from shaft at level of outer cnemial crest (arislag from shaft well below level of outer cnemlal crest in Coturnix). (33) Internal distal 11gamental attachment within lim1ts of border of 1nternal condyle. (34) External distal 11gamental attachment not produced as a tubercle.

Tarsometatarsus:--(35) Hypotarsus with one closed calcaneal canal. (36) Inner calcaneal ridge usually without distal extension (extending about half-way down shaft as a sharp ridge in Alector1s). (37) Posterlor shaft usually w1thout spur core (w1th rudimentary spur core in male Alector1s). (38) Trochlea for digit II elevated above level of trochlea for diglt IV. (39) Posterior metatarsal groove moderately excavated with 1 ts lateral margin swluging abruptly onto posterior face of shaft. (40) Medial l1p of Internal cotyla elevated to level of intercotylar prominence. (41) Intercotylar prominence well produced.

Intermembral proportions.-- (42) U1na/humerus $84-96$ per cent (Table 1). (43) Carpometacarpus/ulna $59-68$ per cent. (44) Femur/t1blotarsus 74-80 per cent. (45) Tarsometatarsus/femur 75-81 per cent. (46) Tarsometatarsus/t1blotarsus $57-62$ per cent. (47) Ulna/femur 76-83 per cent. (48) Ulna/ t1b1otarsus 59-65 per cent. (49) Carpometacarpus/femur 47-53 per cent. (50) Carpometacarpus/tarsometatarsus 62-69 
per cent. (51) Il1um/sternum 83-95 per cent.

Subfam1ly Phasianinae Gray 1840

Bostrum.--(1) Very long and shallow, slightly decurved, and w1 thout a dorsal bony knob.

Sternum.--(2) Manuiorial splne usually w1thout dorsal foramen (W1th moderately large dorsal foramen in Catreus, Phaslanus, and Arguslanus). (3) Anterior lateral process usually slightly elongate and slender (shorter and broader in Pavo), usually slightly decurved, (strongly decurved in Gennaeus and (atreus), nearly parallel to long axis of sternum. (4) Anterlor area of sternal plate usually only slightly pneumatic (moderately pneumatic in Gennaeus and Chrysolophus). (5) Inner notches of sternum long, more than half as long as sternum, thus posterior lateral and posterior medial processes arising from a common base.

Coraco1d.--(6) Medlal surface of head rounded.

(7) Brachial tuberos1ty w1th overhang1ng ventral portion.

(8) Dorsal intermuscular I1ne usually not sharply raised distally (ralsed slightly in Gallus and Chrysolophus).

(9) Ventral intermuscular ine usually terminating near lateral end of sternal facet (terminating at tip of sternocoracoldal process in Gallus, Catreus, and Argustanus). (10) Distal dorsal face with large pneumat1c fossa. (11) Sterno-coracoldal process ending in obsolete terminal knob. 
Scepula.-- (12) Ventral base of glenold facet usually w1 thout preumat1c fosse (w1th small pneumatic fossa in Arguslanus). (13) Area mediad to glenold facet usualiy w1thout depression (w1th a slight depression in Lophophorus, Phaslanus, and Chrysolophus). (14) Bridge between acromion process and glenold facet usually non-pneumatic (slightly pneumatic in Argusianus, with a large pneumatic fossa in Pavo). (15) Acromion process deflected. (16) Dorsal base of shaft non-pneumatic. (1.7) Blade usually moderately short and w1de, w1th 1 ts dorsal surface without dorsal groove, but w1th 1ts dorsal surface shallowly concave, and with 1 ts apex expanding terminally (very short and wide without dorsal groove, but with 1 ts dorsal surface very shallowly concave, and with 1 ts apex w1thout terminal expansion in Pavo). Humerus.-- (18) Pneumatic fossa moderately large, w1th Internal anconal border of b1cipital crest wide, and w1th lnner shelf extending from medial bar to internal blcipltal surface. (19) Fossa II obsolete. (20) Blclpital crest with 1ts lateral margin rounded.

U1na.--(21) External cotyla well developed, w1th 1 ts margin usually rounded throughout (truncated in Arguslanus). Carpometacarpus.--(22) P1s1form process prođuced medially, thus extending well beyond level of 1 ts 12 gamental attachwent. (23) Intermetacarpal tubercle usually well developed (weakly developed in Pavo), usually extending to level of metacarpal III (not reaching level of metacarpal 
III in Gennaeus and Catreus). (24) Carpel trochlea with its external rim ending at ligamental notch.

Pelv1s.-- (25) Pelv1s relatively narrow and deep.

(26) Pectineal process usually well developed, long and narrow (obsolete in Paro cristatus), with pneumatio foramen on Its medial face. (27) Anterior portion of renal depression without pneumatic fossa, but with a few small foramina in Lophophorus, Gallus, Catreus, Arguslanus, and Pavo..

(28) Renal bar broad, usually w1thout pneumatic foramen (w1th a small pneumatic foramen in Argusianus).

Ferur.--(29) Head swollen, its dorsal border above level of Iliac facet. (30) Dorsal crest of trochanter moderately $\mathrm{migh}$. (3l) Area mediad to anterior border of trochanter usually w1th pneumatic fossa (pneumatio fossa laterad to posterior aspect of head in Argusianus, without pneumatic fossa in Lophophorus and Gallus).

Tlbiotarsus..-(32) Inner cnemlal crest ar1sing from shaft well below level of outer onemlal crest. (33) Internal distal ligamental attachment within 11mits of border of Internal condyle. (34) External distal ligamental attachment not produced as a tubercle.

Tarsometatarsus.--(35) Hypotarsus w1th one closed calcaneal canal. (36) Inner calcaneal ridge usually extending about three-fourths the way down shaft as a sharp ridge (w1thout distal extension in Gallus). (37) Posterlor shaft w1th spur core in male. (38) Trochlea for alglt II elevated 
above level of trochlea for digit IV. (39) Posterior metatarsal groove moderately excavated, w1th 1ts lateral margin swinglng abruptly onto posterior face of shaft. (40) Medial $11 p$ of Internal cotyla elevated to level of Intercotylar prominence. (4I) Intercotylar prominence well produced. Intermembral proport1ons.--(42) Ulna/humerus 88.103 per cent (Table 1). (43) Carpometacarpus/ulna $51-60$ per cent. (44) Femur/t1blotarsus 57-77 per cent. (45) Tarsometatarsus/ femur 76-121 per cent. (46) Tarsometatersus/t1blotarsus 57-72 per cent. (47) Ulna/femur 69-114 per cent. (48) Ulna/ t1blotarsus 49-72 per cent. (49) Carpometacarpus/femur 38-59 per cent. (50) Carpometacarpus/trarsometatarsus 39-66 per cent. (51) IIIum/sternum 73-95 per cent.

Fam1ly NUMIDIDAE Sharpe 1891

Rostrum.-- (1) Long and shallow, slightly decurved, and without a dorsal bony knob.

Sternum.--(2) Manubrial spine w1th a moderately large dorsal foramen. (3) Anterlor lateral processes short, broad, straight and at about 45 degrees angle to long axis of sternum. (4) Anterior area of sternal plate moderately pneumatic. (5) Inner notch of sternum long, more than half length of sternum, thus posterior lateral and posterior medial processes arlsing from a common base. Coracold.--(6) Medial surface of head rounded. (7) Brachial tuberosity with overhang1ng ventral portion. 
(8) Dorsal 1ntermuscular line only slightly ralsed distally.

(9) Ventral 1ntermuscular line terminating near lateral end of sternal facet in Acryllium, near t1p of sterno-coracoldal process in Numida. (10) Distal dorsal face w1thout pneumatic fossa. (11) Sterno-coracoldal process ending in obsolete terminal knob.

Scapula.--(12) Ventral base of glenold facet w1thout pneumat1c fossa. (13) Area mediad to glenold facet w1 thout depression in Num1da, with slight depression in Acryllium. (14) Brldge between acromion process and glenold facet nonpneumat1c. (15) Acromion process deflected. (16) Dorsal base of shaft non-pneumat1c. (17) Blacie very short and w1de, w1 thout dorsal groove, but w1th 1ts dorsal surface shallowly concave; 1 ts apex expanding terminally in Numlda, w1thout terminal expansion in Acryll1um.

Humerus.-. (18) Pneumat1c fossa small, w1th internal anconal border of blcipital crest wide, and with inner shelf extending from medial bar to internal biclpital surface. (19) Fossa II obsolete. (20) Blc1pital crest with 1ts lateral margin truncated.

Ulna.--(21) External cotyla well developed in Numlda (only moderately well developed in Acryll1um), rounded throughout.

Carpometacarous.--(22) P1siform process obsolete and at level of 1 ts 11 gamental attachment in Acryll1um, produced medially, thus extending well beyond level of $1 \mathrm{ts}$ ligamental 
attachment in Num1de. (23) Intermetacarpal tubercle absent. (24) Carpal trochlea with 1 ts external rim ending at 11 gamental notch.

Pelv1s.--(25) Pelvis relatively narrow and deep.

(26) Pectineal process obsolete, w1thout pneumat1c foramen.

(27) Anterior portion of renal depression w1th a large pneumat1c fossa in Acryll1um, with a moderately large pneumatic fossa in Num1de. (28) Renal bar broed, without pneumat1c foramen.

Femur.--(29) Head swollen, 1ts dorsal border above level of 111ac facet. (30) Dorsal crest of trochanter moderately high. (31) Area mediad to anterior border of trochanter without pneumatic fossa.

T1b1otarsus.--(32) Inner cnemlal crest arlsing from shaft well below level of outer cnemial crest in Acryllium, at level of outer cnemial crest in Numlda. (33) Internal d1stal 11gamental attachment within limlts of border of Internal condyle. (34) External alstal I1gamental attachment not produced as a tubercle.

Tarsometatarsus.--(35) Hypotarsus w1th one closed calcaneal canal. (36) Inner calcaneal ridge w1 thout spur core. (37) Posterior shaft without spur core. (38) Trochlea for diglt II elevated above level of trochlea for diglt IV. (39) Posterior metatarsal groove moderately excavated, with Its lateral margin swinging abruptly onto posterior face of shaft. (40) Medial 11p of Internal cotyla elevated to level 
of latercotylar prominence. (41) Intercotylar prominence well produced.

Interwembral proportions.--(42) Ulna/humerus $95-111$ per cent (Table 1). (43) Carpometacarpus/ulna $48-55$ per ceat. (44) Femur/t1blotarsus 63-76 per cent. (45) Tarsometatarsus/ femur $83-114$ per cent. (46) Tarsometatarsus/t1blotarsus 61-72 per cent. (47) UIna/femur 91-111 per cent. (48) UIna/ t1blotarsus 64-72 per cent. (49) Carpometacarpus/femur 49-57 per cent. (50) Carpometacarpus/tarsometatarsus 48.60 per cent. (5I) Il1um/sternum 88-94 per cent.

Fam1Iy MELE GRIDIDAE COUEB 1874

Bostrum.--(I) Long and shallow, very sl1ghtly decurved, and w1 thout a dorsal bony knob.

Sternum.--(2) Manubrial spine without dorsal foramen. (3) Anterior lateral processes elongate and slender, moderately decurved, and nearly parallel to long axis of sternum. (4) Anterior area of sternal plate moderately pneumatic. (5) Inner notch of sternum long, more than half length of sternum, thus posterior lateral and posterior medial processes arising from a common base.

Coracold.--(6) Hedilal surface of head much flattened.

(7) Brachlal tuberosity w1thout overhanging ventral portion.

(8) Dorsal intermuscular 11ne not sharply ralsed distally.

(9) Ventral interwusoular line terminating near lateral end of sternal facet. (10) Distal dorsal face with large preu. 
mat1c fossa. (11) Sterno-coracoldal process ending in obsolete terwinal knob.

Scapula..-(12) Ventral base of glenold facet without pneumat1c fossa. (13) Area mediad to glenold facet without depression. (14) Bridge between acromion process and glenold facet non-pneumatic. (15) Acromlon process stralght.

(16) Dorsal base of shaft with a pneumatic fossa. (17) Blade very short and w1de, w1thout dorsel groove, but with 1 ts dorsal surface very shallowly concave, and with 1 ts apex expanding terminally.

Humerus.-- (18) Pneumat1c fossa sma1l, w1th 1nteral anconal border of blcipltal crest wide, and with inner shelf extending from medial bar to internal bicipital surface. (19) Fossa II obsolete. (20) External cotyla only weakly developed, w1th 1 ts margin truncated.

Carpometacarpus,--(22) P1sifort process produced medially, thus extending well beyond level of 1 ts 11 gamental attachment. (23) Intermetacarpal tubercle well developed, extending to level of metacarpal III. (24) Carpal trochlea with 1 ts external rim ending at 11 gamental notch.

Pelv1s.--(25) Pelvis relatively narrow and deep. (26) Pectineal process obsolete, w1th small pneumat1c foramina. (27) Anterlor portion of renal depression non-pneuwat1c. (28) Real bar very broad, without pneumatic foramen.

Femur.--(29) Head flattened, 1ts dorsal border at level 
of 1llac facet. (30) Dorsal crest of trochanter very high. (31) Area mediad to anterior border of trochanter without pneumat1c fossa.

I1blotarsus.-- (32) Inner cnemial crest usualy arising from shaft well above level of outer cnemlal crest. (33) Internal distal 11 gamental attachment of ten extending onto dorsal border of lnternal condyle. (34) External distal 11gamental attachnent usually a produced, elongate, tubercle.

Tarsometatarsus.--(35) Hypotarsus with one closed calcaneal canal. (36) Inner calcaneal ridge extending about three-fourths the way down shaft as a sharp ridge. (37) Posterior shaft with spur core in male. (38) Trochlea for diglt II elevated above level of trochlea for digit IV. (39) Posterior metatarsal groove moderately excavated, w1th 1ts lateral margin swinglug abruptly onto posterlor face of shaft. (40) Nedial I1p of Internal cotyla weakly elevated, below level of intercotylar prominence. (4I) Intercotylar promlnence weakly produced.

Intermembral proport1ons.-.-(42) Ulna/humerus 97-100 per cent (Table 1). (43) Carpometacarpus/ulna 56 per cent. (44) Femur/t1blotarsus 58.65 per cent. (45) Tarsometatarsus/femur 110 per cent. (46) Tarsometatarsus/t1b1otarsus 61-72 per cent. (47) Ulna/femur 101-106 per cent. (48) UIna/t1blotarsus 61-70 per cent. (49) Carpometacarpus/ femur 58 per cent. (50) Katerlal lacking. (51) Illua/sternum 
$86-88$ per cent.

\section{Summary}

Varlable characters that are nelther assoclated with an evolutionary sequence nor are of any particular taxonomic use are omitted from the following paragraphs.

Rostrum.--The rostrum 18 long and shallow, slightly decurved, and without ornamentation in most Gall1. The Cracldae have the rostrum long, but deep and much compressed, and ornamented with a dorsal bony knob in Mitu and Crax. The Odontophorinae have the rostrum without ornamentation, but short, deep, and strongly decurved.

Sternum.--The sternum is an 1mportant element in the classification of galliform blrds. The sternum of the primative hoatzins of the suborder Opisthocomi is twonotched, and the sternal plate is wider posteriorly than anterlorly, whereas in the suborder Gall1 it 18 four-notched and the sternal plate is wider anterlorly than posteriorly. The superfamilies Cracoldea and Phasianoldea of the Gall1 are also separable on sternal characters. In the cracoldea the inner notches are less than half the length of the sternum and the sternal plate is only slightly narrower posteriorly than anterlorly, whereas in the Phasianoldea the Inner notches are much more than half the length of the sternum, and the sternal plate is much constricted posteriorly. The familles Magapodildae and Cracldae of the Cracoldea may 
be separated on the basis that the sternum is more than twice as long as 1ts Inner notch in the Magapodildae, and less than twice as long as its inner notch in the Cracidae (B1dgway and Friedmann, 1946).

A very large dorsal formen occurs on the manubrial spine in the Cracidae. This foramen is present, but only moderately large in the Numldidae, Catreus, Phaslanus, and Arguslanus of the Phaslaninae, and is obsolete in Pedloecetes of the Tetraonldae. The structure is absent in adults of the remalning Galli.

The anterlor lateral processes of the Cracldae are short, broad, and at right angles to the long axls of the sternum. In the Numldidae the anterlor lateral processes are short and broad, but make angles of about 45 degrees to the long axis of the sternum. In the other forms the anterlor lateral processes are long, slender, and parallel to the long axis of the sternum.

The anterior area of the sternal plate is highly pneumatic in the Cracldae, whereas it is only moderately pneumatic in the Numididae and Meleagrididae. In the , Phaslaninae the anterior sternal plate is moderately pneumatic in Gennaeus and Chrysolophus, but only slightly pneumat1c in the remalning forms. The Tetraonldae have the slightly pneumatic condition, whereas the Odontophorinae and Perdicinae have the anterior sternal plate non-pneumatic or only slightly pneumatic. 
Some noteworthy errors in Ridgway and Friedmann (1946) regarding the sternum of the Gall1 should be mentioned at this point. (1) The characters for separation of the superfamilles Cracoldea and Phaslanoldea are reversed (p. 4). (2) The characters "... outer divisions of the short, broad lateral process widely expanded teminally on both sides ...," and "... the episternal process perforated to recelve the feet of the coracolds..." (p. 5) are used to separate the superfamily Cracoldea from the Phaslanoldea. Nelther of the above characters are dlagnostic; the former is found in all members of the subfamily Gall1, whereas the latter character is found in all of the galliform birds.

Coracold.--The medial surface of the head is much flattened in the Meleagrididae, whereas it is rounded in the other Gall1.

The brachial tuberosity of the cracidae and the Meleagrididae is without the overhanging ventral portion found in the other Galli.

The dorsal intermuscular line is not raised distaily in the Cracidae, Meleagrididae, and most Phasianinae. It is slightly raised distally in the Numididae, Gallus and Chrysolophus of the Phasianinae, and sharply ralsed distally in the Tetraonidae, Perdicinae, and Odontophorinae.

The ventral interwuscular line terminates near the lateral end of the sternal facet in the cracidae, Meleagrididae, Acryll1um of the Numldidae, Lophophorus, 
Gennaeus, Chrysolophus, and Pavo of the Phasianinae, and Coturn1x of the Perdicinae. In Dendrortyx of the Odontophorinae the ventral interwuscular line terminates in the middle of the distal border of the sterno-coracoldal process, whereas in the remalning Gall1 it terminates at the t1p of the sterno-coracoldal process.

The distal dorsal face of the Cracldae, Meleagrididae, Phasianinae, and Tetraonldae has a large pneumatio fossa which is absent in the Odontophorinae and Perdicinae. The sterno-coracoldal process of the Cracidae and Dendrortyx of the Odontophorinae is without the terminal knob found in the other Gall1. In the Numldidae, Meleagrididae, Phasianinae, and in Philortyx of the Odontophorinae this knob is obsolete, whereas it is well developed in the remalning forms.

Scapula.--The ventral base of the glenold facet has a large pneumatic fossa in the Cracldae, and a small one in Arguslanus of the Phaslaninae. The other Gall1 lack this opening.

The area mediad to the glenold facet 18 without a depression in most Cracidae, in Numida of the Numldidae, the Meleagrididae, Tetraonldae, and most Phaslaninae. A depression is present in this area in Crax of the Cracidae, Acryll1um of the Num1didae, Lophophorus, Phaslanus, and Chrysolophus of the Phasianinae, the Odontophorinae, and in the Perdicinae. 
The brldge between the acromion process and glenold facet is excavated by a large pneumatic fossa in the Tetraonldae, and Pavo of the Phaslaninae, whereas this structure is lacking in the other forms.

The acromion process is straight in the Meleagrialdae, but deflected in the other Gall1.

The dorsal base of the shaft has a pneumatic fossa in the Meleagrididae, but 18 without this structure in the other forms.

The scapular blade 18 very short and wide in most Crac1dae, the Num1didae, the Meleagrididae, and Pavo of the Phasianinae. It is moderately short and wide in Ortal1s of the Cracidae, the Tetraonidae, and most Phagleninae. It 18 usually moderately elongate in the Perdiclnae, and 1s very elongate in Perdix of the Perdiclnae, and in the Oentophorinae.

The dorsal surface of the blade is shallowly concave in the Craclare, Num1didae, lieleagrididae, Tetraonidae, and Phaslaninae. It 1s flat, shallowly concave, or shallowly grooved in the Perdicinae, and deeply grooved throughout in the Odontophorinae.

The apex of the scapular blade is without terminal expansion in the Cracldae, fcrylilum of the Numididae, and Pavo of the Phaslaninae, whereas it is expanded terminally in the remalning Galli.

Humerus.--The pneumatic fossa is very small, and has an 
Inner shelf that extends from the medial bar to the internal bicipital surface in the Cracidae. The Numididae and Meleagrididae have this fossa small, but larger than in the Cracldae, and both the former families retain the inner shelf. In the Phasianinae and Tetraonidae the pneumatic fossa is moderately large. The inner shelf persists in all of the Phasianinae, but is present only in Bonasa of the Tetraonidae. In most Perdicinae, and in the Odontophorinae, the pneumat1c fossa 18 much enlarged, and an 1 neer shelf is present only in Perdix of the Perdlcinae, and Odontophorus gujanensis of the Odontophorinee.

The fossa II is absent in the Cracidae, obsolete in the Num1didae, Meleagrididae, Phaslaninae, and Tetraonldae, Perdix of the Perdiclnae, and Dendrortyx and Odontophorus of the Odontophorinae. It is weakly developed in Alectoris of the Perdicinae, and well developed in Coturnix of the Perdicinae, and in most Odontophorinae.

The blclpital crest has 1 ts lateral border truncated in Mitu of the Cracidae, and in the Numididae, whereas this structure is variously rounded in the other Galli.

UIna.--The external cotyla is weakly developed in the Cracidae, and only moderately developed in Numida of the Numididae. This structure is well developed in the other Gall1. The border of the external cotyla is truncated in the Meleagrididae and Argusianus of the Phasianinae. It is flattened dorsally in Crax globulosa of the Cracldae, and in 
Dendrortyx and Odontophorus guttatus of the Odontophorinae, whereas it is rounded in the other Gall1.

Carpometacarpus.--The p1siform process is obsolete and at the level of 1 ts 11 gamental attachment in the Cracidae, Acryllium of the Numldidae, the Tetraonidae, and most Perdicinke. It is produced medially and thus extends well beyond the level of 1 ts 11 gamental attachment 1n Num1da of the Ninldidae, the Meleagrididae, Phasianinae, Coturnix of the Perdicinae, and the Odontophorinae.

The 1ntermetacarpal tubercle is absent in the Numldidae, and represented only by a minute point in the cracidae. It is weakly developed in Pavo of the Phaslaninae, and Coturnix of the Perdiclnae. It is well developed and usually extends to the metacarpal III in the other Gall1.

The external $\mathrm{rim}$ of the carpal trochlea continues distad beyond the ligamental notch in the cracidae, whereas the $\mathrm{rim}$ ends at the 11gamental notch in the other Gall1.

Pelv1s.-.The pelvis is very wide and shallow in the Tetraonidae, whereas it is relatively narrow and deep in the other forms.

The pectineal process is obsolete in the Cracidae, Num1didae, Meleagrididae, Pavo cristatus of the Phasianinae, the Tetraonidae, and the Odontophorinae. It 18 well developed, long, and narrow in most Phasianinae, and in the Perdicinae. One or more pneumatic foramina occur on the pectineal process of the Cracidae, Meleagrididae, 
Phaslanlaae, Tetraonldae, and Dendrortyx of the Odontophorinae. In other Gall1 the pectineal process is non-pneumatic.

The anterior portion of the renal depression has a large preumat1c fossa in the Cracldae and Numididae. The other Gall1 lack a discrete fossa, but there are some pneumatic perforations in this area in most Phasianinae and in Bonasa of the Tetraonidae.

The renal bar is broad in most Cracldae, the Numldidae, Meleagrididae, Phaslaninae, Tetraonldae, most Perdicinae, and Phynchortyx, Cyrtonyx, Dactylortyx, and Odontophorus of the Odontophorinae. It is slender in Ortalis of the Cracldae, Coturnix of the Perdicinae, and in most Odontophorinae.

The renal bar has a pneumatic foramen in Arguslanus of the Phasianinae, most Tetraonidae, and the Perdclaae. It is w1thout this structure in Pedioecetes of the Tetraonidae and in the remalning Galil.

Femur.--The femur has apparently undergone less mod1flcation than many other skeletal elements of the Gall1.

The head of the femur is flattened, and has 1ts dorsal border at the level of the $111 a c$ facet in the Meleagrialdae, whereas the head $1 \mathrm{~s}$ swollen and has 1 ts dorsal border above the level of the 111 ac facet in the other Gall1.

The dorsal crest of the trochanter is very high in the Meleserididae, whereas it is low in the Cracldae, and several genera of the Odontophorinae. It 1 moderately 
h1gh in the other Gall1.

The area mediad to the anterlor border of the trochanter is without a pneumatic fossa in the Cracidae, Num1didae, Meleagrididae, Lophophorus and Gallus of the Phaslaninae, the Perdicinae, and the Odontophorinae. A pneumatic fossa occurs in this area in most Phasianinae and in the Tetraonidae.

Tiblotarsus.--The tiblotarsus 1s one of the less useful elements in the determination of relationships within the Gall1. This element shows little change in 1 ts basic structure, yet has much individual variation in minor characters.

The 1nner cnemial crest arises from the shaft well above the level of the outer cnemial crest in most ind1. viduals of the Meleagrididae, at the level of the outer cnemial crest in Num1da of the Num1didae, and Alectoris and Perdix of the Perdiclnee, and well below the level of the outer cnemial crest in the remalning forms.

The 1nternal distal 11 gamental attachment often extends onto the dorsal border of the internal condyle in the Mel eagrididae, but $1 \mathrm{t} 1 \mathrm{~s} \cdot \mathrm{w} 1 \mathrm{thin}$ the $11 \mathrm{mits}$ of the border of the internal condyle in the other forms.

The external distal ligamental attachment is usually a produced, elongate tubercle in the Meleagrididae, whereas this structure is obsolete in the other Galli.

Tarsometatarsus.-.The tarsometatarsus is the leg ele- 
ment most useful in analysis of evolutionary trends in the Gall1.

The hypotarsus usually has two roofed calcaneal canals in the Odontophorinae. Exceptions are Dendrortyx, Phynchortyx, and most specimens of Oreortyx, which have a ralugle roofed calcaneal canal. The rest of the Gall1 have only one roofed canal.

The laner calcaneal ridge of the Cracldae, Numldidae, Gallus of the Phasianidae, Lagopus of the Tetraonidae, Alectoris and Perdix of the Perdiclnae, and of the Odontophorinae is without the distal extension that extends one-half to two-thirds the way down the shaft in the other forms.

The posterior shaft has a spur core in the male of the Meleagrididae and Phaslanidae. The male of Alector 18 of the Perdiclnae has a rudimentary spur core, but this structure 1s lacking in the remalning Galli examined. Spur cores are sald to occur in the francolins.

The trochlea for a1git II is at the level of the trochlea for digit IV in the Cracidae, but it is elevated above the lezel of the trochlea for digit IV in the other Gall1. The posterior metatarsal groove 18 deeply excavated, w1th 1ts lateral margin swinging gently onto the posterior face of the shaft in the Cracldae, whereas it is moderately excavated, with its lateral margin swinging abruptly onto the posterior face of the shaft in the other forms. 
The medial $11 p$ of the internal cotyla 18 weakly elevated and below the level of the intercotylar prominence in the Cracidae and Meleagrididae, whereas it 18 elevated to the level of the intercotylar prominence in the other Gall1.

The intercotylar prominence is weakly produced in the Cracidae, but is well produced in tins other forms.

Intermembral ratios.--Numerical intermembral ratios of the Gall at the speciflc level are given in Table 1.

The carpometacarpus 18 half or less the length of the ulna in the Cracidae, whereas it is more than half the length of the ulna in the remalning Gall (w1th the exception of one speciuen of Acryl11um).

The femur is less than 70 per cent as long as the tiblotarsus in the Craclae, Acrylilum of the Numldidae, the Meleagrididae, and Arguslanus and Pavo of the Phaslaninae, but is more than 70 per cent the length of the femur. in the other forms.

The tarsometatarsus is over 90 per cent as long as the femur in the Cracidae, Acryllium of the Numldidae, tho Meleagrid1dae, and Gennaeus, Gallus, Arguslanus and Pavo of the Phasianinae, but is less than 90 per cent the length of the femur in the other Gall1.

The ulna is longer than the femur in the cracidae, Acryllium of the Num1didae, the Meleagrididae, and Arguslanus and Pavo of the Phasianinae. It is shorter than the femur in the other Galli. 
Relationsh1ps of Taxa

of the Gall1 studied in the present work, the Cracidae have been considered to be most primative by the majority of authors. The recent work of Hudson, Lanz11lott11, and Edwards (1959) on the pelvic $11 \mathrm{mb}$ musculature in galliform birds tends to confirm this view. The arrangement of the families in the classification presented below is based largely upon several trends in the Phaslanoldea towards modiflcation of skeletal structures found in the cracidae. These trends are summarized in the section on evolutionary trends. On the basis of osteology it is suggested that the classification of the suborder Gall1 be modified in the following manner:

Wetmore's classification

Superfamily Cracoldea

Fam1ly Megapod11dae

Family Cracidae Superfamily Phaslanoldea

Famlly Tetraonldae

Fam1ly Phaslanidae

Family Numldidae

Fam1ly Meleagrididae
Proposed classification

Superfamlly Cracoldea Family Megapodi1dae Famlly Cracidae Superfamily Phaslanoldea Family Numididae Fam1ly Meleagrididae Family Phaslanldae Fam1ly Tetraonldae Fam1ly Odontophoridae

The above changes include placing the Num1didae and Meleagrididae nearer the Cracidae, to which they show skeletal relationships as well as to each other. The Tetraonldae are placed in a higher position than the Phasianidae, which show more relationships with the Cracidae, Num1didae, and Meleagrididae in several osteological characters. The New 
World quall are recognized as a separate family the Odontophoridae, rather than a subfamily of the Phasianidae, and are thought to be the most highly evolved group of the Gell1. The systematic status of the 01d World quall of the subfamlly Perdiclnae 1s doubtful, but they are here included w1th the Phasianidae.

Osteological characters indicate that the groups recognized in the present paper as famll1es represent natural divisions (with the possible exception of the Phasianidae), but it should be polnted out that several authors, especially sibley (1960), belleve that there is taxonomic Inflation in galliform classiflcation, and that the familles of Phaslanoldea recogalzed by wetmore might better be treated as subfam1lies

\section{Evolutionary Trends}

(1) Beduction and loss of the dorsal foramen in the manubrial spine of the sternum: Cracldae (foramen very large), Numidiae (foramen moderately large), Phasianidae (foramen moderately large or absent), Tetraonldae (foramen obsolete or absent), Meleagr1a1dre and Odontophoridae (fora. men absent).

(2) Modifleation of the anterlor lateral processes of the sternum: Cracldae (processes short, broad, at right angles to long axis of sternum), Numididae (processes short, broad, at 45 degree angles to long axis of sternum), 
Meleagr1d1dae, Phaslanlaae, Tetraon1dae, Odontophor1dae (processes long, nerrow, parallel to long axis of sternum).

(3) Decreas 1ng pneumat1c1ty of anterior sternal plate: Cracidae (plate highly pneumat1c), Numldidae and Meleagrididae (plate moderately pneumat1c), Phaslenldae (plate moderately, slightly, or non-pneumat1c), Tetraonidae (plate slightly pneumat1c), Odontophoridae (plate slightly or non-pneumat1c).

(4) Development of an overhang1ng ventral portion of the brachlal tuberosity of the coracold: Cracidae and Meleagrididae (cverhang1ng ventral port1on absent), Num1didae, Phaslanidae, Tetraonldae, Odontophorldae (overhang1ng ventral portion present).

(5) Development of a sharply raised distal portion of the dorsal 1ntermuscular Ine of the coracold: Cracidae and Meleagrididae (11ne without sharply ralsed distal portion), Phaslanidae (11ne usually w1thout sharply ralsed distal portion, but way be slightly or sharply ralsed distally), Num1didae (11be slightly ralsed distally), Tetreonldae and Odontophorldae (line sharply ralsed distally).

(6) Shifting position of termination of ventral intermuscular I1ne of coracold: Cracldae and Meleagrididae (IIne terminates near lateral end of sternal facet), Phaslanldae (11ne usually teralnates near lateral end of sternal facet, occasionally at tip of sterno-coracoldal process), Numldidae (11ne terminates near lateral end of sternal facet or at tip of aterno-coracoldal process), Odontophorldae (IIne usually 
terminates at tip of sterno-coracoldal process, occaslonally at midale of distal border of sterno-coracoldal process), Tetraonldae (I1ne terwinates, Et tip of sterno-coracoldal process).

(7) Development of a terminal knob on the sterno-coracoldal process of the coracold: Cracldae (process w1thout terminal knob), Numidiae and Meleagrididae (process with a very small terwlal knob), Phaslanidee (process usually with a very small terminal kmob, occaslonally with a well developed terminal knob), Odontophoridae (process usually with a well developed terminal knob, occaslonally with terminal knob very small or absent), Tetraonidae (process with a well developed terminal knob).

(8) Change in the shape of the scapular blade: Numididae and Meleagrididae (blade very short and w1de, shallowly concave dorsally), Cracldae (blade usually very short and wlde, occasionally moderately elongate, shallowly concave dorsally), Phaslanidae (blade usually moderately elongate, occaslonally very short and wide or very elongate, usually shallowly concave dorsally, occaslonally flat or shallowly grooved), Tetraonldae (blade moderately elongate, shallowly concave dorsally), Odontophorldae (blade very elongate, deeply grooved dorsally).

(9) Increasing pneumaticlty of the proximal end of the humerus 2ncluding enlargenent of the pneuratic fossa, obliteration of 1 ts 1 nner shelf, and develooment of fossa II: 
Cracidae (pneumatic fossa very small; inner shelf present; fossa II absent), Numididae and Meleagrididae (pneumatic fossa small; Inner shelf present; fossa II 1ndistinct), Tetraonidae (pneumatic fOssa moderately enlarged; usually without, occasionally with inner shelf; fossa II indistinct), Phasianidae (pneumatic fossa usually moderately large, occasionally much enlarged; usually with, occaslonally without inner shelf; fossa II usually lndistinct, occasionally well developed), Odontophoridae (pneumatic fossa much enlarged; usually w1thout inner shelf, occasionally w1th lnner shelf; fossa II usually well developed, occaslonally indistinct).

(10) Enlargement of the p1siform process on the carpometacarpus: Cracidae and Tetraonidae (process 1ndistinct), Numididae (process lndistinot or produced medially), Phaslánlcee (process usually produced medially, occaslonally 1ndistinct), Meleagrididae and Odontophoridae (process produced medially).

(11) Loss or enlargement of intermetacarpal tubercle of carpometacarpus: Cracidae (tubercle a minute point), Numididae (tubercle absent), Phasianidae (tubercle usually well developed, occaslonally weakly developed), Meleagrididae, Phaslanldae, Tetraonldae, and Odontophorldae (tubercle well developed).

(12) Loss of pneumaticity of anterior portion of renal depression of pelvis: Cracidae and Numididae (depression 
w1th large pneumat1c fossa), Phaslan1dae (depression usually w1th pneumat1c foramina, occasionally non-pneumat1c), Tetraonldae (depression usually non-pneumat1c, occaslonally w1th pneumatic foramina), Meleagrididae and Odontophor1dae (renal depression non-pneumatic).

(13) Development of a distal extension of inner calcaneal rldge, and spur core on posterlor shaft of tarsometatarsus: Cracidae, Num1didae, and Odontophorldae (ridge w1thout distal extension; shaft w1 thout spur core), Tetraonldae (ridge usually with, occasionally without, distal extension; shaft without spur core), Phasteridale (rldge usually w1th, occaslonally w1thout; distal extension; shaft usually with spur core in the male, occaslonally with rudimentary spur core or without spur core), Meleagrididae (rlage with distal extension; shaft with spur core in the male).

Among the above characterg, the Meleagrididae show the primitive condition in four instances, the Numldidee in three Instances, and the Tetráonldae, and Odontophor1dae in only one 1nstance. The Phasianidae do not show the prim1t1ve condition. The Phaslanidae are intermediate in all characters, the Numldidae in nine, the Tetraonidae in $81 x$, the Meleagrididae in three, and the odontophoridae in two. The Odontophoridae show the advanced condition in 10 Instances, the Tetraonldae and Meleagrididae $1 n s 1 \mathrm{x}$ Instances, the Phaslanidae in three Instances, and the 
Num1dida only once. Thus the New World quall appear to represent a highly specialized, possibiy the most highly evolved group within the Galli.

It should be pointed out here that a very interesting parallel in the trend towards enlergement of the pneumatic fossa and fossa II of the humerus is found in the Passer1formes (Ashley, 1941). The main difference in the trend in the Passeriformes and in the Galli is that the former group. has progressed much farther. In the most highly evolved passerines the medial bar has become so eroded that the two fossae become continuous distally below the remant of the bar.

Status of the Odontophoridae and Phasianidae.--There has been much criticlsm of the taxonomic status of the Phasianidae of Wetmore. Delacour (1951) polnts out that the pheasants are "a group of game birds which do not differ from others by very well-defined or 1mportant characterist1cs." S1bley (1960) remarks that "The inciusion of qualis, partridges, and francolins in the subfamily makes it a diverse group which is exceedingly difficult to define," and on the basis of electrophoretic patterns of egz-white protelns belleves that the New World quall may represent a separate subfamily. The status of the old World quall of the subfamlly Perdicinae is less clear. The Perdicinae skuw on one hand basic resemblances to the pheasants, but on the other hand some of the same trends in modification of skeletal 
structures found in the New World que1l, possibly through parallel evolution in the old and New World b1rds. The Perdicinae are here retalned as a subfamlly of the Phaslanldae, although this greatly increases the osteolog1cal heterogenelty of the famliy. Skeletal characters that separate the Odontophoridae (New World quall) from the Phaslanldae (Old World quall and pheasants) 1nclude the following:

In the rostrum, (1) Odontophor1dae, rostrum short, deep, and strongly decurved; Phaslanldae, rostrum long, shallow, and slightly decurved.

In the sternum, (1) Odontophoridae, manubrial aplne w1 thout dorsal foramen, Phaslanldae, manubrial splne often with dorsal foramen.

In the coracold, (1) Odontophorldae, dorsal 1ntermuscular line sharply ralsed alstally; Phaslanldae, dorsal laternuscular 11ne usually not raised, or only slightly ralsed distally. (2) Odontophorldae, ventral intermuscular line terminating at tip of sterno-coracoldal process or occasionaliz in widale of distal border of sternal facet; Phaslanldae, ventral intermuscular line of ten terrinating near lateral end of sternal facet. (3) Odontophorlaae, distal dorsal face non-pneumat1c; Phaslanldae, distal dorsal face usually with a large pneumatic fossa. (4) Odontophorldae, sterno-coracoldal process usually term1nating in a well developed terminal knob; Phaslanidae, 
sterno-coracoldal process usually terminating in an obsolete terminal knob.

In the scapula, (1) Odontophoridae, scapular blade very elongate, w1th 1 ts dorsal surface deeply grooved throughout, and with 1 ts apex expanding terminally; Phasianidae, scapular blade w1th much variation in shape, but never as in Odontophor1dae.

In the humerus, (1) Odontophoridae, pneumat1c fossa much enlarged with Inner shelf only in one specles of Odontophorus; Phasianlaae, pneumat1c fossa usually moderately large, usually with inner shelf extending from medial ber to Internal blolp1tel surface. (2) Odontophorldae, rossa II usually well developed; Fhaslanldae, fossa II usually obsolete.

In the pelvis, (1) Odontophoridae, pectineal process obsolete; Phaslanldae, pectineal process well developed, long, and nerrow (Pavo cristatus 18 alngle exception, and has the pectineal process obsolete, whereas it is well developed, long, and narrow in Paro mut1cus). (2) Odontophor1dae, renal bar non-pneumatic; Phaslanldae, renal bar often with pasumatic Soramen.

In the tarsometatarsus, (1) Odontophoridae, hypotarsus usually w1th two closed calcaneal canals; Phaslanidae, hypotarsus w1th one olosed calcaneal canal. (2) Odontophoridae, lnber calcaneal ridge without distal extension; Phaslanidae, laner calcaneal ridge usually with distal extension that 
extends two-thirds the way down the shaft.

(3) Odontophoridee, posterior shaft without spur core: Phaslanidae, posterior shaft usually with spur core, or rudimentary spur core in the male. 


\section{OSTEOLOGY OF LIVING NEW WORLD QUAIL}

Osteological evidence presented in the previous section Indicates that the New World quall represent a natural and highly evolved group of galliform birds that should be recogn1zed as a fam11y, the odontophoridae, rather than as a subfamily of the Phasianidae.

The next phase of the present work lacludes an osteologlcal account of the living genera and specles of New World quall avallable for study, as well as remarks on skeletal variation in some subspeoles of Collnus virginianus. Th1s section was undertaken w1th two purposes in mind, namely: (1) to clarify the relatlonshlps of the Recent forms, and (2) to become acqualnted with skeietal variation at the gener1c, spec1f1c, and subspec1flc level in Becent forms, before attempt1ng to deal with the foss1l material.

The skeletal elements studied for the following account are the same as those in the preceding section, and are those bones most frequently found as foss118.

\section{Dendrortyx Gould 1844}

Thts genus Includes four 11v1ng spec1es, conflned to the mountalns of Mexico and Central America. Only a single skeleton of Dendrortyx leucophrys (Gould 1844) was ava1la- 
ble. Its measurements are given in Table 7 .

Rostrum.--(1) Belatively long and shallow. (2) Nasal fossae elliptical.

Sternum.--(3) Helght of carina through sternal plate 30 per cent length of sternum (Table 3). (4) Dorsal 11p of coracoldal sulcus projected well beyond ventral 11p. (5) Depressions on snterior portion of sternal plate shallow and slightly pneumatic. (6) Base of posterlor lateral process more than one-half width of sternal plate at 1 ts m1dale.

Coreco1d.--(7) Ent1re proximal end bending ventrad above level of procoracold process. (8) Head broadly rounded, much depressed, and much inflected. (9) Brachlal tuberosity w1th moderate dorsal, but slight ventral overhang. (10) Furcular facet weakly inflated. (11) Blclpital attachment well developed, with margin between 1t and head concave. (12) Shaft narrow proximally, with distal portion of 1 ts ventral surface convex medially. (13) Procoracold process w1th 1 ts apex rounded. (14) Dorsal intermuscular line swinglng out to lateral border of shaft, with distal fifth sharply raised. (15) Ventral Intermuscular line terminating in middle of distal border of sterno-coracoldal process. (16) Dorsal face weakly excavated, distally, but with distinct round, deep, forsa below tubercle for $1.1 \mathrm{ga}$ mentum sterno-curacoldeum dorsale, and above external end of sternal, facet. (17) Tubercle for 11gamentum sterno-cora. 
coldeum dorsale obsolete, but rounded. (18) Internal distal angle without distinct tubercle or ridge on dorsal face. (19) Sterno-coracoldal process with distal margin strongly oblique, not produced as a sharply ralsed ridge, but grooved dorsally; with 1ts tip directed proximally, but without a terminal knob. (20) D1stal border of sternal facet very shallowly concere.

Scapula.--(21) Glenold facet elliptical in dorsal view. (22) Dorsal depression just mediad to glenold facet deeply excavated. (23) Brlage between acromlon process and glenold facet about one-half w1ath of glenold facet. (24) Acromion process with its apex acute and slightly derlected.

Humerus.-- (25) Pneumat1c fossa a short oval, w1 thout Inner shelf. (26) Median crest strongly developed, elevated throughout. (27) Capltal groove deeply excavated, with 1ts internal margin strongly elevated. (28) Margin between head and Internal tuberosity only slightly concave. (29) Head about as long as broad in anconal view. (30) Blage along medial border of fossa II slightly swollen, elongate, and w1th 1 ts apex acute. (31) Fossa II obsolete. (32) Lat1ss1mus rlage (Ashley, 1941) extending along lateral edge of shaft throughout its length. (33) External tuberosity moderately inflated. (34) Blololtal crest arising gently from shaft, roundod, and with its distal border lacking a groove. (35) Deltold crest strongly developed, much 
Inflected, and w1th 1ts summit knob-like. (36) Enteplcondyle at level of Internal condyle. (37) Enteplcondylar prominence weakly produced, with 1 ts p1t placed on internal face. (38) Depression of $M$. brachlal1s ant1cus deeply excavated. (39) D1stal border of external condyle flat in anconal vlew. Ulne.-. (40) Olecrenon process strongly produced, and w1th 1ts apex rounded. (41) External cotyla shortened, flattened dorsally, with 1ts distal border sloping preclpitously 1nto shaft, and deeply notched by proximal radial 1mpression. (42) Impression for M. brach1alls ant1cus exca_ vated, with 1 ts borders distinct. (43) Helght at middle of shaft 83 per cent of helght just alstal to external cotyla (Table 4). (44) Distal radial impression well excavated. (45) Notch between carpal tuberosity and internal condyle weak. (46) External condyle weakly produced, ar1s1ng abruptly from shaft, and w1th 1ts ventral border elattened. Carpometacarpus.--(47) Metacarpal I moderately polnted terminally. (48) Rldge separating anterlor carpal fossa from excavated area above plsiform process very weak, and extending only slightly onto base of metacarpal I. (49) P1siform process round in internal $\nabla 1$ ew, much reflected dorsad, thus produced well above dorsal $\mathrm{rim}$ of Inner carpal trochlea. (50) L1gamental attachment of plsiform process produced throughout, moderately swollen prozimally and distally, with proximal portion separeted from pisiform process by shallow sulcus. (51) Internal carpal trochlea with 
1ts proximal border shallowly concave, and 1 ts ventral border slightly notched. (52) Intermetacarpal tubercle extending to and ankylosing w1th metacarpal III, and distally placed W1th a small space between 1 ts posterior border and Junction of metacarpals II and III. (53) Tubercle on 1nternal proximal face of metacarpal. III obsolete. (54) W1th one moderately developed and one obsolete tubercle on external proximal face of metacarpal III. (55) Metacarpal III moderately bowed.

Pelv1s.--(56) W1ath of pelvis through antitrochanters 51 per cent length of 1 nnominate from anterior edge of 111 um to 1schlal angle (Table 3). (57) Pectineal process obsolete, only moderately produced beyond acetabular border, and w1th 1 ts apex rounded. (58) Depression on medial slde of pecti. neal process deeply excavated, and perforated by a foramen. (59) Posterior $111 a c$ crest w1thout prominence. (60) Bldge orlginating on posterior 111ac crest at level of 1110-1schiac fenestra, and contlnuing ventrad and posterlad towards posterior border of 111um w1th prominence sharply arlsing from 1ts posterior portion. (61) Dorsal face of post-acetabular llium moderately broad anterlad, narrowing abruptly posterlad to form acute apex of short, broad, dorsal roof of posterlor process. (62) Caudal face of post-acetabular lilum enlarged, triangular, and vertical in position, with 1 ts posterodorsal apex forming posteromedial wall of posterior process. (63) Lateral face of post_acetabular 
1lium with 1 ts posterodorsal apex acute, and forming shortened lateral wall of posterlor process. (64) Renal bar very slender, w1th both bar and posterlor process excavated by renal depression. (65) Ischlum at angle of about 160 degrees to ventral edge of posterior 111 ac crest. (66) W1ath through transverse processes of fourth synsacral vertebra 55 per cent of length of synsacrum from centrum of flrst synsacral vertebra through transverse process of fourth synsacral vertebra.

Femur.--(67) D1stal w1dth 17 per cent length (Table 5). (68) Head moderately enlarged, bent dorsally, and rotated posterlorly. (69) Neck long. (70) Illac facet compressed, w1th posterior border stralght. (71) Dorsal crest of trochanter depressed and deflected, with 1 ts dorsal border rlat. (72) Trochanterlc rldge 20 per cent length of semur. (73) D1stal depth 85 per cent of d1stal w1ath. (74) Internal condyle moderately w1de, and with 1 ts anterlor border much produced throughout. (75) External condyle depressed, and flattened anterlorly.

T1blotarsus.-- (76) Depth of Inner cnemlal crest 59 per cent of 1ts length (Table 4). (77) Outer cnemial crest decurved. (78) Interartlcular tubercle moderately produced. (79) Area between external articular surface and outer cnemial crest moderately concave in dorsal, view. (80) Posterior margin between external and internal articular surfaces weakly notched. (81) Area just anterior to rlage from proxi. 
mal Internal IIgamental attachment w1th deeply excavated depression. (82) Internal I1gamental prominence on Internal condyle strongly produced. (83) Face of Intemal condyle well excavated, with 1 ts border highly elevated. (84) Dorsal border of supratendinal bridge oblique.

Tarsometatarsus.--(85) Distal width 14 per cent of length (Table 6). (86) Proximal depth 94 per cent of prox1mal w1dth. (87) Intercotylar prominence moderately deflected, and w1th 1ts apex polnted. (88) Posterlor intercotylar area moderately excavated as a triangular depression. (89) Area surrounding posterior opening of inner proximal foramen deeply excavated. (90) Hypotarsus with two well developed and one obsolete calcaneal ridges, two calcaneal grooves, and one closed calcaneal canal. (91) Anterlor face of shaft extensively excavated by anterior metatarsal groove. (92) Depth of middle trochlea 56 per cent of distal width. (93) Trochlea for diglt II only slightly inflected. (94) Wing of trochlee for digit IV depressed anteroposterioriy, thus entire trochlea slightly longer than deep. Intermembral proportions.-- (95) W1ng/leg 52 per cent (Table 2). (96) Ulna/humerus 88 per cent. (97) Tarsometatarsus/femur 88 per cent. (98) Tarsometatarsus/t1b1otarsus 63 per cent. (99) Humerus/femur 71 per cent. (100) Humerus/t1b1otarsus 51 per cent., (101) U1na/femur 63 per cent. (102) UIna/tiblotarsus 45 per cent. (103) UIna/ tarsometatarsus 72 per cent. (104) Carpometacarpus/femur 37 
per cent. (105) Carpometacarpus/t1blotarsus 27 per cent. (106) Carpometacarpus/tarsometatarsus 42 per cent. (107) Tarsometatarsus/humerus 124 per cent. (108) Ilium/ sternum 89 per cent. (109) Helght of sternal carina/111um 34 per cent.

\section{Phllortyx Gould 1846}

Th1s monotyple genus is conflned to the mountalns of Mexico. Measurements of Ph1lortyx fasclatus (Could 1844) are given in Table 7 .

Bostrum..--(1) Eelat1vely long and shallow. (2) Nasal fossee elliptical.

Sternum--- (3) Sternum incomplete. (4) Dorsal 11p of coracoldal aulcus projected well bejond ventral 11p. (5) Depressions on anterior portion of sternal plate deep and slightly pneumatic. (6) Base of posterlor lateral process less than one-half width of sternal plate at 1ts midale.

Coraco1d.--(7) Entire proximal end stralght above procoracold process.

(8) Head polnted, much compressed, and much reflected. (9) Brachial tuberosity obsolete dorsally, but with woderate rentral overhang. (10) Furcular facet weakly inflated. (11) Blolpltal attachment well developed, with margin between it and head concave. (12) Shaft wide proximally, with distal portion of 1 ts ventral surface concave medially. (13) Procoracold process w1th 1ts apex acute. 
(14) Dorsal 1ntermuscular 11ne swinglag out to mediel surface of shaft, with alstal helf sherply ralsed. (15) Ventral intermuscular line terminating at tip of sterno-coracoldal process. (16) Dorsal face weakly excavated distally, and w1 thout fossa. (17) Tubercle for 11 gamentum sterno-sora. coldeum dorsale well developed, and rounded. (18) Internal distal angle with distinct dorsal ridge extending obliquely to above lateral end of sternal facet. (19) Sterno-cora. coldel procese with distal margin moderately oblique, not produced as a sharply raised ridge, and w1thout dorsal groove; with 1 ts tip directed laterally, and ending in an obsolete terminal knob. (20) D1stal border of sternal facet shallowly conceve.

Scapula.-- (21) Gleno1d facet oval in dorsal view. (22) Dorsal depression Just med1ad to glenold facet shal. lowly excavated. (23) Brldge between acromlon process and glenold facet about one-third width of glenold facet. (24) Acromion process with 1 ts apex rounded and moderately derlected.

Fumerus.-- (25) Pneumat1c fossa a moderately long ell1pse, w1thout 1nner shelf. (26) Median crost weakly developed, but elevated throughout. (27) Cap1tal groove deeply excavated, w1th 1 ts 1 aternal marg1n strongly elerated. (28) Margin between head and internal tuberosity moderately concave. (29) Head about as long as broad in anconal view. (30) Rldge along medial border of fossa II 
slightly swollen, elongate, and with 1ts apex acute. (31) Fossa II well developed. (32) Lat1ssimus ridge orig1nating on lateral edge of shaft, but swinging in onto anconal face proximally. (33) External tuberosity moderately 1nflated. (34) Blcipital crest arising gently from shaft, polnted, and with 1 ts distal border lacking a groove. (35) Deltold crest moderately developed, slightly inflected, and with its summit knob-like. (36) Enteplcondyle produced slightly beyond level of Internal condyle. (37) Enteplcondylar prominence moderately produced, w1th 1ts p1t placed on 1nternal face. (38) Depression for M. brachlal1s anticus deeply excavated. (39) D1stal border of external condyle rounded in anconal. view.

Ulna.--(40) Olecranon process strongly produced, and with 1 ts apex polnted. (4I) External cotyla moderately elongate, rounded throughout, with 1 ts distal border sloping gently 1nto shaft, and deeply notched by proximal radial 1mpression. (42) Impression for M. brachialis anticus represented by an unexcavated scar, w1th 1 ts borders 1ndstinct. (43) Helght at midale of shaft 85 per cent of helght just distal to external cotyla (Table 4) (44) D1stal radial 1mpression obsolete. (45) Notch between carpal tuberosity and Internal condyle well developed. (46) External condyle well produced, arising abruptly from shaft, and with its ventral border flattened.

Carpometacarpus.--(47) Metacarpal I moderately polnted 
terminally. (48) Bldge separating anterior carpal fossa from excavated area above plsiform process produced, and extends well onto base of metacarpal I. (49) P1siform process round in internal view, moderately reflected dorsad, thus produced slightly above dorsal rim of Inner carpal trochlea. (50) Ligamental attachment of plsiform process produced and moderately swollen proximally, flattened distally, with proximal portion connected to plsiform process by bony bridge. (51) Internal carpal trochlea w1th 1 ts proximal border shallowly concave, and its ventral border w1 thout notch. (52) Intermetacarpal tubercle extending slightly beyond, but not ankylosing with metacarpal III, and distally placed w1th a small space between 1ts posterior border and Junction of metacarpals II and III. (53) Tubercle on internal proximal face of metacarpal III elongate and weakly produced. (54) WIth only one moderately developed tubercle on external proximal face of metacarpal III. (55) Metacarpal III slightly bowed.

Pelv1s.-- (56) w1dth of pelv1s through antitrochanters 47 per cent length of 1nnominate from anterlor edge of 111 um to 1schial angle (Table 3). (57) Pectineal process obsolete, only moderately produced beyond acetabular border, and w1th 1ts apex pointed. (58) Depression on medial side of pectineal process deeply excavated, but without foramen. (59) Posterior 111 ac crest w1 thout prominence. (60) R1dge originating on posterior 111ac crest at level of 1110- 
1schiac fenestra, and continuing ventrad and posteriad towards posterior border of 111 um with prominence sharply arising from its posterior portion. (61) Dorsal face of post_acetabular ilium moderately broad anterlad, narrowing abruptly posterlad to forw acute apex of short, broad, dorsal roof of posterior process. (62) Caudal face of post_acetabular 1lium enlarged, triangular, and vertical in position, with 1ts posterodorsal apex forming posteromedial wall of posterior process. (63) Lateral face of post-acetabular llium with 1 ts posterodorsal apex acute, and forming shortened lateral wall of posterior process. (64) Benal bar moderately slender, with both bar and posterior process excavated by renal depression. (65) Ischium at angle of about 160 degrees to ventral edge of posterior 111ac crest. (66) Width through transverse process of fourth synsacral vertebre 60 per cent of length of synsacrum from centrum of first synsacral vertebra through transverse process of fourth synsacral vertebra (Table 3 ).

Femur.-. (67) Distal width 14 per cent of length (Table 5). (68) Head moderately enlarged nelther bent dorsally nor rotated posteriorly. (69) Neck only moderately long. (70) Illac facet without compression, w1 th posterior border convex. (71) Dorsal crest of trochanter compressed and reflected, with 1 ts dorsal border rounded. (72) Trochanteric ridge 27 per cent length of femur. (73) D1stal depth 97 per cent of alstal width. (74) Internal condyle 
very w1de, and w1th 1 ts anterlor border moderately produced throughout. (75) External condyle compressed and rounded suteriorly.

T1blotarsu8.--(76) Depth of 1nner cnemial crest about 45 per cent of 1 ts length (Table 4). (77) outer cnemlal crest decurved. (78) Interartlcular tubercle weakly produced. (79) Area between external articular surface and outer cnemlal crest moderately concave in dorsal view. (80) Posterlor margln between external and Internal articular surface w1th a distinct notch. (81) Area just anterior to ridge from proximal internal 11gamental attachment W1thout deeply excavated depress1on. (82) Internal 11ga_ mental prominence on internal condyle moderately produced. (83) Face of internal condyle moderately excarated, with Its border moderately elevated. (84) Dorsal border of supratendinal bridge stralght.

Tarsometatarsus.--(85) D1stal width 17 per cent of length (Table 6). (86) Proximal depth 86 per cent of prox1mal width. (87) Intercotylar prominence much deflected, and with its apex pointed. (88) Posterior Intercotylar area weakly excavated as a triangular depression. (89) Area surrounding posterior opening of inner proximal foramen deeply excavated. (90) Hypotarsus with two well developed and one obsolete calcaneal rlages, two calcaneal grooves, and two closed calcaneal canals. (91) Anterlor face of shaft extensively excavated by anterior metatarsal groove. 
(92) Depth of middle trochlea 59 per cent of distal w1ath.

(93) Trochlea for diglt II only slightly inrlected.

(94) WIng of troohlea for diglt IV depressed dorsoventrally, thus ent1re trochlea wuch deeper than long. Internembral proportions.-- (95) W1ag/leg 65 per cent (Table 2). (96) Ulna/humerus 87 per cent. (97) Tarsometatarsus/femur 76 per cent. (98) Tarsometatarsus/t1blotarsus 59 per cent. (99) Humerus/femur 82 per cent. (100) Humerus/t1blotarsus 64 per cent. (101) Ulna/femur 72 per cent. (102) Ulna/t1blotarsus 55 per cent. (103) Ulna/tarsolsetatarsus 94 per cent. (104) Carpometacarpus/femur 44 per cent. (105) Carpometacarpus/t1biotarsus 34 per cent. (106) Carpometacarpus/tarsometatarsus 58 per cent. (107) Tarsometatarsus/humerus 93 per cent. (108) Il1um/ sternum 41 per cent. (109) Helght of sternel carina/111um 41 per cent.

Oreortyx Baird 1858

The monotyple genus Oreortyx occurs from hashington to northern Baja, Callforn1a. Measurements of 0. pleta (Douglas 1829) are given in Table 7.

Rostrum.--(1) Relatively long and shallow. (2) Nasal fossae ell1ptioal.

Sternum.-- (3) Helght of carlna through sternal plate 29-3i per cent length of sternum (Table 3). (4) Dorsal 11p of coracoldal sulcus projected well beyond ventral 11p. 
(5) Depressions on anterior portion of sternal plate deep and moderately pueunatic. (6) Base of posterior lateral process less than one-half width of sternal plate at 1ts mldale.

Coracold.-- (7) Entire proximal end stralght above procoracold process. (8) Head broadly rounded, moderately depressed, and moderately reflected. (9) Brachlal tuberosity with 811 ght dorsal and ventral overhang. (10) Furcular facet moderately inflated. (11) BLc1pital attachment well developed, w1th margin between 1t and head concave. (12) Shaft wide proximally, with distal portion of 1 ts ventral surface concave medilly. (13) 'Frocoracold process w1th 1 ts apex rounded. (14) Dorsal 1ntermuscular I1ne swinglng out to medial surface of shaft, with distal half sharply ra1sed. (15) Ventral intermuscular Iine term1nat1ng at t1p of sterno-coracoldal process. (16) Dorsal face weakly excavated distally, and without fossa.

(17) Tubercle for 11 gementum stemo-coracoldeum dorsale well developed, but irregular in outline. (18) Internal distal angle w1th distinct irregular tubercle extending obliquely to above lateral end of sternal facet. (19) Sterno-coracoldal process with distal margin slightly oblique, not produced as a sharply ralsed ridge, and w1 thout dorsal grooves with its tip directed lateraliy, and ending in a terminal knob. (20) Distal border of sternal facet deeply concave. Scapula.--(21) Glenold facet oval in dorsal view. 
(22) Dorsal depression just mediad to glenold facet shallowly to moderately excavated. (23) Bridge between acromion process and glenold facet about one-half width of glenold facet. (24) Acromion process with 1 ts apex acute and slightly deflected.

Humerus.-- (25) Paeumat1c fossa a moderately long oval or ovalo1d, w1 thout 1nner shelf. (26) Median crest strongly developed, elevated only at 1 ts middle. (27) Capital groove moderately excavated, with 1ts internal margin moderately elevated. (28) Margin between head and Internal tuberosity moderately concave. (29) Head broader than long in anconal view. (30) Rldge along medial border of fossa II much swollen, elongate, and w1th 1 ts apex acute. (31) Fossa II well developed. (32) Lat1ss1mus ridge orlglnating on lateral edge of shaft, but swinglng in onto anconal face proximally. (33) External tuberosity much 1nrlated. (34) B1c1pital crest arlsing gently from shaft, pointed, and w1th 1 ts distal border lacking a groove. (35) Deltold crest moderately developed, silghtly inflected, and with 1 ts summit knob-l1ke. (36) Enteplcondyle at level of 1nternal condyle. (37) Enteplcondylar prominence moderately produced, w1th 1 ts pit placed on Internal face. (38) Depression of M. brachlalis antlcus shallowly excavated. (39) D1stal border of external condyle rounded in anconal view. Ulna.--(40) Olecranon process strongly produced, with 1ts apex polnted. (4I) External cotyla much elongated, 
rounded throughout, w1th 1 ts distal border sloping gently Into shaft and, only slightly notched by proximal radial 1mpression. (42) Impression for M. brachlalls antlcus excavated, with 1 ts borders distinct. (43) Helght at midale of shaft 64-70 per cent of helght just distal to external cotyla (Table 4). (44) D1stal radial impression obsolete. (45) Notch between carpal tuberosity and internal condyle well developed. (46) External condyle moderately produced, arlsing gently from shaft, and rounded throughout.

Carpometacarpus.--(47) Metacarpal I sharply polnted terminally. (48) Ridge separating anterlor carpal fossa from excavated area above plsiform process produced, and extends well onto base of metacarpal I. (49) P1siform process ovalo1d in Internal view, slightly reflected dorsad, thus below level of dorsal rim of inner carpal trochlea. (50) Ligamental attachment of plsiform process produced and wuch swollen proximally, flattened distally, with proximal portion connected to p1siform process by bony bridge. (51) Internal carpal trochlea w1th 1 ts proximal border a1stinctly concave, and 1ts ventral border slightly notched. (52) Intermetacarpal tubercle extending slightly beyond, but not ankylosing with metacarpal III, and distally placed w1th a smáll space between 1 ts posterlor border and junction of metacarpals II and III. (53) Tubercle on Internal proximal face of metacarpal III elongate and moderately produced. (54) w1th one strongly developed tubercle on external proxi- 
mal face of metacarpal III. (55) Metacarpal III slightly bowed.

Pelvis.--(56) Width of pelvis through antitrochanters 60-63 per cent of length of innominate from anterior edge of llium to 1schial angle (Table 3). (57) Pectineal process obsolete, only moderately produced beyond acetabular border, and with 1 ts apex polnted. (58) Depression on medial side of pectineal process shallowly excavated, and without foramen. (59) Posterior $111 a c$ crest without prominenoe. (60) Bldge origlnating on posterlor $111 \mathrm{ac}$ crest at level of 1110-1schlac fenestra, and contlnulag ventrad and posteriad towards posterlor border of 111um w1th prominence weakly arlsing from 1ts posterior portion. (61) Dorsal face of post_acetabular 111 um much broadened anterlad, narrowing abruptly posterlad to form acute apex of very short, broad dorsal roof of posterior process. (62) Caudal face of post. acetabular 1l1um enlarged, broadly triangular, and vertical In position, with 1 ts posterodorsal a pex forming posteromedial wall of posterior process. (63) Lateral face of post. acetabular 1l1um w1th 1 ts posterodorsal äpex acute, and forming shortened lateral wøll of posterior process. (64) Benal bar obsolete, w1 th both bar and poster1or process excavated by renal depression. (65) Ischlum at angle of about 160 degrees to ventral edge of posterior 111 ac crest. (66) W1dth through transverge process of fourth synsacral vertebra $67-85$ per cent length of synsacrum from centrum of 
first synsacral vertebre through transverse process of fourth synsacral vertebra.

Pemur.-- (67) D1stal width about 17 per cent length (Table 5). (68) Head moderately enlarged, nelther bent dorsally nor rotated posterlorly. (69) Neck only moderately long. (70) Illac facet without compression, w1th posterior border convex. (71) Dorsal crest of trochanter compressed and reflected, w1 th 1 ts dorsal border rounded. (72) Trochanteric ridge 23-25 per cent length of femur. (73) D18tal depth 76-83 per cent of d1stal w1dth. (74) Internal condyle moderately wide, and with 1ts anterlor border much produced throughout. (75) Exteraal condyle compressed, and rounded anterlorly.

Tiblotarsus.--(76) Depth of 1nner cnem1al crest 65-74 per cent of 1 ts length (Table 4). (77) Outer cnemial crest stralght. (78) Interarticular tubercle strongly produced. (79) Area between external articular surface and outer cnemlal crest moderately concave in dorsal view. (80) Post terior margin between external and Internal articular surface with a distinct notch. (81) Area just anterior to rlage from proximel internal I1gamertal attachment without deeply excavated depression. (82) Internal I1gamental prominence on 1nternal condyle moderately produced. (83) Face of Internal condyle moderately excavated, w1th 1 ts border moderately elevated. (84) Dorsal border of supratendinal bridge usually stralght. 
Tarsometatarsus.--(85) D1stal w1dth 17-18 per cent of length (Table 6). (86) Proximal depth $91-98$ per cent of proximal w1dth. (87) Intercotylar prominence moderately deflected, and with 1ts apex usually polnted. (88) Posterior 1ntercotylar area usually veessarated, but may be weakly excarated as a triangular depression. (89) Area surrounding posterior opening of Inner proximal foramen shallowly excavated. (90) Hypotarsus with two well devel_ oped and one obsolete calcaneal ridges, two calcaneal grooves, and usually one, sometimes two, closed calcaneal canals. (91) Anterlor metatarsal groove reduced or absent. (92) Depth of midale trochlea 50-53 per cent of distal w1dth. (93) Trochlea for diglt II moderately inflected. (94) W1ng of trochlea for digit IV depressed dorsoventrally, thus entire trochlea wuch deeper than long. Intermembral proportions...- (95) W1ag/leg 67-67 per cent (Table 2). (96) Ulna/humerus 92-94 per cent. (97) Tarsometatarsus/femur 75-82 per cent. (98) Tarsometatarsus/t1blotarsus 58 per cent. (99) Humerue/fexur 83-89 per cont. (100) Humerus/t1blotarsus 58.51 per cent. (101) U1na/fenur 78-82 per cent. (102) Ulna/t1b1otarsus 55-58 per cent. (103) Ulna/tarsometatarsus 95-110 per cent. (104) Carpometacarpus/femur 47-50 per cent. (105) Carpometacarpus/ t1blotarsus 33-35 per cent. (106) Carpowetacarpus/tarsometatarsus 57-66 per cent. (107) Tarsometatarsus/humerus 85-99 per cent. (108) Il1um/sternum 65-69 per cent. 
(109) Helght of sternal car1na/111um 45-46 per cent.

\section{Callipepla Wagler 1832}

The single specles, Callipepla squamata (V1gors 1830)

occurs in the southwestern Un1ted States and northern Hexico. Measurements are given in Table 7.

Bostrum.-. (1) Belat1vely long and shallow. (2) Nasal fossae ell1ptical.

Sternum--- (3) He1ght of carlna through sternal plate 30-31 per cent length of sternum (Table 3). (4) Dorsal 11p of coracoldal sulcus projected well beyond ventral 11p. (5) Depressions on anterior portion of sternal plate obsolete to deep and slightly to moderately pneumat1c. (6) Base of posterlor lateral process less than one-half width of sternal plate at 1 ts midale.

Coraco1d.--(7) Ent1re proximel end stra1ght above procoracold process. (8) Head narrowly rounded, moderately compressed, and moderately inrlected. (9) Brachial tuberosity w1th slight dorsal and ventral overhang. (10) Furcular facet moderately inflated. (11) Blclpltal attachment well. developed, with margin between 1t and head concave. (12) Shaft w1de proximally, w1th distal portion of 1ts ventral surface usually concave mediliy. (13) Procoracold process w1th 1ts apex acute. (14) Dorsal Intermuscular I1ne swinglng out to medial surface of shaft, w1th distal half sharply ralsed. (15) Ventral intermuscular I1ne terminating at tip of sterno- 
coracoldal process. (16) Dorsal face weakly excavated d1stally, and without fosse. (17) Tubercle for ligamentum sterno-corscoldeum dorsale obsolete, but rounded. (18) Internal distal angle with distinct 1rregular tubercle extending obliquely to above lateral end of sterral facet. (19) Sterno-corecoldal process w1th distal margln elightly oblique, not proâced as a sharply raised rlage, and without dorsal groove; w1th 1ts tip alrected lateraily, and ending In \& terminal knob. (20) DIstal border of sternal facet usually deeply concave.

Scepula...-(21) Glenold facet ovel in dorsal view. (22) Dorsal depression Just mediad to glenold facet unexcaveted, shillowly excavated or moderately excevated. (23) Erldge between acromion process and glenold facet about one-half width of glenold facet. (24) Acromlon process with 1 ts apex rounded, and slightly derlected.

Humerus.-- (25) Pneumetic fossa a moderetely long oval or ovalo1d, w1thout 1nner shelf. (26) Median crest usually weakly developed, elevated only at, 1ts, middle. (27) Cepital Eroove moderately excavated, with 1ts internal marein moderately elevated. (28) Margin between head and Internal. tuberosity woderately concave. (29) Head brokder than long in anconal view. (30) Rlage along medial border of fossa II - moderately swollen, elongate, and with 1 ts apex acute. (31) Fossa II well developed. (32) Lat1seimus ridge orig1neting on leteral eoge of shaft, but swiuging in onto anconal 
face proximally. (33) External tuberosity moderately inflated. (34) B1c1p1tal crest ar1a1ng gently from shaft, narrowly rounded, and with its distal border lacklng a groove.

(35) Deltold crest moderately developed, slightly 1uflected, and with its summit knob-11ke. (36) Eateplcondyle at level of Internal condyle. (37) Enteplcondyler prominence moderately produced, with 1ts pit placed on palmar face.

(38) Depression of M. brachlalls antlcus usually shallowly excavated. (39) D1stal border of external condyle rounded in anconal view.

Ulna.--(40) Olecranon process atrongly produced, and with 1 ts apex polnted. (41) External cotyla moderately elongate, roundsd throughout, with 1ts distal border sloplng gently 1nto shaft, and only slightly notched by proximal radial impression. (42) Impression for M. brachialis ant1. cus excavated, with 1 ts borders distinct. (43) Helght at middle of shaft $63-66$ per eent of helght just distal to external cotyla (Table 4). (44) Distal radial Impression obsolete. (45) Notch between carpal tubercsity and interual condyle well developed. (46) External condyle well produced, arlsing abruptly from shaft, and rounded throughout.

Carpometacarpus.--(47) Metacarpal I noderately polnted temlnally. (48) Blage separating anterlor carpal fosse from exosvated area above p1siforn process produced, and extends well onto base of metacarpal I. (49) P1siform process round or ovalold in Internal view, slightly refleoted dorsad, thus 
usually below, cccasionally at level of dorsal rim of inver carpal trochlea. (50) Ligamental attachment of pialform process produced and auch swollen proxlmally, flattened distally, with proximal portion connected to plsiform process by bouy bridge. (51) Internal carpal trochlea with 1 ts proximal border deeply notched, and 1 ts ventral border W1 thout notch. (52) Intermetecarpal tubercle extending to, but not ankylosing w1th metecarpal III, and distally placed with a small spoce between 1 ts posterior border and junction of metacarpals II and III. (53) Tubercle on Interaal proximal face of metacarpal III obsolete. (54) Vith one strongly developed tubercle on external proximal face of metacarpal III, (55) Metacarpal III sl1ghtly bowed. Eelv1s.--(56) Width of pelvis through antitrochanters 58.62 per cent of length of 1unominate from anterlor edge of llium to ischial angle (Table 3). (57) Pectineal process obsolete, only moderately produced beyond acetabular border, and with 1 ts apex polnted. (58) Depression on medial side of pectineal process shallowly excavated, and Without foramen. (59) Fosterior 111 ac crest w1 thout prom1neace. (60) Ridge orlglnating on posterlor 111 ac crest at level of 1110-1schlac fenestra, and contlnulng ventrad and posterlad towards posterior border of 111 um w1th prominence weakly arlslug from its posterlor portion. (61) Dorsal face of post-acetabular 111 um roderstely broad anterlad, narrowing abruptly poster1ad to form scute apex of short, broad, dorsal 
roof of posterior process. (62) Caudel face of post-acetabular 1lium enlarged, trlangular, and vertical in position, with its posterodorsal apex forming posteromedial wall of posterior process. (63) Lateral face of post_acetabular lilum with 1 ts pesterodorsal apex acute, and forming shortened lateral wall of posterlor process. (64) Eenal bar very alender, with both bar and posterior process excavated by renal depression. (65) Ischium at angle of about 160 degrees to ventral edge of posterlor 111ac crest. (66) W1ath through transverse process of fourth synsacral vertebra 71-80 per cent of length of synsecrum from centrum of first synsacral vertebra through transverse process of fourth synsacral vertebra.

Femur.--(67) Distal w1ath $17-18$ per cent of length (Table 5). (68) Heed moderately enlarged, nelther bent dorsally nor rotated posteriorly. (69) Neck only moderately long. (70) Illac facet without compression, w1th posterlor border convex. (71) Dorsal crest of trochanter compressed and reflected, with 1 ts dorsal border rounded. (72) Trochanter ridge 24 per cent length of femur. (73) D18tal depth $76-82$ per cent of distal wath. (74) Internal condyle moderately wide, and with 1 ts anterlor border much produced throughout. (75) External condyle compressed and rounded anteriorly.

T1blotarsus.--(76) Depth of 1nner coemlal crest 64-73 per cent of 1ts length (Table 4). (77) Outer cnemlal crest 
usually stralght. (78) Interarticular tubercle moderately produced. (79) Area between external articular surface and outer cnemlal crest moderately concave in dorsal view. (80) Posterior margin between external and internal articular surfaces with a distinct notch. (81) Area just anterior to ridge from proximal internal 11gamental attachment without deeply excavated depression. (82) Internal 11gamental prominence on Internal condyle moderately produced. (83) Face of Internal condyle moderately excavated, with 1 ts border moderately elevated. (84) Dorsal border of supratendinal bridge stralght.

Tarsometatarsus.--(85) D1stal w1dth $15-18$ per cent of length (Table 6). (86) Proximal depth 95-98 per cent of proximal width. (87) Intercotylar prominence moderately deflected, and with 1 ts apex usually polnted. (88) Posterior Intercotylar area weakly excavater as a triangular depression. (89) Area surrounding posterior opening of lnner proximal foramen shallowly excavated. (90) Hypotarsus with two well developed and one obsolete calcaneal rldges, two calcaneal grooves, and two closed calcaneal canals. (91) Anterior face of shaft moderately excavated by anterior metatarsal groove. (92) Depth of middle trochlea 52-59 per cent of distal width. (93) Trochlea for diglt II only slightly 1nflected. (94) Wing of trochlea for dig1t IV depressed dorsoventrally, thus entire trochlea much deeper than long. Interwembral proportions.-- (95) Wing/leg 67-69 per 
cent (Table 2). (96) UIna/humerus 92 per cent. (97) Tarsometatarsus/femur 79-82 per cent. (98) Tarsometatarsus/t1blotarsus 59 per cent. (99) Humerus/femur 85-89 per cent. (100) Humerus/t1blotarsus 63-65 per cent. (101) Ulna/femur 78.82 per cent. (102) Ulna/t1blotarsus 58-59 per cent. (103) Ulna/tarsometatarsus 95-102 per cent. (104) Carpometacarpus/femur 47-48 per cent. (105) Carpometacarpus-t1biotarsus 34-35 per cent. (106) Carpometacarpus/tarsometatarsus 58-61 per cent. (107) Tarsometatarsus/humerus 89-96 per cent. (108) I11um/sternum $66-69$ per cent. (109) Helght of sternal car1na/111um 43-47 per cent.

\section{Col1nus Goldruss 1820}

The genus Collnus occurs in the United States east of the Bockles, on Cuba and the Isle of P1nes, and through Mexico and Central America to Colombla and Venezuela. There are four living specles. Table ? Includes measurements of c. V1rgin1anus (L1nnaeus 1758), C. n1grogular18 (Gould 1843), and C. leucopogon (Lesson 1842). Bostrum.--(1) Belatively long and shallow. (2) Nasal fossae elliptical.

Sternum.-- (3) Helght of carlne through sternal plate 25-32 per cent length of sternum (Table 3). (4) Dorsal 11p of coracoldal sulcus projected well beyond ventral 11p. (5) Depressions on anterior portion of sternal plate usually shallow and non-pneumatic. (6) Base of posterlor lateral 
process less than one-half width of sternal plate at 1ts made.

Coracold.--(7) Entire proximal end stralght above procoracoid process. (8) Head narrowly rounded, moderately compressed, moderately reflected or inflected. (9) Brachial tuberosity with slight dorsal and ventral overhang. (10) Furcular facet weakly or moderately 1nflated. (11) Blolp1tal attachment well developed, w1th margin between it and head concare. (12) Shaft w1de preximar1y, w1th distal portion of 1ts ventral surface concave medially. (13) Procoracolo process w1th 1ts apex acute or rounded. (14) Dorsal Intermuscular line swlnglng out to medial surface of shaft, with distal half sharply ralsed. (15) Ventral intermuscular line term1nating at tip of sterno-coracoldal process. (16) Dorsal face moderately excavated distally, and without distinct fossa. (17) Tubercle for 11gamentum sterno-coracoldeum dorsale obsolete or well developed, Irregular in shape or rounded. (18) Internal distal angle without distinct tubercle or ridge on dorsal face. (19) Sterno-coracoldal process with distal margin slightly oblique, not produced as a sharply ralsed ridge, and without dorsal groove; with 1ts tip directed laterally, and ending in a terminal knob. (20) Distal border of sterial facet usually deeply concave.

Soapula.--(21) Glenold facet oval in dorsal view. (22) Jorsal depression just mediad to glenold facet moderately to deeply excavated. (23) Bridge between acrowlon pro- 
cess and glenold facet less than one-third to about half w1dth of glenold facet. (24) Acromion process w1th 1ts apex rounded, and usually moderately deflected.

Humerus.--(25) Pneumat1c fossa short to very long, ell1ptical, oval, or ovelo1d, w1thout lnner shelf. (26) Med1an crest moderately to strongly developed, elevated only at 1ts m1ddle. (27) Capital groove usually moderately excavated, w1th 1 ts 1 internal margin usually moderately elevated. (28) Margin between head and internal tuberosity moderately concave. (29) Head broader than long in anconal view. (30) Bldge along medial border of fossa II slightly to moderately swollen, elongate, and with 1 ts apex acute. (31) Fossa II well developed. (32) Lat1ss1mus ridge orig1nating on lateral edge of shaft, but swlnging in onto anconal face proximally. (33) External tuberos1ty moderately 1nflated. (34) Blolpltal crest ar1a1ng gently from shaft, usually narrowly rounded, and with 1 ts dorsal border lacklng a groove. (35) Deltold crest moderately developed slightly inflected, and with 1 ts summit flattened or knob-like. (36) Enteplcondyle usually at level of 1nternal condyle. (37) Enteplcondylar prominence moderately produced, w1th 1 ts plt placed on 1nternal face. (38) Depression of M. brachlalis ant1ous usually moderately exoavated. (39) D1 stal border of extermal condyle rounded in anconal view.

Ulna. - (40) Olecranon process strongly produced, and with 1ts apex polnted. (41) External cotyla moderately 
elongate, rounded throughout, with 1 ts distal border sloping gently into shaft, and only alightly notched by proximal radial 1mpression. (42) Impression for M. brachlalis ant1cus excavated, with 1 te borders distinct. (43) Helght at midale of shaft 62-7? per cent of helght just distal to external cotyla. (44) D1stal radial 1mpression obsolete. (45) Notch between carpal tuberosity and internal condyle well developed. (46) External condyle well produced, ar1s1ng abruptly from shaft, and rounded throughout.

Carponetacarous.---(47) Metacarpal I moderately polnted or rounded terminally. (48) Bldge separating anterlor carpal fossa from excavated area above plsiforw process produced, and extends well onto base of metacarpal I. (49) P181_ form process round, ovalo1d, oval or ell1ptical in internal vlew, slightly reflected dorsad, thus usually below, occasionally at level of dorsal rim of inner carpal trochlea. (50) L1gamental attachment of p1s1form process produced and much swollen proximally, flattened distally, w1th proximal portioc usually connected to plalform process by bony bridge. (51) Internal carpal trochlea w1th 1ts proximal border shellowly concave or slightly notched, and 1 ts ventral border w1 thout notch. (52) Intermetacarpal tubercle extending to or allghtly beyond, but usually not ankylosing w1th metacarpal III, and distally placed with a small space between 1ts posterior border and junction of metacarpals II and III. (53) Tubercle on internal proximal face of metacarpal III 
obsolete. (54) W1th one strongly developed tubercle on external proximal face of metacarpal III. (55) Metacarpal III slightly bowed.

Pelvis.--(56) width of pelv1s through ant1trochanters 44-51 per cent of length of Innominate from anterior edge of 111um to 1schial angle (Table 3). (57) Pectineal process obsolete, only moderately produced beyond acetabular border, and with 1 ts apex usually polnted. (58) Depression on medial side of pectineal process shallowly excavated, sud w1 thout foramen. (59) Posterior 111ac crest w1 thout prominence. (60) Ridge originating on posterior 1llac crest at level of 1110-1schiac fenestra, and continuing ventrad and posterlad towards posterior border of 111 um w1th prominence sharply arising from 1ts posterior portion. (61) Dorsal face of post_acetabular 111um moderately broad anteriad, narrowing abruptly posteriad to form acute apex of short, . broad, dorsal roof of posterior process. (62) Caudal face of post-acetabular 111um enlarged, triangular, and vert1cal in position, with 1 ts posterodorsal apex forming posteromedial wall of posterior process. (63) Lateral face of post-acetabular 111um w1th 1ts posterodorsal apex acute, and forming shortened lateral wall of posterior process. (64) Renal bar very slender, w1th both bar and poster1or process excavated by renal depression. (65) Ischium at angle of about 160 degrees to ventral edge of posterior $111 a c$ crest. (66) Width through transverse processes of 
fourth synsacral vertebra 57-68 per cent of length of synsacrum from centrum of flrst synsacral vertebra through transverse process of fourth synsacral vertebra. Femur.--(67) D1stal w1dth 15-18 per cent of. length (Table 5). (68) Head moderately enlarged, nelther bent dorsally nor rotated posterlorly. (69) Neck only moderately long. (70) I11a facet without compression, w1 th posterior border convex. (71) Dorsal crest of trochanter depressed and deflected or compressed and reflected, w1th 1 ts dorsal border flat or rounded. (72) Trochanteric r1dge 21-25 per cent length of femur. (73) Distal depth 78-90 per cent of distal w1dth. (74) Internel condyle moderately wide, and w1th 1 ts anterior border much produced throughout. (75) External condyle compressed, and rounded anteriorly. T1blotarsus.-- (76) Depth of 1nner cnemlal crest 54-69 per cent of 1 ts length (Table 4). (77) Outer cnemial crest usually stralght. (78) Interarticular tubercle usually moderately produced. (79) Area between external art1cular surface and outer cnemial crest moderately concave in dorsal view. (80) Posterior margin between external and 1nternal articular surface w1th a distinct notch. (81) Area just anterior to ridge from proximal internal 11gamental attachment w1 thout deeply excavated depression. (82) Internal ligamental prominence on internal condyle moderately produced. (83) Face of Internal condyle moderately excavated, w1th 1ts border moderately elevated. (84) Dorsal border of 
supratendinal bridge oblique or stralght.

Tarsometatarsus.--(85) D1stal w1ath $16-19$ per cent of length (Table 6). (86) Proximal depth 93-100 per cent of proximal w1dth. (87) Intercotylar prominence moderately deflected, and with 1 ts apex usually polnted. (88) Posterior intercotylar area weakly excavated as a triangular depression. (89) Area surrotind.ng posterlor opening of lnaer proximal foramen shallowly excavated. (90) Hypotarsus with two well developed and one obsolete calcaneal ridges, two calcaneal grooves, and two closed calcaneal canals. (91) Anterlor face of shaft usually moderately excavated by anterior metatarsal groove. (92) Depth of m1dale trochlea $52-60$ per cent of distal width. (93) Trochlea for diglt II only slightly 1nflected. (94) Wing of trochlea for digit IV depressed dorsoventrally, thus ent1re trochlea much deeper than long.

Intermembral proportions.-- (95) W1ng/leg $63-69$ per cent (Table 2). (96) Ulna/humerus 86-91 per cent. (97) Tarsometatarsus/femur 73-83 per cent. (98) Tarsometatarsus/t1b10tarsus 57-61 per cent. (99) Humerus/femur $82-88$ per cent. (200) Humerus/t1blotarsus 62-66 per cent. (101) U1na/femur 72-79 per cent. (102) UIna/t1biotarsus 53-59 per cent. (103) U1na/tarsometatarsus 92-104 per cent. (104) Carpometacarpus/femur $43-47$ per cent. (105) Carpometacarpus/ t1blotarsus 33-35 per cent. (106) Carpometacarpus/tarso. metatarsus 55-62 per cent. (107) Tarsometatarsus/humerus 
86-98 per cent. (108) Illum/sternum 66-75 per cent. (109) Helght of sternal carina/111um $37-45$ per cent.

\section{Srecific Variation in Colinus}

Coracold...-(1) Head usuelly moderately reflected (moderately inflected in C. nlgrogular18). (2) Furcular facet moderately inflated (weakly inflated in C. nigrogularis). (3) Procoracold process with 1 ts apex usually rounded (acute In C. n1Erogular1s). (4) Tubercle for 11gamentum sterno.. coracoldeum dorsale usually obsolete and 1 rregular in shape (well developed and round in C. leucopogon).

Scapula.-- (5) Bridge between acromion process and glenold facet usually about one-half width of glenold facet (less then one-third width in C. n1grogularis).

Humerus.-. (6) Pneumatic fossa usually moderately long (very long in C. Digrogularis). (7) Median crest moderetely developed (usually strongly developed in C. V1rginianus). (8) Rldge along medial border of fossa II moderately swollen (sl1ghtly swollen in C. nlgrogularis). (9) Deltold crest with 1ts apex flattened (usually knob-11ke in C. virgla1anus).

Carpometacarpus.-.-(10) Metacarpal I usually moderately poluted terminally (rounded terminally in C. leucopogon). Femur.-- (11) Dorsal crest of trochanter usually depressed and deflected w1th 1 ts dorsal border usually flat (usually compressed and reflected, dorsal border usually round in C. leucopogon). 
T1blotarsus.--(12) Dorsal border of supratendinal bridge usually oblique (straight in C. leucopogon).

Intermembral oroportions.--Spec1es of Col1nus Inseparable on 1ntermembral proportions.

Bemarks.-.The skeletons of the Becent species of Collnus are very slwilar. Collnus v1rginianus resembles $\mathrm{C}$. leucopogon in 11 iz of 12 characters, C. nlerogular1s in four of 12 characters, and 18 unlque in two characters (these are subject to some 1ndividual variation). Col1nus n1grogularis resembles C. V1rglatanus in four of 12 characters, $C$. leucopogon in two of 12 characters, and is unlque in $81 x$ characters. C. leucopogon resembles C. V1rginlanus in $81 x$ of 12 characters, $C$. algrogular1s in two of 12 characters and is unlque in four characters.

Col1nus v1rg1nlanus averages largest, C. leucopogon second largest, and C. nlgrogular1s the smallest (Table 7).

Subspec1fic Variation in Col1nus V1rginianus United States populations of Recent Colinus V1rginlanus show a gradual decrease in mean skeletal size from north to south (Table 8).

No qualitative skeletal differences separate the subspecies of Col1nus V1rginianus, but one qualitative character appears to follow a similar north-south gradient. The Mexican samples are too small to indicate trends.

A north-south decrease in mean size occurs in United 
States bob-whites. The Michlgan population of $\mathrm{C}$. V1rginlanus is largest, and the Illinols population second largest in each of 20 measurements. North Florida quall, representing 1ntergrades between $C_{\text {. }} \nabla \cdot$ v1rginlanus and C. V. floridanus, are third largest in 19 of 20 measurements, whereas the peninsular subspecles C. V. Ploridanus is the smallest in 19 of 20 measurements.

It 18 difficult to make a positive statement about the size of the Mexican races of C. V1rginianus because of the small sample of these forms. However, both C. V. $1 \mathrm{~ns} 1 \mathrm{gn} 1 \mathrm{~s}$ from Chlapas, and C. V. coyolcos from Oaxaca are smaller than C. V. V1rginlanus from Michlgan and Illinols.1n all 20 measurewents.

The development of the median crest of the humerus appears to show a north-south gradient in the subspecies of C. virginlanus and thus is the only qualitative character that may be assoolated with any definite trend. In c. v. virglnianus from Michigan 85 per cent of 20 specimens have the median crest strongly developed, whlle 15 per cent are moderately or weakly developed. In C. V. virglnianus from southern Illinols 71 per cent of 38 specimens have the median crest strongly developed, whlle 29 per cent are moderately or weakly developed. In intergrades between C. v. v1rglnianus and c. v. Ploridanus frow North Florida 38 per cent of 13 specimens have the median crest strongly developed, whlle 62 per cent are moderately or weakly de- 
veloped. In C. v. Ploridanus from peninsular Florida 29 per cent of seven specimens have the median crest strongly developed, whlle 71 per cent are moderately or weakly developed. In C. v. 1nsign1s from Chiapas, Mexico, 40 per cent of Iive specimens have the median crest strongly developed, whlle 60 per cent are moderately developed. One specimen of C. 7 . coyolcos from Oaxaca, Mexico, has the median crest strongly developed.

\section{Lophortyx Bonaparte 1838}

The genus Lophortyx occurs in the western Unlted States and western Mexico. Table $?$ includes measurements of the three recognized specles, L. callfornica (Shaw 1798), L. gambel11 Gambel 1843, and L. douglas11 (V1gors 1829).
Bostrum.
(1) Relatively long and shallow.
(2) Nasal fossae ell1ptical.

Sternum.-- (3) Helght of carlna through sternal plate 28-31 per cent leagth of sternum (Table 3). (4) Dorsal 11p of coraccเม่ สulcus projected well beyond ventral $11 \mathrm{p}$. (5) Depressions on anterior sternal plate obsolete or deep, slightly to moderately pneumatio. (6) Base of posterior lateral process less than one-half widh of sternal plate at Its midale.

Coracold.--(7) Ent1re proximal end stralght above procoracold process. (8) Head narrowly rounded, moderately collpressed, and moderately inflected.

(9) Brachlal tuberosity 
with slight dorsal and ventral overhang. (10) Furcular facet weakly 1nflated. (11) Blclpltal attachment well developed, w1th margin between 1t and head concave. (12) Shaft narrow or w1de proximally, with distal portion of 1ts ventral surface convex or concave medially. (13) Procoracold process w1th 1 ts apex rounded. (14) Dorsal Intermuscular line swluglug out to medial surface of shaft, with distal half sharply ralsed. (15) Ventral intermuscular ilne terminating at tip of sterno-coracoldal process. (16) Dorsal face weakly or moderately excavated distally, and without fossa. (17) Tubercle for 11gamentum sterno-coracoldeum dorsale obsolete or well developed, and round. (18) Interal distal angle w1thout distinot tubercle or ridge on dorsal face. (19) Stemo-coracoldal process with distal margin alightly oblique, not produced as a sharply ralsed ridge, and w1thout dorsal groove; w1th 1 ts t1p directed laterally, and ending in a terminal knob. (20) Dlstal border of sternal facet deeply to very deeply concave.

Scapula.--(zi) Glenold facet oval in dorsal view. (22) Dorsal depression just mediad to glenold facet shallowly to moderately excavated. (23) Bridge between acromion process and glenold facet about one-half to more than one-half wlath of glenold facet. (24) Acromion process with 1ts apex rounded and usually slightly derlected.

Humerus.-- (25) Pneumatic fossa a short to moderately long oval or ell1pse, without Inner shelf. (26) Median crest 
weak to strongly developed, elevated throughout or only at 1ts middle. (27) Capital groove moderately excavated, with Its 1nternal margin moderately elevated. (28) Margln between head and Internal tuberosity moderately concave. (29) Head as broad as long or broader than long in anconal view. (30) Ridge along medial border of fossa II moderately swollen, elongate, and w1th 1ts apex acute. (31) Fossa II well developed. (32) Latissimus ridge originating on lateral edge of shaft, but swinging in onto anconal face proximaliy. (33) External tuberosity moderately inflated. (34) Blolpital crest ar1sing gently from shaft, narrow $2 y$ rounded, and with 1ts distal border lacklng a groove. (35) Delto1d crest moderately developed, slightly Inflected, and with 1 ts summ1t usually flattened. (36) Enteplcondyle produced slightly beyond 1nternal condyle. (37) Enteplcondylar prom1nenoe moderately produced, with 1ts p1t placed on internal face. (38) Depression of M. brachlalis anticus moderately excavated. (39) Distal border of external condyle rounded in anconal view.

UIna.--(40) 0lecranon process strongly produced, with 1ts apex polnted. (41) Bxternal cotyla moderately elongate, rounded throughout, with 1ts distal border sloping gently Into sheft, and usually only slightly notched by proxlmal radial 1mpression. (42) Impression for M. brachlal1s ant1ous excavated, with 1 ts borders distinct. (43) Helght at midde of shaft 61-72 per cent of helght just distal to external 
cotyle (Table 4). (44) Distal radial impression obsolete. (45) Notch between carpal tuberosity and Internal condyle well developed. (46) External condyle well produced, arising gently from shaft, and rounded throughout.

Carpometacarpus.--(47) Metacarpal I moderately polnted or rounded terminally. (48) Eldge separating anterlor carpal fossa from excarated area above plsiform process produced, and extends well onto base of metacarpal I. (49) 'Plsiforw process ovalo1d in internal view, slightly or moderately reflected dorsad, thus below, at, or slightly above level of dorsal rim of Inner carpal trochlea. (50) Ilgamental attachment of pisiform process produced and. much swollen proximally, flattened distally, with proximal portion usually connected to plsiform process by bony bridge. (51) Internal carpal trochlea with 1 ts proximal border usually slightly notched, and 1ts ventral border w1thout notch. (52) Interwetacarpal tubercle extending to and sometimes ankylosing with metacarpal III, and distally placed W1th a gmall space between 1 ts posterior border and junction of metacarpals II and III. (53) Tubercle on 1nternal proximal face of metacarpal III obsolete. (54) W1th one strongly developed tubercle on external proximal face of metacarpal III. (55) Metroarpal III slightly bowed. Pelv1s.--(56) W1dth of pelvis through ant1trochanters $54-57$ per cent of length of 1nnominate from anterior edge of 111 um to 1 schlal angle (Table 3). (57) Pectineal process 
obsolete, only moderately produced beyond acetabular border, and w1th 1 ts apex polnted. (58) Depression on medial side of pectineal process shallowly excavated, and w1 thout foramen. (59) Posterior 111 ac crest without prominence. (60) B1dge orlolnating on posterior 111 ac crest at level of 1110-1schiac fenestra, and continulng ventrad and posterlad towards posterlor border of 111 um w1th prominence sharply ar1sing from 1ts posterior portion. (61) Dorsal face of post_acetabular 111 um moderately broad anterlad, narrowing abruptly posteriad to form acute apex of short, broad, dorgal roof of posterlor process. (62) Caudal face of post_acetabular enlarged, triangular, and vertical in position, with 1 ts posterodorsal apex forming posteromedial wall of posterlor process. (63) Lateral face of post-acetabular 111um w1th 1ts posterodorsal apex acute, and formlng shortened lateral wall of posterlor process. (64) Benal bar very slender, with both bar and posterior process excavated by renal depression. (65) Ischlum at angle of about 160 degrees to ventral edge of posterlor 111 ac crest. (66) width through transverse process of fourth synsacral vertebra $67-76$ per cent of length of synsacrum from centrum of flrst synsacral vertebra through transverse process of fourth synsacral vertebra. Femur.--(67) D1stal width $17-18$ per cent of length (Table 5). (68) Head moderately or much enlarged, nelther bent dorsally nor rotated posterlorly. (69) Neck only moderately long. (70) Illac facet w1thout compression, w1th 
posterior border convex. (71) Dorsal crest of trochanter usually compressed and reflected, with 1 ts dorsal border rounded. (72) Trochanter1c ridge 24-25 per cent length of femur. (73) D1stal depth 77-85 per cent of distal w1dth. (74) Internal condyle moderately wide, and with 1 ts anterior border much produced throughout. (75) External condyle compressed, and rounded anteriorly.

T1blotarsus.--(76) Depth of 1nner cnemial crest 58-67 per cent of 1 ts length. (77) Outer cnemial crest stralght or decurved. (78) Interarticular tubercle moderately produced. (79) Area between external articular surface and outer cnemial crest moderately concave in dorsal vlew. (80) Posterior margin between external and 1nternal articular surfaces w1 th a distinct notch. (81) Area just anterior to ridge from proximal internal ligamental attachment w1thout deeply excavated depression. (82) Internal I1gamental prominence on Internal condyle moderately produced. (83) Face of Internal condyle moderately excavated, with its border woderately elevated. (84) Dorsal border of supratendinal bridge usually straight.

Tarsometatarsus.--(85) D1stal w1dth 18-20 per eent of length (Table 6). (86) Proximal depth 93-100 per cent of proximal w1dth. (87) Intercotylar prominence moderately deflected, and with 1 ts apex pointed. (38) Posterior intercotylar area usually weakly excavated as a triangular depression. (89) Area surrounding posterlor opening of Inner 
proximal foramen shallowly excavated. (90) Hypotarsus with two well developed and one obsolete calcaneal ridges, two calcaneal grooves, and two closed calcaneal canals. (91) Anterior wetatarsal groove usually reduced. (92) Depth of midale trochlea about 51-57 per cent of distal w1dth. (93) Trochlea for diglt II only slightly inflected. (94) W1ng of trochlea for digit IV depressed dorsoventrally, thus entire trochlea much deeper than long. Intermembral proportions.--(95) Wing/leg $60-66$ per cent (Table 7). (96) 01na/humerus $86-89$ per cent. (97) Tarsometatarsus/femur 76_82 per cent. (98) Tarsometatarsus/t1b1otarsus 57-59 per cent. (99) Humerus/femur 79-85 per cent. (100) Humerus/tiblotarsus 58.65 per cent. (101) Ulna/femur 68-74 per cent. (102) U1na/tibiotarsus 50-56 per cent. (103) 01na/tarsonetatarsus 87-97 per cent. (104) Carpometacarpus/femur $37-45$ per cent. (105) Carpometacarpus/ t1blotarsus 31-35 per cent. (106) carpometacarpus/tarsometatarsus 54-60 per cent. (107) Tarsometatarsus/humerus 89-99 per cent. (108) Il1um/stiernum 66-70 per cent. (109) Helght of sternal cardna/111um $42-45$ per cert.

\section{Specific Variation in Lophortyx}

In this section when two of the three species agree in a particular character, the usual condition is mentioned first, followed by the exception shown in the third species. Sternum.--(1) Depressions on anterior portion of sternal 
plate deep (obsolete in L. callforn1ca); slightly to moderately pneumat1c in L. douglas12, sightly pneuxatic in $\mathrm{L}$. cal1forn1ca, moderately pneumatic in L. gambel11.

Coracold.--(2) Shaft w1de proximally (narrow proximally in I. cal1forn1ca), with distal portion of 1ts ventral surface concave medially (convex medially in L. gambel11).

(3) Dorsal face weakly excavated distally (moderately exca_ vated distally in L. douglas11). (4) Tubercle for 11gamentum sterno-coracoldeum dorsale well developed (obsolete In L. callforalca). (5) D1stal border of sternal facet deeply concave (very deeply concave in L. gambel11).

Scapula.--(6) Dorsal depression just med1ad to glenold facet shallowly to mocerately excavated in L. douglas11. shallowly excavated in L. californica, moderately excavated 1n L. gambel11. (7) Bridge between acromion process and glenold facet about one-half width of glencld facet (more than one-half width of glenold facet in L. gambel11).

Humerus.--(8) Comblned proximal width, middle shaft width, ar:A distal width 58-59 per cent of length $(60.63$ per cent of length in L. Cal1fornica). (9) Proximal width 27 per cent of length (28-30 per cent of length in L. callfornica). (10) Median crest strongly developed, elevated only at 1 ts middle (weak and elevated throughout in L. douglasi1). (11) Head broader than long in anconal view (as broad as long 10 I. gambel11).

Ulna.--(12) Helght at miale of shaft $67-72$ per cent of 
helght just distal to external cotyla (61 per cent of helght 1n L. gambel11).

Carpometacarous..-(13) Proximal width through p1s1form process 65-67 per cent of proximal helght through metacarpal I (61-62 per cent of proximal helght in L. cal1fornica). (14) Metacarpal I rounded terminally (moderately polnted terminally in L. callfornica). (15) P1slform process slightly reflected dorsad, thus below level of dorsal rim of inner carpal trochlea (moderately reflected dorsad, thus at or slightly above dorsal rim of 1nner carpal trochlea in L. gambel11). (16) Intermetacarpal tubercle usually extending to and ankylosing w1th metacarpal III (extending to, but not ankylosing w1th metacarpal III in L. douglas11).

Femur.--(17) Head noderately large (much enlarged in L. gambel11).

Tlb1otarsus.-. (18) Proximal depth 76-77 per cent of proximal width (72-73 per cent of proximal width 1n L. callfornica). (19) Outer cnemial crest stralght or slightly decurved in L. cal1forn1ca, stra1ght in I. douglas1i, decurved in L. Gambel11.

Intermembral proportions.-.-(20) Wing/leg 60_63 per cent (66 per cent in L. douglas11). (21) Femur/t1blotarsus 72-74 per cent (76-77 per cent in I. douglas11). (22) Tarsometatarsus/femur 76-79 per cent (82 per cent in L. gembel11). (23) Humerus/fewur 83-85 per cent (79-80 per cent in L. cal1fornica). (24) Humerus/t1biotarsus 58.60 per cent 
(64-65 per cent 1n L. douglasi1). (25) Ulna/t1blotarsus 50-53 per cent (55-56 per cent in L. douglas11). (26) vina/ tarsometatarsus 87-90 per cent (97 per cent 1n L. douglas11). (27) Carpometacarpus/femur 45 per cent $(37-42$ per cent in L. cal1forn1ca). (28) Carpometacarpus/t1biotarsus 31-32 jer cent (34-35 per cent in L. douglas11). (29) Carpometacarpus/tarsometatarsus 54-56 per cent (59-60 per cent in L. douglas11). (30) Tarsometatarsus/humerus 98-99 per cent (89-90 per cent in L. douglasi1).

Remarks.--On the basis of the samples studied, the skeletons of the Becent species of Lophortyx show more interspeciflc differences than do those of Recent specles of., Col1nus. Lophortyx cal1forn1ca resembles L. gambel11 in 11 of 30 characters, L. douglasi1 in elght of 30 characters, and is unique in 11 characters. Lophortyx gambel11 resembles L. cal1fornica in 11 of 30 characters, L. douglasil in 10 or 30 characters, and 18 unique in nine characters. L. douglasil resembles L. californica in eight of 30 characters, L. Eambel11 in 10 of 30 characters, and is unlque in 12 of 30 characters.

Lophortyx californtca and L. gambeli1 are sim1lar in size, but L. douglasil averages somewhat smaller in most measurements (Table ?).

Odontophorus vie1llot 1816

The genus Odontophorus is confined to tropical America. 
S1xteen specles are recognized, of which 0 . gujanens1s (Gmelin 1789), 0. stellatus (Gould 1843), and 0. guttatus (Gould 1838) were examined. Table 7 includes measurements of these species.

Bostrum.--(1) Relatively long and shallow. (2) Nasel fossae ell1ptical.

Sternum..- (3) Helght of carlna through stemal plate $29-33$ per cent length of sternum (Table 3). (4) Dorsal 11p of coracoldal sulcus projected slightly, or well beyond ventral 11p. (5) Depressions on anterior portion of sternal plate obsolete and non-pneumat1c. (6) Base of posterior lateral process less than one-half wlath of sternal plate at its middle.

Coraco1d.--(7) Entire proximal end stralght above procoracold process. (8) Head narrowly rounded, moderately compressed, and moderately reflected or 1nflected. (9) Brach1al tuberosity w1th slight or moderate dorsal, and slight ventral overhang. (10) Furoular facet much inflated. (11) Blc1p1tal attachment well developed with margin between 1t and head concave. (12) Shaft wide proximally, with distal portion of 1 ts ventral surface concave medlally. (13) Procoracold process w1th 1 ts apex rounded. (14) Dorsal 1ntermuscular line swlnglng out to medial surface of shaft w1th distal two-thirds or d1stal three-fourths sharply ralsed. (15) Ventral intermuscular line terminating at tip of sternocoracoldal process. (16) Dorsal race moderately or deeply 
excavated distally, and without fossa. (17) Tubercle for ligamentum sterno-coracoldeum dorsale obsolete and 1rregular in shape. (18) Internal distal angle without distinct tubercle or ridge on dorsal face. (19) Sterno_coracoldal process with distal margin slightly oblique not produced as a sharply ralsed ridge, and without dorsal groove; with 1 ts tip directed laterally, and ending in a terminal knob. (20) D1stal border of sternal facet shallowly or deeply concave.

Scapula.--(21) Glenold facet oval or elliptical in dorsal view. (22) Dorsal depression just mediad to glenold facet shallowly to deeply excavated. (23) Brldge between acromion process and glenold facet usually about one-half width of glenold facet. (24) Acromion process w1 th 1 ts apex rounded and alightly or moderately deflected.

Humerus.-- (25) Pneumatic fossa short to moderately long, oval or elliptical, without lnner shelf, or with perforated lnner shelf extending from external bicipltal surface to medlal bar. (26) Median crest strongly or very strongly developed, elevated throughout. (27) Capital groove moderately excavated, with 1ts internal margin moderately elevated. (28) Margin between head and internal tuberosity moderately concave. (29) Head broader than long in anconal view. (30) Blige along medial border of fossa II moderately swollen, elongate, and with 1 ts apex acute. (31) Fossa II obsolete. (32) Latissimus ridge originating 
on lateral edge of shaft, but swinging in onto anconal face proxlmally. (33) External tuberosity slightly, moderately, or much 1nflated. (34) Blc1pital crest arising gently from shaft, rounded, and with 1ts distal border lacking a groove. (35) Deltold crest moderately or strongly developed, slightly inflected, and w1th lts summlt knob-like. (36) Enteplcondyle produced slightly beyond level of internal condyle. (37) Enteplcondylar prominence much produced, w1th Its pit placed on internal face. (38) Depression of M. brachlalls ant1cus moderately excavated. (39) Distal border of external condyle rounded in anconal view.

UIna.--(40) Olecranon process strongly produced, and w1th 1 ts apex polnted. (41) External cotyla moderately elongate, rounded throughout or plattened dorsally, with 1ts distal border sloping gently or precipltously into sheft, and slightly or deeply notched by proximal radial 1mpression. (42) Impression for M. brachlalls anticus excavated, with 1 ts borders distinct. (43) Helght at middle of shaft $65-72$ per cent of helght just d1stal to external cotyla. (44) D1stal radial Impression obsolete or moderately excavated. (45) Notch between carpal tuberosity and Internal condyle well developed. (46) External condyle well produced, arising abruptly from shaft, and rounded throughout. Carpometacarpus.--(47) Metacarpal I moderately polnted terminally. (48) Bloge separating anterior carpal fossa from excavated area above p1siform process produced, and 
extends well onto base of metacarpal I. (49) P1siform process ovalo1d in lnternal view, slightly reflected dorsad, thus slightly below level of dorsal rim of inner cerpal trochlea. (50) Ligamental attachment of pisiform process produced and moderately or much swollen proximally, flattened distally, with proximal portion elther connected to pisiform process by bony bridge or separated from p1s1form process by shallow sulcus. (51) Internal carpal trochlea with 1ts proximal border usually slightly notched, and Its ventral border w1 thout notch. (52) Internetacarpal tubercle extending to but not ankylosing with metacarpal III, and distally placed with a small space between Its posterlor border and junction of metacarpals II and III. (53) Tubercle on Internal proximal face of metacarpal III obsolete. (54) With one strongly developed tubercle on external proximal face of metacarpal III. (55) Metacarpal III slightly bowed. Pelv1s..--(56) Width of pelvis through ant1trochanters $51-53$ per cent of length of innominate from anterlor edge of 121um to 18chial angle (Table 3). (57) Pectineal process obsolete, only slightly produced beyond acetabular border as a mute polnt. (58) Depression on medial side of pectineal process obsolete, and without foramen. (59) Posterior $111 a c$ orest usually without prominence. (60) Ridge origlnating on posterior 1liac crest at level of 1110-111ac fenestra, and cont1nuing ventrad and posteriad towards posterior border of llium with prominence weakly 
or sharply arising from 1ts posterior portion; or pelvis without this ridge or prominence. (61) Dorsal face of post_acetabular 111um moderately broad anterlad, narrowing posterlad to form rounded or pointed apex of moderately or much elongated and narrow doxisal roof of posterion process. (62) Caudal face or post_acetabular 111um obsolete, triangular, and horlzontal in position, and forming ventral floor of posterior process. (63) Lateral face of post_acetabular lilum with 1 ts postero-dorsal apex acute, and forming moderately or much elongated lateral wall of posterlor procesa. (64) Renal bar broad, with bar, but not posterlor process excavated by renal depression. (65) Ischium at angle of about 160 degrees to ventral edge of posterior 111 ac crest. (66) W1ath through transverse processes of fourth synsacral vertebra 71-79 per cent length of synsacrum from centrum of flrst syosacral vertebra through transverse process of fourth synsacral vertebra. Femur.-- (67) Distal width $17-19$ per cent of length. (68) Head moderately enlarged, nelther bent dorsally nor rotated posterioriy. (69) Neck only moderately long. (70) Illao facet without compression, with posterlor border convex. (71) Dorsal crest of trochanter depressed and deflected, with 1 ts dorsal border flat. (72) Trochanteric rldge 21-26 per cent length of femur (Table 5). (73) D1stal depth 83-85 per cent of distal width. (74) Internal condyle moderately wide, and with 1 ts anterior border much 
produced throughout. (75) External condyle compressed, and rounded anteriorly.

T1blotarsus.--(76) Depth of 1nuer cnemlal crest 58.68 per cent of 1 ts length (Table 4). (77) Outer cnemial crest straight. (78) Interarticular tubercle moderately or strongly produced. (79) Area between external articular surface and outer cnemial crest moderately or deeply concave in dorsal view. (80) Posterior margin between external and 1nternal articular surface with a distinct notch. (81) Area Just anterior to ridge for proximal internal 11gamental attachment w1 thout deeply excavated depression. (82) Internal 11 gamental prominence on Internal condyle moderately produced. (83) Face of Internal conayle moderately excavated, w1th 1 ts border moderately elevated. (84) Dorsal border of supratendinal bridge usually stralght.

Tarsometatarsus.---(85) D1stal w1dth $17-18$ per cent of length (Table 6) (86) Proxlmal depth $96-100$ per cent of proximal width. (87) Intercotylar prominence moderately deflected, and with 1ts apex polnted. (88) Posterior intercotylar area moderately excavated as a triangular depression. (89) Area surrounding posterior opening of lnner proximal foramen usually very deeply excavated. (90) Hypotarsus w1th two well developed and one obsolete calcaneal ridges, two calcaneal grooves, and one or two closed calcaneal canals. (91) Anterior metatarsal groove reduced. (92) Depth of middle trochlea $54-57$ per cent of distal w1dth. 
(93) Trochlea for diglt II only slightly inflected. (94) Wing of trochlea for diglt IV depressed anteroposter1orly, thus entlre trochlea slightly longer than deep.

Intermembral proport1ons..-- (95) W1ng/leg $64-68$ per cent (Table 2). (96) Ulna/humerus 96-102 per cent. (97) Tarsometatarsus/femur 84-87 per cent. ( 98 ) Tarsometatarsus/t1blo_ tarsus 63-65 per cent. (99) Humerus/femur $82-86$ per cent. (100) Humerus/t1b1otarsus 61-64 per cent. (101) 01na/femur 80.85 per cent. (102) Ulna/t1b1otarsus 60_62 per cent. (103) U1na/tarsometatarsus 92-99 per cent. (104) Carpometacarpus/femur $47-49$ per cent. (105) Carpometacarpus/ t1blotarsus 33-36 per cent. (106) Carpometacarpus/tarsometatarsus 51-58 per cent. (107) Tarsometatarsus/humerus 99-101 per cent. (108) Il1um/sternum 71-76 per cent. (109) Helght of sternal car1na/111un $41-44$ per cent.

\section{Spec1f10 Varlat1on in Odontophorus}

Sternum.--(1) Helght of carina through sternal plate 32-33 per cent length of sternum (29 per cent length of sternum in 0 . guttatus). (2) Dorsal ip of coracoldal sulcus projected well beyond ventral 11p (projected only slight. Iy beyond ventral ilp in 0 . gujanens 1s).

Coracold.-- (3) Head moderately reflected (moderately inflected in 0 . guttatus). (4) Brachlal tuberosity with moderate dorsal overhang (slight dorsal overhang in 0 . gujanens1s). (5) Dorsal Intermuscular line with distal 
three-fourths sharply ralsed (w1th distal two-thirds sharply raised in 0. guttatus). (6) Dorsal face deeply excavated distally (moderately excavated distally in 0 . stellatus). (7) Distal border of sternal facet shallowly concave (deeply concare in 0 . guttatus).

Scapula.--(8) Glenold facet oval in dorsal view (elliptical in 0 . guttatus). (9) Dorsal deoression Just mediad to glenold facet moderately or deeply excavated (shallowly excavated in 0 . stellatus). (10) Acromion process w1th 1 ts apex only slighly deflected (moderately deflected in 0 . guttatus).

Humerus.--(11) Pneumat1c fossa oval, and w1thout inner shelf (elliptical, w1th a perforated inner shelf extending from external biclpital surface to medial bar in 0 . gujanens18). (12) Median crest strongly developed (very strongly developed in 0 . gujanens1s). (13) External tuberosity slightly irflated in 0 . guttatus moderately inflated 1n 0 . stellatus, much inflated in 0 . gujanensis. (14) Deltold crest moderately developed (strongly developed in 0 . Eujanens1s).

UIna.--(15) External cotyla rounded throughout (flattened dorsally in 0 . Buttatus), w1th 1 ts distal border sloping gently into shaft (sloping prec1pitously into shaft 1n 0 . guttatus), and only slightly notched by proximal radial impression (deeply notched by proximal radial Impression in 0 . gujanens1s). (16) D1stal radial 1mpression 
obsolete (moderately excavated in 0. gujanens1s).

Carpometacarpus.--(17) L1gamental attachment of p181_ form process much swollen proximally (moderately swollen proximalzy in 0 . Eujonens 1s).

Pelv1s.--(18) B1dge or1ginating on posterior $121 \mathrm{ac}$ crest at level of 1110-1schlac fenestra, and cont1nu1ng ventrad and posteriad towards posterlor border of 111 um w1th prominence sharply arising from its posterior portion in 0 . guttatus (prominerce weakly arising in 0 . stellatus, sharply arising, or w1thout ridge and prominence in 0. gujanens1s). (19) Dorsal face of post_acetabular 111 um much elongated and aarrow, and w1th 1ts apex polnted (moderately elongated and narrow, w1th 1 ts apex rounded in 0 . stellatus). (20) Lateral face of post-acetabular 111 um much elongated (moderately elongate in 0 . guttatus).

T1blotarsus.--(21) Depth of 1nner cnemial crest 65-68 per cent of 1 ts length ( 58 per cent of 1 ts length in 0 . gujanensis). (22) Interarticular tubercle moderately produced (strongly produced in 0 . stellatus). (23) Area between external articular surface and outer cnemial crest deeply concave in dorsal view (moderately concave in 0 . gujanensis). Tarsometatarsus.--(24) Hypotarsus w1th one closed calcaneal canal in 0 . stellatus (one or two in 0 . Euganensis, two in 0. guttatus).

Intermembral proportions.--(25) W1ng/leg 67-68 per cent ( 64 per cent in 0 . guttatus). (26) Carpometacarpus/humerus 
57 per cent ( 54 per cent in 0 . guttatus). (27) Tarsometatarsus/t1b1otarsus 63 per cent (65 per cent 1n 0 . guttatus). (28) Humerus/femur 84-86 per cent (82 per cent in 0 . guttatus). (29) UIna/remur $83-85$ per cent ( 80 per cent in 0 . guttatus). (30) U2na/tarsometatarsus 98-99 per cent (92 per cent in 0 . guttatus). (31) Carpometacarpus/femur $47-49$ per cent ( 45 per cent in 0 . guttatus). (32) Carpometacarpus/ t1blotarsus 35-36 per cent (33 per cent in 0. guttatus). (33) Carpometacarpus/tarsometatarsus 55-58 per cent (51 per cent in 0 . guttatus). (34) Illum/sternum 74-76 per cent (71 per cent in 0 . guttatus).

Bemarks.--As in skeletons of Recent Lophortyx, those of Odontophorus show more interspeclfic differences than do those of Becent species of Col1nus. Odontophorus guttatus differs from 0 . guganens $1 \mathrm{~s}$ and 0 . stellatus in many 1nterwembral ratios, and thus it has many more unlque characters than these forms. Odontophorus gujanens1s resembles 0 . stellatus in 19 of 33 characters. O. guttatus in three of 33 characters, and 18 unlque in 11 of 33 characters. Odontophorus stellatus resembles 0 . gujanensis in 19 of 33 characters, 0 . guttatus in 10 of 33 characters, and 18 unique 1n four of 33 characters. 0. guttatus resembles 0 . stellatus 1n 10 of 33 characters, 0 . gujanens1s in three of 33 charecters, and is unique in 20 of 33 characters.

According to the small avallable sample, the skeletons

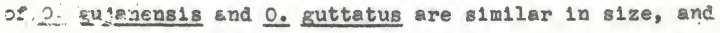


slightly larger than 0 . stellatus.

Dactylortyx Ov11v1e-Grant 1893

The single specles of this genus, Dactylortyx thoraclcus (Gambel 1848) is confined to Mexico and northern Central America, malnly in the mountains.

Bostrum.--(1) Relatively long and shallow. (2) Nasal fossae ell1ptical.

Sternum.-- (3) Helght of carlas through sternal plate 31-34 per cent length of sternum (Table 3). (4) Dorsal 11p of coracoldal sulcus even with or projecting only slightly beyond ventral 11p. (5) Depressions on anterior part of sternal plate shallow or obsolete, and non-pneumatic.

(6) Base of posterior lateral process less than one-half with of sternal plate at 1 ts midale.

Coracold.--(7) Ent1re proximal end stralght above procoracold process. (8) head narrowly rounded moderately compressed, and moderately inflected. (9) Brachlal tuberosity w1th slight dorsti? and ventrol overhang. (10) Furcular facet moderately inflated. (11) Blclpital attachment well developed, w1th margin between 1 and head concave. (12) Shaft wide proximally with alstal portion of 1 ts ventral surface concave medially. (13) Procoracold process with 1ts apex rounded. (14) Dorsal Intermuscular I1ne swinging out to medial surface of shaft, with distal three-fourths sharply ralsed. (15) Ventral intermuscular I1ne terminating at tip 
of sterno-coracold process. (16) Dorsal face deeply excavated distally and w1 thout fossa. (17) Tubercle for $11 \mathrm{ga}$ mentum sterno-coracoldeum dorsale usually obsolete and always 1rregular in shape. (18) Internal distal angle without distinct tubercle or ridge. (19) Sterno-coracoldal process w1th distal margin slightly oblique, not produced as a sharply ralsed ridge, and w1thout dorsal groove, w1th its t1p alrected laterally, and ending in a terminal knob. (20) Distal border of sternal facet deeply concave. Scapula.--(21) Glenold facet oval in dorsal view. (22) Dorsal depression just mediad to glenold facet shal_ lowly excavated. (23) Brldge between acromion process and gleno1d facet about one-half w1dth of glenold facet. (24) Acromion process with 1 ts apex rounded, and w1th slight to moderate deflection.

Humerus.-- (25) Pneumatic rossa short to moderately long ell1pse or ovalo1d w1thout Inner shelf. (26) Median crest strongly developed, elevated only at 1ts miade. (27) Cap1tal groove noderately excavated, w1th 1 ts 1 nternal margin moderately elevated. (28) Margin between head and Internal tuberusity moderately concave. (29) Head broader than long in anconal view. (30) Blage along medial border of fossa II much swollen, shortened, and w1th 1 ts apex rounded. (31) Fossa II well developed. (32) Lat1ss1mus ridge orlginating on lateral edge of shaft, but swinging in onto anconal face proximally.

(33) External tuberosity 
moderately inflated. (34) Blolpital crest arising gently from shaft, polnted, and with 1 ts distal border lacking a groove. (35) Deltold crest moderately developed, slightly inflected, and with its summit knob-like. (36) Enteplcondyle usually at level of Internal condyle. (37) Enteplcondylar prominence much produced, w1th 1 ts p1t usually placed on Internal face. (38) Depression of M. brachialis anticus shallowly excavated. (39) D1stal border of external condyle rounded in anconal view.

$$
\text { UIna.--(40) Olecranon process strongly produced, and }
$$
w1th 1 ts apex truncated. (41) External cotyla moderately elongate, rounded throughout, w1th 1 ts distal border loping gently Into shaft, and only glightly notched by proximal radial 1mpression. (42) Impression for M. brach1al1s ant1cus excovated, w1th 1 ts borders distinct. (43) belght at middle of shaft 71 per bent of helght just d1stal to external cotyla (Table 4). (44) Distal radial impression obsolete. (45) Notoh between carpal tuberosity and internal condyle well developed. (46) External condyle moderately produced, usually arlsing abruptly from shaft, and usually rounded throughout.

Carpometacarpus.--(47) Metacarpal I usually rounded terminally. (48) Rldge separating anterior carpal fossa from excavated area above p1siform process produced, and exterds well onto base of metacarpal I. (49) P1siform process ovalo1d in internal view, slightly reflected dorsad, 
thus below level of dorsal rim of inner carpal trochlea. (50) L1gamental attachment of pls1form process produced and much swollen proximally, flattened distally, with proximal portion connected to plsiform process by bony bridge. (51) Internal carpal trochlea w1th 1ts proximal border slightly notched, and 1 ts ventral border w1thout notch. (52) Intermetacarpal tubercle extending to but not ankylosing with metacarpal III, and proximally placed with only a minute space between Its posterlor border and junction of metacarpals II and III. (53) Tubercle on Internal proximal face of metacarpal III obsolete. (54) W1th one moderately developed tubercle on external proximal face of metacarpal III. (55) Metacarpal III sl1ghtly bowed. Pelv18.--(56) W1dth of pelvis through ant1trochanters 55-58 per cent length of Innominate from anterior edge of 111um to 1schlal angle (Table 3). (57) Pectineal process absent, or obsolete and only sllghtly produced beyond acetabular border as a m1nute polnt. (58) Depression on medial slde of pectineal process absent. (59) Posterior 111 ac crest with prominence moderately produced from just posterior to 1110-1schiac fenestra. (60) W1thout ridge or prominence ventral to posterior 1118 crest. (61) Dorsal face of post-, acetabular lilum moderately broadened anterlad, narrowlng gently posteriad to form truncated apex of moderately long, narrow dorsal roof of posterior process. (62) Caudal face of post_acetabular 111um obsolete, rectangular, and horlzontal 
in position, and forming ventral floor of posterior process. (63) Lateral face of post-acetabular 111um with 1ts posterodorsal apex acute, and forming elongate lateral wall of posterior process. (64) Renal bar broad, w1th bar, but not posterior process excavated by renal depression. (65) Isch1um at angle of about 160 degrees to ventral edge of posterior 111ac crest. (66) Width through transverse process of fourth synsacral vertebra $88-93$ per cent of length of synsacrum from centrum of flrst synsacral vertebra through transverse process of fourth synsacral vertebra. Femur.--(67) D1stal width 19 per cent of length (Table 5). (68) Head much enlarged, nelther bent dorsally nor rotated posterlorly. (69) Neck only moderately long. (70) Illac facet w1thout compression, w1th posterior border convex. (71) Dorsal crest of trochanter compressed and reflected, with 1 ts dorsal border rounded. (72) Trochanteric r1dge 15-18 per cent length of femur. (73) D1stal depth $81-84$ per cent of distal width. (74) Internal condyle narrow, and with 1 ts anterior border usually weakly produced throughout. (75) External condyle compressed, and rounded anteriorly.

T1blotarsus.--(76) Depth of Inner cnemlal crest $42-48$ per cent of 1 ts length (Table 4). (77) Outer cnemlal crest stra1ght. (78) Interarticular tubercle weakly produced. (79) Area between external arțcular surface and outer cnemial crest very deeply concave in dorsal view. (80) Pos.. 
terior margin between external and internal articular surface with a distinct notch. (81) Area just anterior to ridge for proximal internal ligamental attachment without deeply excarated depression. (82) Area of Internal ligamental attachment on Internal condyle not produced as a prominence. (83) Face of internal condyle moderately excavated, w1th 1 ts border moderately elevated. (84) Dorsal border supratendinal bridge stralght.

Tarsometatarsus.--(85) D1stal w1dth 19-2l per cent of length (Table 6). (86) Proximal depth 88-94 per cent of proximal width. (87) Intercotylar prominence only slightly deflected, and with 1 ts apex usually polnted. (88) Posterior intercotylar area moderately excavated as a triangular depression. (89) Area surrounding posterior opening of lnner proxtmal foramen moderately excavated. (90) Hypotarsus w1th two well developed and one weakly developed cal_ caneal ridges, two calcaneal grooves, and two closed calcaneal canals. (91) Anterior metatarsal groove reduced or obsolete. (92) Depth of middle trochlea 45-50 per cent of distal width. (93) Trochlea for diglt II moderately inflected. (94) Wing of trochlea for diglt IV depressed dorsoventrally, thus entire trochlea much deeper than long.

Intermembral proportions.-- (95) W1ng/leg 72-73 per cent (Table 2). (96) Ulna/humerus $98-100$ per cent. (97) Tarsometatarsus/femur $81-82$ per cent. (98) Tarsometatarsus/tiblotarsus 59-60 per cent. (99) Humerus/fenur 90-91 
per cent. (100) Humerus/t1b1otarsus 66-67 per cent. (101) Ulna/femur 88-91 per cent. (102) U1na/t1blotarsus 65-66 per cent. (103) v1na/tarsometatarsus 109-111 per cent. (104) Carpometacarpus/femur 48-50 per cent. (105) Carpometacarpus/tiblotarsus 35-36 per cent. (106) Carpometacarpus/tarsometatarsus 59-62 per cent. (107) Tarsometatarsus/humerus 90 per cent. (108) Illum/sternum 70-78 per cent. (109) Helght of sternal carlna/111um $40-49$ per cent.

\section{Cyrtonyx Gould 1844}

The genus Cyrtonyx is confined to the mountains of the southwestern United States, Mexico, and northern Central America. Three specles are reoognized, of whlch C. montezumae (V1gors 1830) was examined.
Bostrum.--(1)
(1) Relatively long and shallow.
(2) Nasal fossae elliptical.

Sternum.-- (3) Helght of carina through sternal plate 28-32 per cent length of sternum (Table 3). (4) Dorsal 11p of coracoldal sulcus usually projected well beyond ventral 11p. (5) Depressions on anterior part of sternal plate shallow and non-pneumatic. (6) Base of posterlor lateral process less than one-half w1dth of sternal plate at 1ts midale.

Coracold.--(7) Ent1re proximal end stra1ght above procoracold process. (8) Head narrowly rounded, moderately compressed, and moderately inflected. (9) Brachial tuber- 
OB1ty w1th slight dorsal and ventral overhang. (10) Furcular facet obsolete. (11) Blclpltal attachment well developed, w1th margin between 1t and head concave. (12) Shaft wide proximally, w1th distal portion of 1 ts ventral surface usually convex medially. (13) Procoracold process with 1ts apex rounded. (14) Dorsal Intermuscular line swinglng out to medial surface of shaft, w1th distal half sharply ralsed. (15) Ventral intermuscular I1ne terminating at tip of sternocoraco1d process. (16) Dorsal face deeply excavated d1stally, and without fossa. (17) Tubercle for ligamentum sterno-coracoldeum dorsale usually well developed and rounded. (18) Internal distal angle without distinct tubercle or ridge on dorsal face. (19) Sterno-coracoldal process with distal margin slightly oblique, not produced as à sharply ralsed ridge, and w1thout dorsal groove; with 1ts tip directed laterally, and ending in a terminal kwob. (20) D1stal border of sternal facet deeply concave. Scapula.--(21) Glenold facet oval in dorsaz view. (22) Dorsal depression just mediad to glenold facet obsolete to shallowly excavated. (23) Bridge between acromion process and glenold facet about one-half width of glenold facet. (24) Acromion process with 1ts apex rounded, and very strongly derlected.

Humerus.--(25) Pneumatio fossa a moderately long ellipse or ovalo1d, w1thout 1nner shelf. (26) Median crest strongly developed, elevated only at 1ts midale. (27) Cap1- 
tal groove moderately excavated, with 1ts laternal margin moderately elevated. (28) Margin between head and luternal tuberosity woderately concave. (29) Head broader than long 1n anconal view. (30) Rldge along medial border of fossa II moderately swollen, elongate, and with 1 ts apex acute. (31) Fossa II well developed. (32) Lat1ssimus ridge orig1nating on lateral edge of shart, but swinging in onto anconal face proximally. (33) External tuberosity moderately 1nflated. (34) Blclpltal crest arlsing gently from shaft, polnted, and with 1ts distal border lacklag a groove. (35) Deltoid crest moderately developed, slightly lnflected, and with 1 ts summt knob-like. (36) Enteplcondyle produced slightly beyond level of Internal conåyle. (37) anteplcondylar promlnence moderately produced with its pit placed on palmar face. (38) Depression of M. brachlalis anticus shallowly excavated. (39) Distal border of external condyle rounded in anconal view.

Ulna.--(40) Olecranon process strongly produced, with 1ts apex polnted. (4I) External cotyla moderately elongate, rounded throughout, with 1ts distal border sloplng gently into shaft, and only slightly notched by proximal radial 1opression. (42) Impression for M. brechlalls antious excavated, with its borders distinct. (43) Helght at middle of shaft 60.63 per cent of height just distal to external cotyla (Table 4). (44) Distal radial 1mpression obsolete. (45) Notch between carpal tuberosity ana Internal conciyle 
well developed. (46) External condyle moderately produced, usually ar1sing abruptly from shaft, and usually rounded throughout.

Carpometacarpus...-(47) Metacarpal I usually moderately polnted terminally. (48) Bldge separating anterior carpal fossa from excavated area above pisiform process produced, and extends well onto base of metacarpal I. (49) PIs1form process oval or ovaloid in internal view, slightly reflected dorsad, thus usually below, occaslonally at level of dorsal rim of lnner carpal trochlea. (50) Ligamental attachment of p1s1form process produced and moderately swollen proximally, flattened distally, with proximal portion connected to pls1form process by bony bridge. (51) Internal carpal trochlea with 1 ts proximal border shallowly concave, and 1ts ventral border w1thout notch. (52) Intermetacarpal tubercle not reaching or barely extending to metacarpal III, and alstally placed w1th a small space between 1 ts posterior border and Junction of metacarpals II and III. (53) Tubercle on 1nternal proximal face of metacarpal III elongate and moderately produced. (54) W1 th one obsolete to weakly developed tubercle on external proximal face of metacarpal III. (55) Metacarpal III slightly bowed.

Pelv1s.--(56) W1dth of pelv1s through ant1trochanters 50-54 per cent length of Innominate from anterlor edge of 111um to 1schial angle (Table 3). (57) Pectineal process obsolete, only slightly produced beyond acetabular border as 
a minute point. (58) Depression on medial side of pectineal process obsolete, and w1 thout foramen. (59) Posterlor 111 ac crest with prominence strongly produced from just posterior to 1110-1schlac fenestra. (60) W1thout ridge or prominence ventral to posterior $111 \mathrm{ac}$ crest. (61) Dorsal face of postacetabular 1l1um narrow anterlad, further narrowing gently posterlad to form polnted apex of much elongated, narrow, dorsal roof of posterior process. (62) Caudal face of postacetabular 1l1um, obsolete, narrowly trlangular, horlzontal In position, and forming ventral floor of posterior process. (63) Lateral face of post-acetabular 111um w1th 1 ts posterodorgal apex much polnted, and forming much elongated lateral wall of posterlor process. (64) Renel bar broad, with bar, but not posterior process excavated by renal depression. (65) Ischlum at angle of about 145 degrees to ventral edge of posterior 111ac crest. (66) W1dth through transverse processes of fourth synsacral vertebra 67-71 per cent of length of synsacrum from centrum of first syasacral vertebra throug:l transverse process of fourth synsacral vertebra. Femur.--(67) Distal w1dth 17-19 per cent of length (Table 5). (68) Head moderately enlarged, nelther bent dorsally nor rotated posterlorly. (69) Neck short. (70) Illac facet w1thout compression, w1th posterior border convex. (71) Dorsal crest of trochanter depressed and deflected, with 1 ts dorsal border flat. (72) Trochanterid r1dge 23-25 per cent length of femur. (73) D1stal depth 
75-79 per cent of distal width. (74) Internal condyle moderately w1de, and with 1 ts anterior border usually weakly produced throughout. (75) External condyle compressed, and rounded anterlorly.

Tiblotarsus.--(76) Depth of 1nner cnemlal crest 37-46 per cent of 1 ts length. (77) Outer onemlal crest usually stralght. (78) Interarticular tubercle weakly produced. (79) Area between external articular surface and outer cuemial crest moderately concave in dorsal view. (80) Posterior margin between external and Internal articular surface with a dstinct notch. (81) Area just anterior to ridge for proximal internal ligamental attachment w1 thout deeply excavated depression. (82) Internal 11gamental prominence on internal condyle moderately produced. (83) Face of 1aternal condyle moderately excavated, with 1 ts border moderately elevated. (84) Dorsal border of supratendinal bridge straight.

Tarsometatarsus.---(85) D1stal w1dth 21-22 per cent of length (Table 6). (86) Proximal depth 95-98 per cent of proximal w1dth. (87) Intercotylar prominence moderately deflected, and with 1 ts apex pointed. (88) Posterlor 1ntercotylar area usually moderately excavated as a trlangular depression. (89) Area surrounding posterior opening of 1 nner proximal foramen moderately excavated. (90) Hypotarsus with two well developed and one obsolete calcaneal ridges, two calcaneal grooves, and two closed calcaneal cansls. 
(91) Anterlor face of shaft usually moderately excavated by anterlor metatarsal groove. (92) Depth of -midale trochlea 46-58 per cent of d1stal w1dth. (93) Trochlea for alg1t II moderately inflected. (94) Wing of trochlea for diglt IV depressed dorsoventrally, thus ent1re trochlea much deeper than long.

Internembral proport1ons.--(95) Wing/leg 78-81 per cent (Table 2). (96) Ulna/humerus 93-94 per cent. (97) Tarsometatarsus/femur 70-73 per cent. (98) Tarsometatarsus/t1blotarsus 53-56 per cent. (99) Humerus/femur 95-101 per cent. (100) Humerus/t1blotarsus 72-75 per cent. (101) U1na/femur 88-93 per cent. (102) U1na/tiblotarsus 68-71 per cent. (103) Una/tarsometatarsus 126-133 per cent. (104) Carpometacarpus/femur 50-52 per cent. (105) Carpometacarpus/ tiblotarsus 38-40 per cent. (106) Carpometacarpus/tarsometatarsus $71-74$ per eent. (107) Tarsometatarsus/humerus 70-74 per cent. (108) Il1um/sternum 72-76 per cent. (109) Helght of sternal car1na/111um $38-41$ per cent.

\section{Rhynchortyx Og1lv1e-Grant 1893}

The wonotyplo genus Bhynchortyx occurs in the troplcal lowlands from Honduras to Ecuador. Measurements of B. clnctus (Salvin 1876) are Given in Table ?.

Bostrum.--(1) Short and deep. (2) Nasal fossae round. Sternum.-- (3) Helght of carina through sternal plate 35 per cent length of sternum. (4) Dorsal 11p of coracoldal 
sulcus projected only slightly beyond ventral 11p. Depressions on anterior portion of sternal plate deep and very pneumatic. (6) Base of posterior lateral process less than one-half width of sternal plate at its middle.

Coraco1d.-.-(7) Ent1re proximal ead stralght above procoracold process. (8) Head broadly rounded, much depressed, and moderately inflected. (9) Brachlal tuberosity with sl1ght dorsal, and obsolete ventral overhang. (10) Furcular facet obsolete. (11) B101p1tal attachment weakly developed, With margin between 1t and head stralght. (12) Shaft wide prozlmally, with distal portion of 1 ts ventral surface convex mediliy. (13) Procoracold process w1th 1ts apex rounded. (14) Dorsal Intermuscular 11ne swinging out to medial surface of shaft, with distal half sharply raised. (15) Ventral intermuscular Ine terminating at tip of sternocoracold process. (16) Dorsal face weakly excavated d1stally, and without fossa. (17) Tubercle for 11gamentum stemo-coracoldeum corsale obsolete, and 1rregular in shape. (18) Internal distal angle with distinct, but weakly developed dorsal riage extending obliquely to above lateral end of sternal facet. (19) Sterno-coracoldal process w1th distal margin moderately oblique, produced as a sharply ralsed ridge, and w1thout dorsal groove; w1th 1 ts t1p directed laterally, and ending in a terminal kaob. (20) Distal border of sternal facet deeply concave.

Scapula.--(21) Glenold facet oral in dorsal view. 
(22) Dorsal depression Just mediad to glenold facet obsolete. (23) Bridge between acromion process and glenold facet more than one-half width of glenold facet. (24) Acromion process with 1 ts apex truncated, and very slightly deflected.

\section{Humerus.-- (25) Pneumatic fossa a moderately long} ellipse, without 1nner shelf. (26) Median crest strongly developed, elevated only at 1 ts midale. (27) Capital groove moderately excavated, w1th 1 ts internal margin moderately elevated. (28) Margin between head and Internal tuberosity, moderately concave. (29) Head broader than long in anconal vlew. (30) Bldge along medial border of fossa II moderately swollen, elongate, and w1th 1 ts apex acute. (31) Fossa II well developed. (32) Lat1ssimus ridge orlginating on lateral edge of shaft, but swinglng in onto anconal face proximaliy. (33) External tuberosity moderately inflated. (34) B1c1p1tal crest arising abruptly from shaft, rounded, and w1th shallow groove in 1 ts distal margin. (35) Deltold crest moderately developed, slightly infleoted, and with 1ts summit knob-11ke. (36) Enteplcondyle at level of Internal condyle. (37) Enteplcondylar prominence much produced, with 1ts p1t placed on palmar face. (38) Scar for M. brachlal1s anticus w1 thout excavation. (39) D1stal border of external condyle rounded in anconal view.

UIna... (40) Olecranon process weakly produced, w1th 1 ts apex rounded. (4I) External cotyla moderately elongate, 
rounded throughout with 1 ts distal border sloplng gently Into shart, and deeply notched by proximal radial $1 \mathrm{~m}$ pression. (42) Impression for M. brachlalls anticus excavated, w1th 1 ts borders distinct. (43) Helght at middle of shaft 61 per cent of helght just distal to external cotyla (Table 4). (44) Distal radial 1mpression obsolete. (45) Notoh between carpal tuberosity and 1nternal condyle well developed. (46) External condyle weakly produced, arising very gently from shaft, and rounded throughout. Carpometacarpus.--(47) Metacarpal I moderately polnted terminally. (48) Bldge separating anterior carpal fossa from excavated area above plsiform process produced, and extends well onto base of metacarpal I. (49) P1siform process elliptical in internal view, slightly reflected dorsad, thus below level of dorsal rim of inner carpal trochlea. (50) Ligamental attachment of pisiform weakly produced and only slightly swollen proxlmally, flattened distaliy, with proximal portion connected to pisiform precess by bony bridge. (51) Internal carpal trochlea with 1ts proximal border shallowly concave and 1ts ventral border w1 thout notch. (52) Interwetacarpal tubercle extending to but not ankylosing w1th metacarpal III, and distally placed with a small space betwern $1 \mathrm{ts}$ posterlor border and junction of metacarpals II and III. (53) Tubercle on 1nternal proximal face of metacarpal III elongate and moderately produced. (54) W1th one obsolete tubercle on external proximal face 
of metacarpal III. (55) Metacarpal III slightly bowed. Pelvis..- (56) width of pelvis through antitrochanters 59 per cent length of Innominate from anterior edge of 11 um to 1schial angle (Table 3). (57) Pectineal process obsolete, only slightly produced beyond acetabular border as a minute point. (58) Depression on medial side of peotineal process obsolete, and without foramen. (59) Posterior $111 a c$ crest with prominence weakly produced from just posterior to 1210-1sch1ac fenestra. (60) w1thout ridge or prominence ventral to posterior 111 as orest. (61) Dorsal face of post-acetabular 111 um moderately broadened anteriad, narrowing gently posteriad to form truncated apex of moderately leng, narrow dorsal rocf of posterior process. (62) Caudal face of post_acetabular 111um obsolete, rectangular, and horizontal in position, and forming ventral floor of posterlor process. (63) Lat_ eral face of post-acetabular 111 um w1th 1 ts posterodorsal apex truncated, and forming moderately elongate lateral wall of posterlor process. (64) Renal bar broad, w1th bar slightly excavated, but posterior process unexcavated by renal depression. (65) Ischium at angle of about 160 de_ grees to ventral edge of posterior $111 a c$ crest. (66) W1dth through transverse processes of fourth synsacral vertebra 92 per cent length of synsacrum from centrum of flrst synsacral vertebra through transverse process of fourth syasacral vertebra. 
Feaur.--(67) D1stal w1dth 18 per cent of length (rable 5). (68) Head moderately enlarged, bent dorsally, but without posterior rotation. (69) Neck only moderately long. (70) Illac facet w1 thout compress1on, with posterior border convex. (71) Dorsal crest of trochanter obsolete, w1th 1ts dorsal border rlat. (72) Trochanteric ridge 12 per cent length of femur. (73) D1stal depth 71 per cent of distal width. (74) Internal condyle moderately wide, and with 1ts anterlor border much produced throughout. (75) External condyle compressed, and rounded anteriorly.

Tiblotarsus.-- (76) Depth of 1nner cnemial crest 75 per cent of 1 ts length (Trable 4). (77) Outer cnemlal crest decurved. (78) Interarticular tubercle moderately produced. (79) Area between external articular surface and outer cnemial crest moderately concave in dorsal view. (80) Posterior margin between external and Internal articular surface with distinot notch. (81) Area just anterior to ridge for proximal internal ligamental attachment without deeply excavated depression. (82) Area of Internal 11ga_ mental attachment on internal condyle not produced as a prominence. (83) Face of Internal condyle weakly excavated, with 1 ts border weakly elevated. (84) Dorsal border of supratendinal bridge oblique.

Tarsometatarsus.--(85) D1stal w1dth 16 per cent of length (Table 6). (86) Proximal depth 95 per cent of proximal width. (87) Intercotylar prominence depressed, 
without deflection, and with 1 ts apex broady rounded. (88) Posterior 1ntercotylar area unexcarated. (89) Area surrounding posterior opening of lnver proximal foramen shallowly excavated. (90) Hypotarsus with three well developed calcaneal ridges, two calcaneal grooves, and one closed calcaneal canal. (91) Anterior face of shaft extensively excavated by anterior metatarsal groove.

(92) Depth of midale trochlea 56 per cent of distal width. (93) Trochlee for d1glt II only slightly inflected. (94) W'1ng of trochlea for diglt IV depressed dorsoventrally, thus ent1re trochlea much deeper than long. Interwembral proportlons.-- (95) W1ng/leg 67 per cent (Table 2). (96) Ulna/humerus 98 per cent. (97) Tarsometatarsus/femur 88 per cent. (98) Tarsometatarsus/t1blotarsus 63 per cent. (99) Humerus/femur 85 per cent. (100) Fumerus/ t1blotarsus 61 per cent. (10I) U1na/femur 87 per cent. (102) U1na/t1blotarsus 62 per cent. (103) Ulna/tarsometa_ tarsus 99 per cent. (104) Carpometacarpus/fenur 48 per cent. (105) Carpometacarpus/t1blotarsus 34 per cent. (106) Carpometecarpus/tarsometatarsus 55 per cent. (107) Tarsometatarsus/humerus 203 per cent. (108) Il1um/ sternum 68 fer cent. (109) Helght of sternal cerina/121um 52 per cent.

Summary of Gener1c Characters

Inportant osteological characters of the New World 
qua1l include the four classes. (1) Characters of the pelvis that tend to divide the New World quall 1nto two major groups. An example of one of these characters 18 the poorly developed, slender, renal bar in Dendrortyx, Phllortyx, Oreortyx, Callipepla, Colinus, and Lophortyx, and the well developed, broad renal bar in Odontophorus, Dactylortyx, Cyrtonyx, and Rhynchortyx. (2) Primitive characters that are apparently hold-overs from less highly evolved groups. An example is the indistinct fossa II of the humerus as found in Dendrortyx and Odontophorus. (3) Characters that are unique in certaln genera. An example 1s the short, deep rostrum, with round nasal fossae, as found in Bhynchortyx. (4) Characters that are not unlque, but may be used in comblnation with other such characters for generic definition.

When character does not hold absolutely in the genus, but occurs in most individuals of the genus, the conditlon 1s modifled by the word "usually." Characters that hold in some genera, but vary speclfically or show much 1ndividual variation in other genera are 11sted as "varia_ ble." Characters that show much Individual varlation in all genera, and ratlos that would probably overlap in greater series, are omitted from the following section.

Bostrum.-.-The rostrum is relatively long and shallow, and the nasal fossae are elliptical in most New World qua1l. In Bhynchortyx the rostrum is much shorter and 
deeper, and 1 ts nasal fossae are round.

Sternum.--The dorsal 11p of the coracoldal sulcus projects well beyond the ventral ilp in most genera. In Dactylortyx the dorsal 11 p projects only slightly beyond the ventral 11p, and in Bhynchortyx the dorsal 11p 11es even with or projected only slightly beyond the ventral 11p. The character is variable in Cyrtonyx and Odontophorus. The depressions on the anterior portion of the sternal plate are deep and very pneumatic in Ehynchortyx, deep and moderately pneumat1o in Oreortyx, deep and slighly pneumatic in Philortyx, shallow and slightly pneumatic in Dendrortyx, usually shallow and non-pneumatio in Collnus, shallow and non-pneumatic in Cyrtonyx, shallow or obsolete and non-pneumatio in Dactylortyx, obsolete and non-pneumat1o in Odontophorus, and variable in Callipepla and Lophortyx.

The base of the posterior lateral process is narrow and less than one-half the width of the sternal plate at its middle in most genera, but it is wide, and more than one-half the w1dth of the sternal plate at 1ts midde in Dendrortyx.

Coraco1d.--The ent1re proximal end 1s stralght above the level of the procoracold process in most New World qua11, but 1t 1s bent ventrad above the level of the procoracold process in Dendrortyx.

The head is narrowly rounded and moderately compressed 
In most genera, but it is pointed and much compressed in Phllortyx, broadly rounded and much depressed in Dendrortyx and Rhynchortyx, and broadly rounded and moderately depressed in Oreortyx.

The head is moderately inflected in Callipepla, Lophortyx, Dactylortyx, Cyrtonyx, and Bhynchortyx, and much Inflected in Dendrortyx, but it 18 moderately reflected in Oreortyx, much reflected in philortyx, and variable in Col1nus and Odontophorus.

The brachial tuberosity has a slight dorsal and ventral overhang in most New World qua1l, but it has a moderate dorsal and slight ventral overhang in Dendrortyx, slight dorsal and obsolete ventral overhang in Bhynchortyx, an obsolete dorsal and slight ventral overhang in Philortyx, and is variable in Odontophorus.

The furcular facet is obsolete in Rhynchortyx and Cyrtonyx, weakly inflated in Dendrortyx, Philortyz, and Lophortyx, moderately inflated in Oreortyx, Callipepla, and Dectylortyx, mob inflated in Odontophorus, and variable in Colinus.

The biclpital attachment is well developed, with the margin between 1 t and the head concave in most genera, but In Rhynchortyx it is weakly developed and with the margin between 1 t and the head straight.

The procoracold process has 1 ts apex rounded in most New World quall, but it is acute in Phllortyx and 
Callipepla, and 1t is variable in Colinus.

The dorsal 1nterwuscular 11ne swings out to the medial surface of the shaft in most genera, but the line swlags out to the lateral border of the shaft in Dendrortyx. The distal half of the dorsal intermuscular line 18 sharply raised in most forms, but the sharply raised portion is confined to the distal three-fourths in Dectylortyx, the distal two-thirds or three-fourths in odontophorus, and only the distal one-fifth in Dendrortyx.

The ventral intermuscular ilne terminates at the tip of the sterno-coracoldal process in most genera. It term1nates in the midale of the distal border of the sternocoracoldal process in Denarortyx.

The dorsal face is weakly excavated distally in Dendrortyx, Philortyx, Oreortyx, Cal11pepla, and Rhyochortyx, moderately excavated distally in Collnus, deeply excavatea distalıy in Cyrtonyx and Dactylortyx, and varlable in Lophortyx and Odontophorus. The dorsal face lacks a distinut fossa in most genera, but has a distinct, round deep fossa below the tubercle for the I1 gamentum sterno-coracoldeum dorsale, and above the external end of the sternel facet in Dendrortyx.

The tubercle for the I1gamentum sterno-coracoldeum dorsale is obsolete and irregular in shape in Bhynchortyx and Odontophorus, obsolete and rounded in Dendrortyz and Call1pepla, well developed but 1rregular in shape in 
Oreortyx, well developed and rounded in Philortyx, end varlable in the other genera.

The internal distal angle is without a distinct tubercle or ridge in most New World qua1l. It has a distinct but 1rregular tubercle that extends obliquely to above the lateral end of the sternal facet in Oreortyx and Call1pepla. In Philortyx and Rhynchortyx it has a distinct oblique ridge, with this structure weakly developed in the latter genus.

The sterno-coracoldal process has 1ts distal margin slightly oblique, nelther produced as sharply ralsed rldge, nor grooved dorsally, and its tip is directed laterally and possesses a terminal knob in most New World quall. Philortyx differs in that the distal margin of the sternocoracoldal process 18 moderately oblique, Rhynchortyx in that the distal margin 18 moderately oblique, and produced as a sharply ralsed ridge, and Dendrortyx in that the distel margin 1s strongly oblique, grooved dorsally, with the tip of the sterno-coracoldal process directed proxime11y and without a terminal knob.

The distal border of the sternal facet 18 deeply concave 1n Oreortyx, Rhynchortyx, and Dactylortyx, usually deeply concave in Collnus, shallowly concave in Phllortyx, very shallowly concave in Dendrortyx, and varlable in the other genera.

Scapula.--The glenold facet is oval in dorsal view in 
most New World quall, but is elliptical in dorsal view in Dendrortyx, and variable in Odontophorus.

The bridge between the acromion process and glenold facet 18 about one-half the width of the glenold facet in most genera, but the bridge is about one-third the width of the glenold facet in Philortyx, and variable in collnus, Lophortyx, and Odontophorus.

The acromion process has its apex rounded in most New World qua11, but it is acute in Dendrortyx and Oreortyx and truncated in Rhynchortyx. The amount of deflection of the acromion process shows much variation within genus, but 1t 18 much more strongly deflected in Cyrtonyx than in the other forms.

The shape of the pneumatic fossa shows much variation w1thln genera of New World quall, but only one form, a species of Odontophorus, has a perforated 1 nner shelf that extends from the external bicipital surface to the medil bar.

The median crest is strongly or very strongly developed 1n Odontophorus, strongly developed in Dendrortyx, Oreortyx, Cyrtonyx, Rhynchortyx, and Dactylortyx, moderately to strongly developed in Collnus, usually weakly developed in Call1pepla, weakly developed in Phllortyx, and variable in Lophortyx. The median crest 18 elevated only at 1 ts middle in most genera, but is elevated throughout in Dendrortyx, Ph1lortyx, and Odontophorus, and variable in Lophortyx. 
The cap1tal groove 18 moderately excavated and its Internal margin is moderately elevated in most New World qua11, but 1t 1s deeply excavated with 1ts internal margin strongly elevated in Dendrortyx and Philortyx.

The margin between the head and Internal tuberosity is moderately concave in most genera but is nxiy sllghtly ooncave in Dendrortyx.

The head 18 broader than long in most New World quall, but it is about as long as broad in Dendrortyx and Philortyx, and is variable in Lophortyx.

The ridge along the medial border of fossa II is moderately swollen in Callipepla, Lophortyx, Odontophorus, Cyrtonyx, and Rhynchortyx, slightly to moderately swollen in Collnus, slightly swollen in Dendrortyx and Philortyx, and much swollen in Oreortyx and Dactylortyx. The rldge along the medil border of fossa II 1 s elongate and polnted 1n most genera, but 1t is short and rounded in Dectylortyx.

Fossa II 18 well developed in most forms but is obsolete in Dendrortyx and odontophorus.

The latissimus ridge orlginates on the lateral edge of the shaft and swings onto the anconal face proximally in most New World quall, but the rldge extends along the lateral edge of the shaft throughout 1 ts length in Dendrortyx.

The external tuberosity is moderately inflated in most forms, but it is much inflated in Oreortyx, and variable in Odontophorus. 
The blcipital crest arises gently from the shaft in most New World quall but arises abruptly from the shaft in Bhynchortyx. The blcipital crest is polnted in Philortyx, Oreortyx, Cyrtonyx, and Dactylortyx, usually narrowly rounded in Colinus, narrowly rounded in Call1pepla and Lophortyx, and rounded in Dendrortyx, Ehynchortyx, and Odontophorus. The blcipital crest lacks a groove in its distal margin in most forms, but hes a shallow groove in Bhynchortyx.

The deltold crest is moderately developed in most forms, but it is much developec in Dendrortyx, and variable in odontophorus. The deltold crest 18 slightly inflected. in most forms but is much inflected in Dendrortyx. The summit of the deltold crest is knob-11ke in most New World qua11, but 1t 18 usually flattened in Lophortyx, and variable in Colinus.

The enteplcondyle is at the level of the luternal condyle in Dendrortyx, Oreortyx, Cal11pepla, and Bhynchortyx, usually at the level of the internal condyle in Colinus and Dactylortyx, and produced slightly beyond the internal condyle in Philortyx, Lophortyx, Odontophorus, and Cyrtonyx. The enteplcondylar prominence $1 \mathrm{~B}$ weakly produced in Dendrortyx, moderately produced in Phllortyx, Oreortyx, Call1pepla, Collnus, Lophortyx, and Cyrtonyx, and much produced in Odontophorus, Daitylortyx, and Bhynchortyx. Tine p1t of the enteplcondylar prominence 18 placed on the 
1nternal face of the humerus in most forms, but it is placed on the palmar face in Callipepla, Cyrtonyx, and Bhynchortyx. The depression for the M. brachlalis anticus 1s deeply excsvated in Dendrortyx and Phllortyx, usually moderately excavated in Colinus, moderately excavated in Lophortyx and Odontophorus, usually shallowly excavated : a Calji.1pepla, shallowly excavated in Oreortyx, Cyrtonyx, and Dactylortyx, and represented by an unexcavated scar in Rhynchortyx. The distal border of the external condyle is rounded in anconal view in most New World qua11, but it is flat in anconal view in Dendrortyx.

UIna.-.The olecranon process is strongly produced in most New World quall but weakly produced 10 Phynchortyx. The apex of the olecranon process is polnted in most forms, but 1 it 18 rounded in Dendrortyx and Rhynchortyx, and truncated in Dactylortyx.

The external cotyla is moderately elongate in wost genera, but it is wuch elongated in Oreortyx, and shortened in Dendrortyx. The external cotyla is rounded throughout, and 1ts distal border slopes gently into the shart in most forms, but it is flattened dorsaliy with 1ts distal border sloping prec1pitously into the shaft in Dendrortyx, and It is variable in odontophorus. The external cotyla is slightly notched by the proximal radial impresiton in Oreortyx, Cal11pepla, Col1nus, Cyrtonyx, and Dectylortyx, usually slightly notched in Collnus, deeply notched in 
Dendrortyx, Philortyx, and Bhynchortyx, and is variable in odontophorus.

The 1mpreasion for the M. brachialis anticus is excavated with 1 ts $_{8}$ borders distinct in most New World qua1l, but it is represented by an uriezcavated scar with 1ndistinct borders in Philortyx.

The helght at the middle of the shaft in most New World qua11 ranges from $60-72$ per cent of the helght of the shaft just distal to the external cotyla, with much overlap of ranges between genera. Th1s rat10 is 83 per cent in Dendrortyx and 85 per cent in Phllortyx.

The distal radial impression is obsolete in most genera, well excavated in Denarortyx, and varlable in Odontophorus.

The notch between the carpal tuberosity and internal condyle 1s well developed in most forms, but it is obsolete 1n Dendrortyx.

The external condyle 18 well produced in Phllortyx. Cal11pepla, Col1nus, Lophortyx, and Odontophorus, moderately produced in Oreortyx, Cyrtonyx, and Dactylortyx, and weakly produced in Dendrortyx and Ihynchortyx. The external condyle arises abruptly from the shaft 1n wost forms, usually ar1ses abruptly from the shaft in Cyrtonyx, but arises gently from the shaft in Oreortyz, Lophortyx, and Rhynchortyx. The external condyle is rounded throughout in most genera, usually rounded in Cyrtonyz and Dactylortyx, but has 1 ts ventral border flattened in Dendrortyx and 
Ph1lortyx.

Carpometacarous.--Metacarpal I 18 moderately polnted terminaliy in Dendrortyx, Ph1lortyx, Callipepla, Odontophorus, and Bhynchortyx, usually moderately polnted terminally in Cyrtonyx, sharply polnted terminally in Oreortyx, usually rounded terminally in Dectylortyx, and variable in Colinus and Lophortyx.

The ridge that separates the anterior carpal fossa from the excavated area above the p1siform process is produced and extends well onto the base of the metacarpal I 1n most New World qua1l, but 1 t 18 very weak and extends only slightly onto the base of the metacarpal I in Dendrortyx.

The plsiform process is ovaloid in internal view in Oreortyx, Lophortyx, Dactylortyx, and Odontophorus, ellipt1cal in Bhynchortyx, round in Dendrortyx and Philortyx, and variable in callipepla, Collnus, and cyrtonyx. The pisiform process is slightly reflected dorsad and thus is below the level of the dorsal rim of the inner carpal trochlea in Oreortyz, Bhynchortyx, Dactylortyx, and Odontophorus, slightly reflected dorsad and usually below, but occasionally at the level of the Inner carpal trochlea in Call1pepla, Col1nus, and Cyrtonyx, moderately reflected dorsad and thus produced slightiy aboze the dorsal rim of the inner carpal trochlea in Phllortyx, wuch reflected dorsad and produced, well above the dorsal rim of the inner 
carpal trochlea in Denarortyx, and variable in Lophortyx.

The 11 gamental attachment of the p1siform process is produced and wuch swollen proximally and flattened distally in most New World quail. Odontophorus differs in that the IIgamental attachment is moderately or much swollen proximally, Cyrtonyx in that it is moderately swollen proximally, and Bhynchortyx in that it is weakly produced and only slightly swollen proximally, and Dendrortyx in that the 11 gamental attachment of the p1siform process is produced throughout and moderately swollen proximally and distally. The proximal portion of the ligamental attachment of the pisiform process is connected to the p1siform process by a bony bridge in most genera; the attachment 1s usually connected by a bony briage in Colinus, separated from the plsiform process by a shallow sulcus in Dendrortyx, and variable in Odontophorus.

The proximal border of the internal carpal trochlea is shallowly concave in Dendrortyx. Phllortyx, Phynchortyx, Cyrtonyx, and Dactylortyx, distinctly concave in Oreortyx, uśually slightly notched in Lophortyx and Odontophorus, deeply notched in Callipepla, and variable in Colinus. The ventral border of the internal carpal trochlea 1 w without a notch in most genera, but 1 t has a slight notch in Dendrortyx and Oreortyx.

The intermetacarpal tubercle extends to or slightly beyond metacarpal III w1thout ankylosis w1th 1t in most New 
World qua1l, it extends to and somet1mes ankyloses with metacarpal III in Lophortyx, extends to and ankyloses with metacarpal III in Dendrortyx, and does not reach or barely extends to metacarpal III in Cyrtonyx. The 1ntermetacarpal tubercle is relatively distally placed and has a small space between 1ts posterior border and junction of metacarpals II and III in most genera, but 1t is more proximally placed. and w1th oniy a elaute space between 1 ts posterior border and Junction of metacarpals II and III in Dactylortyx.

The tubercle on the internal proximal surface of the metacarpal III is obsolete in most forms, but it is elongate and weakly produced in Philortyx, and elongate and moderately produced in Oreortyx, Cyrtonyx, and Bhynchortyx.

The exterial proximal face of metacarpal III has a single strongly developed tubercle in oreortyx, Cal11pepla, Collnus, Lophortyx, and Odontophorus, a single moderately developed tubercle in Philortyx and Dactylortyx, a single obsolete to weakly developed tubercle in Cyrtonyx, a single obsolete tubercle in Bhynchortyx, and one moderately developed and one obsolete tubercle in Dendrortyx.

Metacarpal III is slightly bowed in most New World quall but $1 \mathrm{~B}$ moderately bowed in Dendrortyx.

Pelv1s.--The pelv1s of Dendrortyx, Ph1lortyx, and Colinus 1s relatively narrow, and the ratio of the wlath of the pelvis through the antitrochanters divided by the length of the innominate from the anterior edge of the 
111um to the 1 schial angle ranges from $44-51$ per cent. The pelvis of Oreortyx, Callipepla, and Bhynchortyx 18 relat1vely wide, the ratio belng 59 per cent in Bhynchortyx, $58-62$ per cent in Callipepla, and 60-63 per cent in oreortyx. The remalning genera are poorly separable on this character.

The pectineal process is moderately produced beyond the acetabular border w1th 1 ts apex pointed in Philortyx, Oreortyx, Callipepla, and Lophortyx, usually polnted in Col1nus, but rounded in Dendrortyx. The pectineal process is only slightly produced beyond the acetabular border as a minute point in Odontophorus, Cyrtonyx, and Bhynchortyx, and in Dactylortyx it is usually absent or at most, represented by a winute polnt.

The depression on the medial side of the pectineal process is deeply excavated and perforated by a foramen in Dendrortyx, deeply éxcavated and without a foramen in Philortyx, and shallowly excavated and w1 thout a foramen in Oreortyx, Callipepla, Colinus, and Lophortyx. The depressIon on the medial side of the pectineal process is obsolete and without a foramen in odontophorus, cyrtonyx, and Bhynchortyx, and absent in Dactylortyx.

The posterior 111ac crest lacks a prominence in most genera. A prominence is produced from the posterior 1liac crest just posterior to the 1110-1schlac fenestra in Dactylortyx and Rhynchortyx. The prominence is weak in 
Bhynchortyx, moderately produced in Daotylortyx, and strongly produced in Cyrtonyz.

A ridge originates on the posterior 11100 crest at the level of the 1110-1schlac fenestra, continues ventrad and posteriad towaras the posterior border of the 111um, and has a prominence arising from 1 t $B$ posterior portion in most New World quall. The prominence arlses sharply in Dendrortyx, Plillortyx, Lophortyx, and Colinus, but it is weak in Oreortyz and Callipepla. The ridge and prominence are absent in Dactylortyx, Cyrtonyx, and Bhynchortyx. odontophorus is varlable in this character.

The dorsal face of the post-acetabular 111 um 1 s moderately broad anterlad and narrows abmuptly posteriad to form the acute apex of the short, broad, dorsal roof of the posterior process in Dendrortyx, Philortyx, Call1pepla, Col1nus, and Lophortyx. It $1 \mathrm{~s}$ much broadened anteriad, and narrows abruptly posteriad to form the acute apex of the very short broed dorsal roof of the posterior process in Oreortyx. In Dactylortyx and Bhynchortyx the dorsal face of the post-acetabular 111uv is moderately broadened anteriad and narrows abruptiy posteriad to form the truncated apex of the moderately long, narrow, dorsal roof of the posterior process. Cyrtonyx has the dorsal face of the post-acetabular '1l1um narrow anter1ad, and 1t gradually furtber nerrows posterlad to form the polnted apex of the much elongated, narrow, dorsal roof of the posterior process. Odontophorus 
is variable in this character.

The caudal face of the post_acetabular llium is enlarged, triangular, and vertical in position, and its posterodorsal apex forms the posteromedial wall of the posterior process in Dendrortyx, Phllortyx, Call1pepla, Collaus, and Lophortyx. Oreortyx differs only in that the caudal face is broadly triangular. The caudal face of the post-acetabular 1lium is obsolete, horizontal in position, and forms the ventral floor of the posterior process in Odontophorus, Dectylortyx, Cyrtonyx, and Bhynchortyx. It is rectangular in shape in Dactylortyx and Bhynchortyx, triangular in odontophorus, and narrowly triangular in Cyrtonyx.

The lateral face of the post-acetabular 111 um has an acute posterodorsal apex in most New World qua1l, but it 18 much pointed in Cyrtonyx, and truncated in Bhynchortyx. It forms the shortened lateral wall of the posterlor process In most genera, but is moderately elongate in Rhynchortyx, elongate in Dactylortyx, moderately to much elongated in Odontophorus, and much elongated in Cyrtonyx.

The renal bar 1s very slender, and both the bar and the posterior process are excavated by the renal depression in Dendrortyx, Call1pepla, Col1nus, and Lophortyx. It is moderately slender in Philortyx, and obsolete in Oreortyx, and both the renal bar and posterlor process are excavated by the renal depression in these genera. The renal bar 1s 
broad and the bar, but the posterior process is not excavated by the renal depression in Odontophorus, Dactylortyx, Cyrtonyz, and Bhynchortyx. The bar is only slightly excavated in Bhynchortyx.

The 1schlum lies at an agle of about 160 degrees to the venti-al edge of the posterlor 111 ac crest in most New World qua11, but 1t lies at an angle of about 145 degrees to the ventral edge of the posterior $111 \mathrm{ac}$ crest in Cyrtonyx.

The synsacrum of Dendrortyx 18 long and narrow, with a 55 per cent ratio of the width through the transverse processes of the fourth syngacral vertebra alvided by the length of the synsacrum from the centrum of the first synsacral vertebra through the transverse process of the fourth synsacral vertebra is 55 per cent. The synsacra of Bhynchortyx and Dactylortyx are much shorter and w1der, w1th the rat10 88-93 per cent in Dactylortyx, and 92 per cent in Fhynchortyx. The other genera have the syasacrum shorter and w1der than Dendrortyx, and longer and narrower than Phynchortyx and Dectylortyx, but are poorly separable among themselves.

Femur.--The head 18 moderately enlarged in most forms, but it is wuch enlarged in Dactylortyx and is variable in Lophortyx. The head is ne1ther bent dorsally nor rotated posteriorly in most genera, but it is bent dorsally and w1thout posterior rotation in Rhynchortyx, and bent dorsaliy and rotated posterlorly in Dendrortyx. 
The neck 18 only moderately long in most New World qua11, but it is long in Dendrortyx, and short in Cyrtonyx.

The 111ac facet is without compression, and 1ts dorsal border is flat in most genera, but it is compressed with 1 ts poster1or border stra1ght in Dendrortyx.

The aorsal crest of the trochanter is compressed and reflected with 1ts dorsal border rounded in Philortyx, Oreortyx, Call1pepla, Dactylortyx, usualiy compressed and reflected with the dorsal border rounded in Lophortyx, depressed and deflected w1th 1ts dorsal border flat in Dendrortyx, Odontophorus, and, Cyrtonyx, obsolete and flattened in Rhynchortyx, and variable in Colinus.

The trochanteric ridge is about 20-25 per cent of the length of the femur in most New World quall, but the rat1o is only 12 per cent in Rhynchortyx.

The distal depth 18 about 80-90 per cent of the d1stal width in most genera, but the ratio is 71 per cent in Rhynchortyx, and 97 per cent in Philortyx.

The internal condyle is moderately wide and has 1 ts anterlor border much produced throughout in most forms. Cyrtonyz differs only in that the anterior border of the Internal condyle is weakly produced throughout. Dectylortyx differs in that the internal condyle is narrow and usually has 1 ts anterlor border weakly produced throughout, whereas 1n Philortys the anterlor border of the internal condyle is very wide, and 1ts anterior border is moderately produced 
throughout.

The external condyle is compressed and rounded anteriorIy in most New World qua1l, but it $1 \mathrm{~s}$ depressed and flattened anteriorly in Dendrortyx.

Tiblotarsus.-.-The depth of the inner cnemial crest is well over 50 per cent of 1 ts length in most New World quall, but the ratio 18 $42-48$ per cent in Dectylortyx, 45 per cent in Ph1lortyx, and 37-46 per cent in Cyrtonyx.

The outer cnemial crest is stralght in Oreortyx, Odontophorus, and Dactylortyz, usually straight in Call1pepla, Col1nus, and Cyrtonyx, decurved in Dendrortyx, Ph1lortyx, and Bhynchortyz, and var1able in Lophortyx.

The interarticular tubercle 18 weakly produced in Ph1lortyx, Dectylortyx, Cyrtonyx, moderately produced in Dendrortyx, Call1pepla, Lophortyx, and Rhynchortyx, usually moderately produced in Colinus, moderately or strongly produced in Odontophorus, and strongly produced in Oreortyx.

The area between the external articular surface and outer cnemial crest 18 moderately concave in dorsal view in most New World quall, moderately or deeply concave in Odontophorus, and very deeply concave in Dactylortyx.

The posterior margin between the external and internal articular surface has a distinct notch in most genera, but 1t 18 weakly notched in Dendrortyx.

In most New World quall the area just anterior to the ridge for the proximal interal 11gamental attachment lacks 
the deeply excavated depression present in Dendrortyx.

The area of the 1nternal 11gamental attachment on the Internal condyle is moderately produced as a prominence in most New World qua1l, strongly produced 1n Dendrortyx, and without a prominence in Dectylortyx and Bhynchortyx.

The face of the interual condyle 18 moderately excavated w1th 1 ts border moderately elevated 1n most genera, but 1t is well excavated with its border highly elevated in Dendrortyx, and: weakly excavated with slightly elevated border in Rhynchortyx.

The dorsal border of the supratendinal bridge is stra1ght in Philortyx, Cal11peola, Dactylortyx, and Cyriony2, usually straight in Oreortyx, Lophortyx, and Odontophorus, oblique in Dendrortyx and Rhynchortyx, and variable in colinus.

Tarsometatarsus.--The 1ntercotylar prominence is moderately deflected In'most New World qua1l, but it is much deflected in Philortyx, only slightly deflected in Dectylortyx, and depressed and w1thout derlection in Bhynchortyx. The apex of the intercotylar prominence 1s 'pointed in Dendrortyx, Phllortyx, Lophortyx, Odontophorus, and Cyrtonyx, usually polnted in Oreortyx, Callipepla, Colinus, and Dectylortyx, and broadly rounded in Rhynchortyx.

The posterior intercotylar area is moderately excavated as a triangular depression in Dendrortyx, Odontophorus, 
and Dactylortyx, usually moderately excavated as a triangular depression in Cyrtonyz, weakly excavated as a triangular depression in Ph1lortyz, Collnus, and Call1pepla, usually weakly excevated as a triangular depression in Lophortyx, unexcavated in Bhynchortyx, and usually unexcavated in Oreortyx.

The area surrounding the posterlor opening of the 1nner proximal foramen is shallowly excavated 1n Oreortyx, Call1pepla, Col1nus, Lophortyx, and phynchortyx, moderately excavated in Dactylortyx and Cyrtonyx, deeply excavated in Dendrortyx and Philortyx, and very deeply excavated in Odontophorus.

The hypotarsus has two well developed and one obsolete calcaneal ridges in most genera, but there are two well dereloped and one weakly developed calcaneal ridges in Dactylortyx, and three well developed calcaneal ridges in Bhynchortyx. The hypotarsus has two closed calcaneal eanals in most New World qua11, but there 1s only one closed calceneal canal in Dendrortyx and Bhynchortyx, usually one in Oreortyx, and the condition is varlable in odontophorus.

The anterior face of the shart 18 extensively excavated by the anterior metatarsal groove in Dendrortyx, Phllortyx, and Bhynchortyx, moderately excavated by the anterior metatarsal groove in Callipepla, usually moderately excavated by the anterior metatarsal groove in 
Collnus and Cyrtonyx, usually reduced in Lophortyx, reduced In Odontophorus, reduced or obsolete in Dactylortyx, and reduced or absent in Oreortyx.

The trochlea for diglt II 1s only slightly inflected in most New World quall but 1s moderately inflected in Oreortyx, Dectylortyx, and Cyrtonyx.

The wing of the troohlea for diftt IV 1s depressed. dorsoventrally with the ent1re trochlea much deeper than long in most reners, but in Dendrortyx and Odontophorus the wing is depressed anteroposterlorly, and the entire trochlea 1s longer than deep.

Intermembral proportions.-.The ratio of the comblned length of the bones of the w1ng (humerus, ulna, carpometacarpus) divided by the combined length of the bones of the leg (femur, tiblotarsus, tarsometatarsus) divides the New World quall 1nto three groups. Dendrortyx has a relatively shert wing w1th ratio of 52 per cent. Cyrtoryx and Dectylortyx have relatively long wings as th1s rat10 is 78-81 per cent in Cyrtonyx and 72-73 per cent in Dactylortyx. The other forms are intermediate; the ratio ranges from 60-69 per cent, w1th considerable overlap between genera.

The ulna 18 more than 95 per cent of the length of the humerus in Odontophorus, Dactylortyx, and Bhynchortyx. The other forms range from $86-94$ per cent in this rat10, w1th much overlap between genera. 
The tarsometatersus is more than 85 per cent of the length of the femur in Dendrortyx and Rhynchortyx, and. $84-87$ per cent in Odontophorus. The other forms range from $70-83$ per cent in this rat10, with much overlap between genera.

The tarsometatarsus is 63 per cent or more the length of the tiblotarsus in Dendrortyx, Odontophorus, and Bhynchortyx. The other forms range from 53-61 per cent in this rat10, with considerable overlap between genera.

The humerus is 71 per cent of the length of the femur in Dendrortyx, but 90.91 per cent in Dactylortyx, and 95-100 per cent in Cyrtonyx. The other forms are indeterm1nate, and this ratio ranges from 80.88 per cent, w1th considerable overlap between genera.

The humerus is 51 per cent of the length of the tiblotarsus in Dendrortyx, and 72-75 per cent in Cyrtonyx. The other New World quall are Intermediate, and this ranges from 58-67 per cent, w1th much overlap between genera. The ulna $1 \mathrm{~s} 63$ per cent of the length of the femur in Dendrortyx, 87 per cent in Rhynchortyx, 88-91 per cent in Dactylortyx, and 89-93 per cent in Cystonyx. The other forms are 1ntermediate, and the rat10 ranges from 68.85 per cent, w1th cons1derable overlap between genera.

The ulna 1s 45 per cent of the length of the t1blotarsus in Dendrortyx, 65-66 per cent in Dectylortyx, and 68-71 per cent in Cyrtonyx. The other New World quall are 
1nterwed1ate, and the rat10 ranges from 50-62 per cent, w1th much overlap between genera.

The uina 1s 72 per cent of the length of the tarsometatarsus in Dendrortyx and 126-133 per cent in Cyrtonyx. The other New World quall are 1ntermediate, and this ratio ranges from 87-111 per cent, with cons1derable overlap between genera.

The carpometacarpus is 27 per ceat of the length of the tiblotarsus in Dendrortyx, and 38-40 per cent in Cyrtonyz. The other forms are 1 ntermediate, and this ratio ranges from $31-36$ per cent, w1th much overlap among genera. The carpometacarpus 1s 42 per seat of the length of the tarsometatarsus in Dendrortyx, and 71-74 per cent in Cyrtonyx. The other forms are 1utermediate, and the ratio ranges frow $54-66$ per cent, w1th much overlap between genera.

The tersonetatarsus 18124 per eent of the length of the humerus in Dencirortyx, but only 70.74 per cent in Cyrtonyx. The other New World quall are 1ntermediate and this rat1o ranges from $85-101$ per cent, w1th constderatle overlap between genera.

The 111um is 89 per cent of the length of the sternum in Dendrortyx, whereas this ratio ranges from $65-78$ per cent in the other forms, with much overlap between genera. The helght of the sternal carina 18 34 per cent of the length of the 1lium in Dendrortyx, and 52 per cent in Bhynchortyx. The other forms are interwediate, and this 
rat10 ranges from $37-49$ per cent, w1th much overlap between genera.

$$
\text { Major Relationsh1ps }
$$

The New World quall may be divided Into two distinct groups on the basis of striking differences in pelvic structure. One group w11l herein be referred to as the Dendrortyx group, and as having the Dendrortyx type of pel$\nabla 18$, whereas the other group w11l be referred to as the Odontophorus group, and as having the Odontophorus type of pelvis. The following genera are included in the two Grous: :

Dendrortyx group

Dendrortyx

Phllortyz

Oreortyx

Cal11pepla

Col1nus

Lophortyx
Odontophorus group

Odontophorus

Dactylortyx

Cyrtonyx

Bhynchortyx

Differences in the two basic pelvic types are outlined below. (I) In the Dendrortyx type the pectineal process 18 moderately produced beyond the acetabular border. In the Odontophorus type the pectineal process is represented only by a minute point or 18 absent. (2) In the Denarortyx type the depression on the medial side of the pectineal process 1s distinct. In the odontophorus type the depression is obsolete or absent. (3) In the Dendrortyx type the posterior $111 a c$ crest $1 \mathrm{~s}$ without a prominence. In the 
Odontophorus type a prominence is usually produced from the posterior $111 a c$ crest. (4) In the Dendrortyx type a ridge originates on the posterior $1110 \mathrm{c}$ crest at the level of the 1110-1schlac fenestra, cont1nues ventrad and posterlad towards the posterior border of the 111um, and has a prom1nence that arises from 1ts posterior portion. In the Odontophorus type the rldge and prominence are absent, except in one specimen of Odontophorus gujanens1s. (5) In the Dendrortyx type the dorsal face of the post_acetabular 111um 1s relatively short and broad. In the Odontophorus type the dorsal iace of the post_acetabular 111 um is rela. truly long and narrow. (6) In the Dendrortyx type the caudal face of the post-acetabular 111 um is enlarged, triangular, vertical in position, and 1ts posterodorsal apex forms the posteromedial wall of the posterior process. In the Odontophorus type the caudal face of the post-aceiabular 1llum is obsolete, variable in shape, horizontal in position, and forms the ventral floor of the posterior process. (7) In the Dendrortyx type the lateral face of the post-acetabular 111 um is relatively short. In the Odontophorus type the lateral face of the post-acetabular 111 um is relatively long. (8) In the Dendrortyx type the renal bar 18 very poorly developed or obsolete, always slender, and both the bar and the posterior process are excavated by the renal depression. In the odontophorus type the renal bar is well developed and broad, and the bar, but 
not the posterior process, is excavated by the renal depression.

\section{The Dendrortyx Group}

The major skeletal modifications and possible affinities of the genera in the Dendrortyx group are discussed in the following paragraphs.

Dendrortyx.--Th1s genus appears to be the most prim1tive, as well as the most aberrant genus of the New World qua11.

Numerous characters of Dendrortyx are suggest1ve of those in less advanced gallinaceous familles. (1) The dorsal intermuscular line of the coracold 1s sherply ralsed only along 1 ts distal f1fth. (2) The ventrel intermuscular ine of the coracold terminates in the miale of the alstal border of the sterno-coracoldal process. (3) The doral face of the coracold has a round, deep fossa, below the tubercle for the 11 gamentum sterno-coracoldeum dorsale, and above, the external end of the sternal facet. This is probably a remnant of the deep pneumatic fossa found in th1s position in several less advanced familles. (4) The tip of the sterno-coracolal process of the corrcold is w1.thout a terminal knob. (5) The depression on the medial side of the pectineal process of the pelvis is perforated by is foramen. (6) The fosse II of the humerus is lndistinct. (7) The hypotarsus has only one closed calcaneal 
canal.

At the same time Dendrortyx is the most aberrant genus of New World quall, since it has 30 unlque characters excluding intermembral proportions, and 41 unlque characters including these proportions. The distinctive intermembral proportions in Dendrortyx reflect the fact that the leg bones are very long in comparison with the wing bones, the 111um very long in comparison with the steraum, and the height of the stemal carina low in comparison with the length of the 111um. - Dendrortyx has the largest measurements in the Denarortyx group.

Philortyx.--Philortyx 1s possibly the closest I1ving relative of Dendrortyx, with which it shares the four following skeletal characters. (1) The capltal groove of the humerus 1s deeply excavated and has 1 ts 1nternal margin strongly elevated. (2) The helght of the middle of tile shaft of the ulna is about 85 per cent of the helght of the shaft just alstal to the external cotjia. (3) The pisiform process of the carpometacarpus is round in internal view. (4) The external condyle of the ulna has 1 ts ventral border flattened. Phllortyx has elght unlque characters, but aside from 1ts small s1ze, 1t does not show strik1ng skeletal modifications.

Creortyx.-.-This genus appears to show more relationshipa to Colinus, Lophortyx, and especially to Call1pepla (on characters on the scapula, and in pelvic proportions), 
than 1 d does to Dendrortyx and Philortyx. Oreortyx has $s 1 x$ unlque characters, but other than its relatively large size measurements, it shows no particularly noteworthy skeletal modifications.

Cal110epla, Col1nus, and Lophortyx..-In many cases the genera of this complex cannot be separated on the basis of Individual bones, and there is not a single unique generic character. In short Call1pepla, Collnus, and Lophortyx are so similar in skeletal structure that it would be very terpting to include ther in a single geaus were it not for the fact that the specles fall lato three separate groups on external morphology. It appears that Callipepla, Col1nus, and Lophortyx have alverged relatively recently, and subgener1c rather than generic designations wight better reflect their texonomic status.

other studies support this view. Balley (1928) reports a hybrid Cal11pepla squamata $x$ Lophortyx gambel11. S1bley (1960) states that species of Collnus, Lophortyx, and Callipepla hybridize 1n various comblnations. S1bley (op. clt.) also reports that Call1pepla, Collnus, and Lophortyx share a characterist1c egg-white prote10 proflle, different frow that of Oreortyx.

\section{The Odontophorus Group}

The major skeletal modifications and possible affinities of the genera of the Odontophorus group are discussed 
1n the following paragraphs.

Odontophorus.--Th1s genus appears to be the most primitive of the Odontophorus group. Several 1mportant characters of odontophorus are found in less adranced gallinaceous fam111es. (1) The preumat1c fossa of the humerus has a perforated Inner shelf that extends from the external biclpital surface to the medial bar in odontophorus gujanens1s. (2) The fossa II of the humerus is indistinct. (3) The hypotarsus has only one closed calcaneal canal in Odontophorus stellatus.

The large size of Odontophorus in comparison with those of other New World quall possibly indicates a primitive trait in this genus, for there seems to be a progressive trend towards decrease in slze of the more advanced Galli. The trend is summarized as follows:

$$
\text { General S1ze of Gall1 }
$$

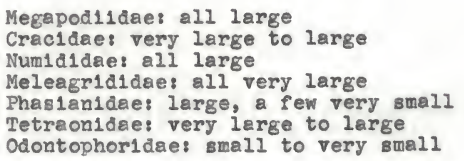

Some very noteworthy characters occur on the pelvis of certaln specimens of odontophorus. (1) The posterior 1liac crest of the pelvis has a prominence in all odontophorus studied, w1th the exception of one individual of Odontophorus gujanensis. (2) A ridge originates on the posterior $111 a c$ crest at the level of the $1110-18 \mathrm{ch} 1 \mathrm{ac}$ fenestra, 
continues ventrad and posteriad towards the posterior border of the 111um, and has a prominence that arlses from 1ts posterior surface in one individual of Odontophorus gujanens1s.

These characters have 1nteresting 1mplications, for they are associated with the Dendrortyx type of pelvis and are not found in any other genus in the Odontophorus group. Dendrortyx certalnly appears to be the most primitive genus of New World qua1l, and thus 1t would seem probable that the Dendrortyx type of pelvis was evolved earlier than the Odontophorus type. Therefore the occaslonal occurrence of these characters in a primitive geaus of the odontophorus group is not surprising.

Further substantiating the primitive nature of Odontophorus is the fact that it shares three characters w1th Dendrortyx only, namely: (1) large size; (2) an 1nd1stinct fossa II of the humerus; (3) the wing of the trochlea for diglt IV depressed anteroposteriorly and the entire trochlea is longer than deep.

Odontophorus is a rather generalized form, w1th much specific variation and with only two unique characters. Dactylortyx.--This genus has 10 unique characters but still does not show as many skeletal modifications as the following two genera. Perhaps the most 1mportant skeletal modifications in Dactylortyx are the tendency towards the 
loss of the pectineal process, w1th the complete loss of the depression on the medial side of the pectineal process, and the elongation of the bones of the wing in comparison with the bones of the leg. Dactylortyx is relatively large. It appears to be more closely related to Cyrtonyx, somewhat more distantly related to Phynchortyr, and most distantly related to odontophorus on the basis of several quall tat1ve characters, as well as on intermembral proportions.

Cyrtonyx.-.Th1s form has 15 unique characters. Important skeletal modifications lnclude the very strong deflection of the acromion process of the scapula, the weak development of the intermetacarpal tubercle of the carpometacarpus, the narrow angle of the 1schlum to the ventral edge of the posterior 111 ac crest, and as in Dactylortyx the elongation of the bones of the wing in comparison to the bones of the leg. Cyrtonyx also has relatively large slze measurements. It appears most closely related to Dactylortyx, somewhat more d1stantly related to Rhynchortyx, and most distantly related to odontophorus, on the basis of several qualitative characters as well as on intermembral proportions.

Bhynchortyx.--This is the most aberrant genus of the Odontophorus group, as 1 t has 25 unlque characters. Important skeletal modifications include the short, deep, rostrum and the development of a third alstinct calcaneal 
ridge on the hypotarsus. Bhynchortyx has the smallest measurements of any genus in the odontophorus group. In several qualitative characters, as well as on latermembral proportlons, Bhynchortyz appears more closely related to Cyrtonyz and Dactylortyx than to Odontophorus.

\section{Remarks}

In summary Dendrortyx appears to be at once the most primitive and aberrant genus of the New World quall. Philortyx 1s possibly 1ts closest relative. Oreortyx is closely related to Collnus, Lophortyx, and especially to Callipepla. Call1pepla, Col1nus, and Lophortyx are so similar that on osteological grounds they might best be merged in a single genus.

Odontophorus appears to be the most primitive genus in the Odontophorus group. Dectylortyx and Cyrtonyx show several similarities and appear closer to Rhynchortyx than to Odontophorus. Bhynchortyx is the most aberrant genus of the Odontophorus group.

On the basis of the present study, the following rearrangement 18 proposed: 
Sequence of genera

1n Peters (1934)

Dendrortyx

Oreortyx

Callipepla

Lophortyx

Phllortyx

Col1nus

odontophorus

Dectylortyx

Cyrtonyz

Bhynchortyz
Proposed sequence

of genera

Group 1

Dendrortyx

Ph1lortyx

Oreortyx

Callipepla

collnus

Lophortyx

Group 2

Odontophorus

Dactylortyx

Cyrtonyx

Bhynchortyx 
FOSSIL RECORD OF NEW WORLD QUAIL

Amerlcan quall are reported from 011gocene to Becent t1mes, but the single 011gocene form is Indeterminate at the generic and speciflo levels. Modern genera are flrst recorded from the Mlocene serles, and modern specles flrst appear in the Plelstocene.

\section{Tertiary Forms \\ Odontophor1dae, Indeterminate}

Hor1zon and local1ty.--O11gocenes 811 ts of Orellan age in the Cedar Creek facles of the White BIver formation. From SW 2/4 sec. 12, T. 11. N., R 54 W., Logan County, Colorado (Tordof, 1951b).

Mater1al...-D1stal end of a tarsometatarsus (University of Kansas Natural H1story Museum).

Bemarks.--Tordorf states that the 011gocene fossil 18 smaller than Collnus and Lophortyx, but it most elosely resembles these genera. It 18 very diffoult to differentlate some Amerlcan genera of quall (or even some gallinaceous families) on the distal portion of the tarsometatarsus, and the reported affinitles of the 011gocene fragment should be regarded w1th some caution. 
M1ortyx A. H. M11ler 2944

The genus 18 known from a single species recorded from the Lower Mlocene of South Dakota.

$$
\text { Miortyx teres A. H. Miller } 1944
$$

Horlzon and local1ty.--Lower Mlocene: late Arlkareean stage of Rosebud formation. Frow Flint H1ll quarry, Bennett County, South Dakota (A. H. Miller, 1944).

Material.--Type, proxlmal three-fourthe of right humerus, University of Callfornla Museum of Paleontology no. 34453. Referred specimen, distal end of left t1blotarsus.

D1agnos18..-" Iroximal end of humerus similar to that of Oreortyx but decldedly larger; capltal groove sharply defined and narrower, especially at margin of head; contour of head more smoothly rounded, less Indented by capltal groove; 11gamental furrow on palmar surface deeper tubercle on middle of deltold crest proportionately larger."

Measurements.--"Type, greatest wiath of head of humerus perpendicular to axis of upper part of shaft, $12.9 \mathrm{~mm} .3$. least width of shaft, in medlolateral direction, 5.0." Bemarks.--A. H. Miller (1944) polnts out: "The most distinctive feature of Mlortyx is the rounded contour of the head with consequent shallow depression between the articular surface of the head and the internal tuberosity. Dendroriyx of Central Amer1ca approaches, but by no means

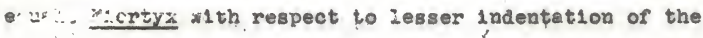


head contour by the capltal groove."

In the 11ving Odontophoridae fossa II of the humerus 1s usually well developed. Dendrortyz and Odontophorus are apparently less spectalized exceptions in which fossa II is obsolete. The drawing of the type specimen of Miortyx teres (A. H. M11ler, 1944, D. 94, f1g. 7) Indicates that fossa II, though not obsolete, 1s rather weakly developed.

Cyrtonyx Gould 2844

The genus 18 reported from the upper Nilocene of Callfornla and Nebraska, and from the Plelstocene of Aramberr., Nuevo Leon, Mexico.

Cyrtonyx cooks Wetmore 1934.

Hor1zon and local1ty.--Upper Mlocene: upper Sheep Creek beds. From if miles south of Agate, Sioux County, Nebraska (Wetmore, 1934).

Materlal.-.Type, alstal half of left humerus, collection of Harold J. Cook, no. H. C. 647 .

D1agnos1s..-"D1stal end of humerus s1m1lar to that of Cyrtonyz montezumae mearns 1 Nelson, but about one-fourth larger; ecteplcondyle relatively reduced."

Measurements.-.Greatest transverse breadth across condyles $9.5 \mathrm{~mm}$; least transverse breadth of shaft $4.6 \mathrm{~mm}$. Bemarks.--Wetmore (1934) reports that the foss12 is a northward extension of Cyrtonyx, whlch occurs today from central Arizona and central Texas southward Into Guatamala. 


\section{Cyrtonyx tedford1 L. M11ler 1952}

Horizon and locallty.--Upper Miocene: Barstow formation, Lake bed hor1zon. From near midale of SE 1/4, NW 1/4 sec. 15, T 11, N, B 2 W, near the town of Barstow, Cal1fornia (L., Miller, 1952).

Mater1al.--Type, right carpometacarpus, Un1versity of Cellforn1e. Museum of Paleontology no. 42223.

D1agnos18.--"Very similar to male of Cyrtonyx montezumae mearns1, but much stouter, and w1 th intermetacarpal tubercle much less developed."

Bemarks.--Th1s fOBs1I needs restudy. The photograph of the type carpometacarpus (L. Miller, 1952 p. 299, f1g. 2) shows the following characters: (1) plsiforw process reduced, and at the level of 1 ts 11 gawental attrchment. (2) Intermetacarpal tubercle obsolete, represented only by a minute point. (3) carpal trochlea with 1 ts external rim continuing alstad beyond 11gamental notch. These are strong characters of the family Cracidae and do not occur in any 1171 g genus of American qua11. It 18 thus possible that the above foss1l represents small specles of the Cracldae. Colinus Goldruss 1820

The genus is reported from the late Pllocene of Arizona and Kansas, the Plelstocene of Florida and Texas, and prehlstoric deposits from caves in Yucatan, Florida, Texas, and Teunessee. 
Colinus $\mathrm{sp}$.

Hor1zon and local1ty.--Upper P110cene. From sec. 22, T $17 \mathrm{~S}, \mathbb{2} 20 \mathrm{E}$, about two miles south of Benson, Arlzona (Wetmore, 1924).

Mater1al.-.D1stal port1on of tarsometatarsus (United States Nat1onal Museum).

Remarks.--The fossll has a smaller and narrower middle trochlea than Callipepla, and a lower distal foramen than elther Col1nus V1rE2nianus or Lophortyx gambel11 (Wetmore, 1924).

\section{Co11nus h1bbard1 wetmore 1944}

Hor1zon and Iocal1ty...Upper Pl1ocene: Bexroad formet_100. From Local1ty 3, Rexroad fauna, Meade County, Kansas (Wetmore, 1944).

Mater1al.--Type, distal portion of right tarsometatarsus, w1th wost of the outer trochlea m1ssing, University of Kansas Museum of Vertebrate Paleontology no. 3981. Referred specimens, distal end of rlght humerus and istel end of badly worn left humerus.

D1agnos1g.-." D1stal end of tarsometatarsus ( $11 \mathrm{~g} 8.4$ and 5) similar to that of wodern Colinus V1rgin1anus (Linnaeus) but decldedig larger; shaft stronger, and wore heavily lined by the tendinel grooves."

Measurements.--Type: "Transverse breadth of shaft below center, $3.1 \mathrm{~mm} . ;$ transverse breadth across trochlea (approx1_ mato), $7 \mathrm{~mm}$. 
Bemarks.--Wetmore (1944) reports that the type tarsometatarsus shows more angular development of the posterior side of the middle trochlea than in Lophortyx, stouter form throughout than in Callipepla, and larger trochleae than in Cyrtonyz. The referred humerus (University of Kansas Museum of Vertebrate Paleontology 3997) shows simllarit1es to Col1nus V1rglnlanus, but the brachlal depression is larger, and the ridge that borders it $1 \mathrm{~g}$. longer and extends farther up the shaft. In size it is similar to adult male Cyrtonyx montezumae mearns1, but the trochleae are definitely smaller. The radial trochlea is larger than in Callipepla. All of the above fossils are larger than Collnus v1rg1n18nus.

Tordoff (19.12a) reportis on 32 bones of Collnus hibbardi from the type locality. Fossil elements include five vertebrae, three sterna, seven coracolds, one humerus, I1ve ulnae, seven carpometacarp1, and four tarsometatars1. Tordoff P1nds that the rossils are similar to the bones of Recent collnus v1rginlanus but larger, and the w1ng bones are longer in relation to the leg bones. Subjective differences lnclude the following characters: (1) Ventral laterwuscular 11ne of coracold less promlnent and less sharply defined than in Becent C. v1rginlanus. (2) Shaft of humerus stralghter and heavier, and brachlal depression larger. (3) Impression of M. brachlal1s ant1cus on ulna deeper and more sharply out. 11ned. (4) Intercotylàr promlnence of tarsometatarsus more nearly round, depression just over posterlor edge of 1nternal 
cotyla more angular and sharply marked, and the ridge leading proximad from the outer proximal foramen wore sharply defined. Odontophoridae, Indeterminate

Horlzon and local1ty.-.Upper P110cene. From s60. 25, T 18 S, B 21 E, about 14 m12es southeast or Benson, Arizona (Wetmore, 1924).

Mater1al.-.Proxlmal end of a humerus (United States Nat1onal Museum).

Remarks.--Wetmore notes that this fragwent is large as In Oreortyx, but has characters $11 \mathrm{ke}$ Col1nus. It seems poss1ble that the specimen represents c. h1bbard1.

Lophortyx Bonaparte 1838

The genus 1s reported from the mldale Pllocene of Oregon, the Plelstocene of Califorala, and from archeological sites in California and Arizona.

Lophortyx shotwell1 Brodkorb 1958

Horlzon and locsilty.-.MIddle Plelstocene: Hemphllisan stage. From tuffaceous sandstone on the east bank of McKay Beservolr, about flve miles south of Pendleton, Umatilla County, Oregon (Brodkorb, 1958).

Mater1al.--Mype, proximal portion of left humerus, Un1versity of Oregon Museum of Natural H1story, no. F-3611. Beferred material, proximal portion of left humerus, and distal portion of two left humeri.

Bemarks.-.The type material was avallable for exam1nation during the present study through the k1 ndpess of Dr. 
Brodkorb and the Un1versity of Oregon Museum of Natural H1story.

A description based on this re-examination 18 as follows: Humerus with (1) Greatest proximal w1ath $9.8 \mathrm{~mm}$. 1n type speclmen (referred specimen broken). (2) Greatest d1stal w1dth $7.3-7.3 \mathrm{~mm} .(7.30 \mathrm{~mm} \cdot)$. (3) Paeunat1c fossa moderately elongate, elliptical, reduced in 1 ts distal extent, and with a restiglal, perforated, Inner shelf.

(4) Median orest strongly developed, elevated throughout.

(5) Capital groove moderately excavated with 1ta lnternal margin moderately elevated. (6) Margin between head and Internal tuberosity moderately concave. (?) Head about as long as broad in anconal view. (8) Bldge along medial border of rossa II moderately swollen, elongate, and with 1 ts apex acute. (9) Fossa II well developed. (10) Lat1ss1mus riage orlglnating on lateral edge of shaft, but sw1nglng 1 n onto anconal face proximally. (11) External tuberosity weakly 1nflated. (12) B1c1p1tal crest ar1sing gently from shaft, narrowly rounded, w1th 1 ts distal border lacking a groove. (13) Delto1d crest moderately developed, \$11ghtly laflected, and with 1ts summit flattened in type specimen (knob-like in referred specimen). (14) Enteplcondyle at level of internal condyle. (15) Enteplcondylar prominence moderately producel, with its pit placed on Internal face. (16) Depression of M. brachlalls antlous moderately excavated.

Several of the above characters are noteworthy. Per- 
haps most 1nteresting is the vestiglal, perforated, 1nner shelf of the pneumatio fossa of the humerus. An Imperforate, complete inner shelf 1s present in most other families of the Gall1, but has been lost in all living New World. qua11 w1th the exception of Odontophorus gujanensis, which retalas a perforated 1 nner shelf. Lophortyx shotwell1 differs from all Recent specles of Lophortyx in characters 3, 4, 11, and 14 above, and shares character 7 with Recent Denarortyx, Philortyx, and Lophortyx douglas11 only.

\section{Plelstocene Forms}

Denarortzz Gould 1844

The genus 1s reported from the Plelstocene of Nuevo Leon, Mexico, and tentatively from a prehistoric deposit in a Yucatan cave (F1Bher, 1953).

$$
\text { Dendrortyx (?) } \mathrm{sp} \text {. }
$$

Horlzon and local1ty.-..Plelstocene. Frow Sen Josec1to Cavern, province of Aramberrs, state of Nuevo Leon, Mexico (I. M11ler, 1943).

Materlal.--A single femur (University of Callfornia Museum of Vertebrate Paleoutology).

Bemarks.--L. H. M1ller reports that the above femur 18 larger and heavier than that of a Recent specimen of Dendrortyz leucophrys nlcaraguae, but the folsil is not Ident1ried to species. 
Oreortyx Ba1ra 1858

Reported from the late Plelstocene of Callfornia, and from the Quaternary (probably prehistoric) of a New Mexico cave.

\section{Oreortyx plote (Douglas) 1829}

Horlzon and local1ty.--(a) Late Plelstocene. From Potter Creek Cave, Shasta County, Callfornla (l. M1ller, 1911).

(b) Late Ple1stocene. From Samwel Cave, Shasta County, California (L. Miller, 1912).

(c) Late Plelstocene. From Hawver Cave, Eldorado County, Cal1fornia, (L. M11ler, 1911).

Material... (a) Potter Creek Cave; two bones. (b) Sam. wel Cave; not 11stea. (c) Hawrer Cave; 14 bones. Bones frow the anje localities are at the University of Cal1fornia Museum of Vertebrate Paleontology.

\section{Neortyx new genus}

Type of genus.--Neortyx pen1nsular1s new species. D1agnos1s.--D1ffers from I171ng genera of New World qua11 as follows. (1) Femur w1th proximal end narrow throughout, with head and trochanter small, but with shaft expanding abruptly into enlarged distal end (1n 11ving genera proximal end wider throughout, w1th head and trochanter larger, and with shaft expanding less abruptly into less enlarged distal end). (2) Anterior border of external condyle extending well onto distal portion of shaft as a 
strong ridge (anterior border of external condyle ending wore abruptly on distal portion of shaft as a weak ridge in I1VIng genera). (3) Internal 11p of external condyle reflected (derlected in I1ving genera). (4) Dorsolateral border of 111ac facet short (longer in 117ing genera). Closest to more speclallzed genera of the Dendrortyx group in having (1) heed nelther bent dorged nor rotated poster1ad, thus differing from Dendrortyx and Bhynchortyx. (2) Neck moderately long, thus differing from Dendrortyx. (3) Illac facet without compression, w1th posterior border convex, thus alffering from Dendrortyx. (4) Dorsal crest of trochanter broken. (5) Trochanterio ridge 24 per cent of length of shaft, thus differing from Bhynchortyx and Dactylortyx. (6) D1stal depth 83 per cent of distal w1dth, thus differing from Phllortyx and Rhynchortyx. (7) Internal condyle moderately w1de, and with 1 ts anterlor border much produced throughout, thus differlng from Philortyx, Cyrtony, and Dactylortyx. (8) External condyle compressed and rounded. anterlorly, thus differing from Dendrortyx.

Neortyx pen1nsular1s new species Holotype.--Left femur, complete exoept for broken dorsal crest of trochanter, PB 1224 (Brodkorb collect1on, Un1versity of Plorida). Plelstocene: Arredondo clay equivalent, in p1t of Dixle Ilme Products Company in the SW corner, NW $1 / 4 \mathrm{sec}$. 14, T 13 S, B 21 E, Mar1on County, Florida, one wlle southeast of the town of Beddick. Collected by Plerce Brodkorb 
August 9, 1954.

Measurements of holotype.--Length through art1cular Pacet, $45.8 \mathrm{~mm} .$, greatest proximal w1dth, $7.5 \mathrm{~mm} .$, distal width through condyles, $7.6 \mathrm{~mm}$., greatest proximal w1dth/ length 16.4 per cent, d18tal w1dth through condyles/greatest proximal width 101.3 per cent, proximal width of shaft/w1dth of shaft just proximad to 1nternal condyle 65.2 per cent.

D1agnos18.--Fenur larger than in Ph1lortyx Pasclatus, Oreortyx p1ota, Cal11pepla squamata, Collnus sull1um, $C$. V1rg1n1anus, C. n1grogular1s, C. Ieucopogon, Iophortyx cal1forn1ca, L. gambel11, I. douglas11, Dactylortyx thoracicus, and Cyrtonyx montezumee; smaller than in Dendrortyx leucophrys, Odontophorus gujanens1s, 0. stellatus, and 0. suttatus (Table 7 ).

Referred materlal.--The following elements frow the Ple1stocene of Reddick, Florida, are referred to the above species. One complete and two fragmentary right coracolds ( $P B$ 478, 1275, and 1974), and two fragmentary right ulnae (PB 935 and 1229).

Coracold: Internal distal angle short, rounded term1nally, and w1th 1 ts dorsal surface flattened (1nternal distal angle elongate, polnted termirally, and w1th 1 ts dorsal surface round in $11 \mathrm{ving}$ genera). Length, $29.0 \mathrm{~mm} .$, proximal w1ath $4.3 \mathrm{~mm} .$, distal w1ath (two specimens), 8.7-8.8 mm., distal w1dth/length 30.3 per cent, proximal width/a1stal w1dth 48.9 per cent, proximal w1dth/length 14.8 
per cent.

UIna: Olecranon process only moderately produced (strongly produced in most living genera, weakly produced in Bhynchortyx). Greatest proximal w1dth $6.0-6.3 \mathrm{~mm}$.

Femarks.--Th1s 18 the second extinct genus of New World qual1 described and brings the total of extinct and 11ving genera to 12 . The type specimen shows several resemblances to oreortyx, Ca111pepla, Col1nus, and Lophortyx, but 18 certainly quite distinct from these forms, as it has four characters unlque among New World qua1l. The referred elements Bhow two unlque characters, but otherwise are similar to birds in the Cal11pepla-Col1nus-Lophortyz complex in qual1 tat1ve characters, as well as in size.

\section{Collnus Goldruss 1820}

Col1nus sull1um Brodkorb 1959

Horizon and local1ty...-PIelstocene: Arredondo clay member of W1comico formation. From P1ts I and II in 11mestone quarry in $\mathrm{NW} 1 / 4 \mathrm{sec} .22, \mathrm{~T} 10 \mathrm{~S}, \mathrm{E} 9 \mathrm{E}$, near Arredondo, Alachua County, Florida (Brodkorb, 1959).

Mater1al.--Holotype, P1t I: complete left humerus, Brodkorb collect1on, no. 1291; paratype, complete right humerus, no. 757. Referred mater1al, P1t Is one sternum, two coracolds, four humerl, three ulnae, one carpometacarpus, one synsacrum, three tiblotarsi, three tarsometatarsi. P1t II: two coracolds, one scapula, one ulna, four humer1, two femora, three t1blotara1, and one tarsometatar\$us (Brodkorb 
collection, University of Florida).

D1agnos18:--For the orlg1nal description the reader 18 referred to Brodkorb (1959, p. 276).

Status of the Arredondo clay...-The Arredondo clay member of the WIcomico formation consists malnly of blue clay streaked with yellow, that weathers to brown. It was deposited under terrestrial conditions of sedimentation and contains fossils of Sresh-water gastropods and vertebrates. Arredondo clay 11 es beneath the W10omlco terrace, a reddish-brown marine aand. The exact age of the W1comlco formation is uncertaln at present, but it is possible that it represents elther Yarmouth or Sangamon Interglacial deposition (Brodkorb, personal communication). Therefore, the Arredondo clay may represent elther Kansan or I111nolan t1mes.

Other localit1es.--Fossil bones ass1gned to the species Colinus sull1um from other fossil locallties in Florida are 11sted in the next paragraphs, but they w111 be alscussed in a following sectlon on variation in fose1l Collnus.

(a) W111ston, Florida. Plelstocenes Arredondo clay. From slak-hole in Connell and Shultz Limerock Company mine, 0.9 miles north of Seaboard Alrline Ballroad, W1liston, Levy County, Flcrlala (Holman, 1959a sna 1959c). One rostrum, one coracold, I1ve humer1, one ulna, two carpometacarp1, four femora, three tiblotars1, and one tarsometatarsus (Brodkorb collection, University of Florida).

(b) Orange Lake, Florida. Ple1stocene; Arredondo clay 


\section{5}

and Arredondo clay-W1comico sand contact. From sink-hole in 11 mestone quarry near center of seo. 33, I 12 S, R 21 E, Marion County, Floride, two niles south of the town of Orange Lake (Holman, 1959b). Arredondo clays elght coracolds, four scapulse, vine humer1, two ulnae, one carpometacarpus, ten femora, five tiblotars1, five tarsometatarsi. Arredondo clay-W1com1co sand contacti one femur (Brodkorb collecticn, 'Un1versity of Florida).

(c) Redalck, Florida. Plelstocene: Arredondo olay equivalont. From localities A, B, C, and undesignated exact locallties (elther A or B) In pit of D1Xie Lime Products Company in the SW corner, NW $1 / 4$ sec. 14, T 13 S, R 21 E, Mex:. wa County, Florida, one alle southeast of the town of Reddick (Brodkorb, 1957).

Locality A: one sternum, flve coracolds, nine humer1, two ulnae, two femora, flve tiblotarsi, two tarsometatars1. Locality B: three coracolds, $81 x$ humeri, seven femora, two t1biotars1, seven tarsometatarsi. Locallty C: one rostrum, two coracolds, 15 humer1, four ulnae, nine carpometacarpl, one synsacrum, elght femora, four tiblotars1, four tarsometatars1. Local1ty $A$ or $B$ (undes1gnated): one rostrum, three sterna, 6ó coraco1ø̄s, n1ne scapulae, 138 humer1, 63 u.lnae, 30 carponetacarp1, f1ve syasacra, 90 femora, 77 t1b10tars1, 61 tarsometatars1 (Brodkorb oollect1on, Ualversity of Floride).

The total of 644 bones from Beddick represents a rela. 
tively tremendous number of Ind1vidual fossil bird bones. There are 74 left humer 1 from Reddick, so that a mlnimum number of 74 individuals is represented.

(d) Halle II, Florida. Ple1stocene: Arredondo clay. Frow locallty II B in NW 1/4, sec. 25, T $9 \mathrm{~S}, \mathrm{~B} 13 \mathrm{E}$, Alachua County, Florlda, near the viliage of Halle (Auffenberg, 1955). A gragmental ulna and t1blotarsus (collection of Howard flutchison at the UnIversity of Florlda).

(e) Oakhurst Quarry, Florida. Ple1stocene. From Oakhurst L1mestone Quarry, two miles southeast of Ocala Post orflce, Marlon County, Florida. A single left humerus (Brodkorb collection, UnIversity of Florla). As no extlnct vertebrates have been taken from this locality 1 ts age 18 uncertaln.

(f) Zuber, Florida. Plelstocene; Arredondo ciay equivalent. Dixle LIme Produots Company mine, Zuber, Marlon County, Florida. One femur (Brodkorb collection, University of Florida).

(g) Elchelberger Cave, Florlaa. Plelstocene (stratigraphy unclear). From Locality A in solution cave in NW corner of sec. 2, I 17 S, B $22 \mathrm{E}$, Marion County, Florida, two miles southwest of the town of Bellevlew (Brodkorb, 1956). One humerus, one femur, one t1blotarsus, and one tarsometatarsus (Brodkorb collection, University of Florida).

(h) Lake Monroe, Florlda. Ple1stocene. From Locality $N$, aredged from mouth of Lake Monroe, Volusia County, Florida. 
associated with extinct Plelstocene vertebrates.

Spec1mens frow looklities (d) through (h) are tentat1vely referred to $C$. sullium, as they show an approach to C. virginianus in some respects.

\section{Col1nus v1rgin1anus (Linnaeus) 1758}

Foss11 bones asalgned to the spec1es Col1nus V1rgin1anus are 11sted in the next paragraphs but w11l be discussed in the following section on variation in fossil colinus.

(a) Kanapaha, Flor1da. Plelstocene (strat1graphy.unclear). From 11mestone quarry in seo. 22 B $19 \mathrm{E}, \mathrm{T} 10 \mathrm{~S}$, Alachua County, Florlda, about 1.5 m1les SW of the v1llage of Arredondo (Brodkorb, 1958). Two humer1, one carpometacarpus, one remur, and one tiblotaraus (Brodkorb collectlon, Unlvers1ty of Florida). The bones are from tan sand in solution holes in the Ocala limestone, but the relationship of the deposit to the W1comlco terrace 18 not well marked.

(b) Saber-tooth Cave, Florida. Plelstocene: post. W1 comlco. From solution cave in NW 1/4, SW 1/4, sec. 33 T $18 \mathrm{~S}, \mathrm{~B} 18 \mathrm{E}$, C1trus County, Florida, 1.2 miles NW of the town of Lecanto. Two humer1, four carpometacarpl, three femora, two t1blotarsi (Brodkorb collectlon, Unlversity of Flor1da); and two humer1, two femora, and one tarsometatarsus (Holmes Collection, see Wetmore, 1931). Holman (1958) reports that the fossils lle in matrix derlved from the Paml1co terrace. This is incorrect. The matrix was derived from the W1comico terrace. 
(c) Seminole Fleld, Florida. Ple1stocene; post-W1com1co. From Joes Creek, 46th Avenue N., 72st St. N., St. Petersburg, P1nellas County, Florlda (Wetmore, 1931). \$1x humer1 and one ulna (Holmes collection, see Wetmore, 1931).

(d) Melbourne, Florida. Plelstocene: post_W1comico. From 11ne of contact between strata I and 2. From Country Club Gole Llaks, ciear Melbourne, Brevard County, Florlda (Wetmore, 2931). Two humerl collected by J. W. Gldley in 1928 (Wetmore, 1931), appear to be lost at present.

(e) Vero, Florida. A heterochronle locality: stratum 2 (w1th extinct vertebrates), Plelstocene, pre-Pamlico; atratum 3 (w1thout ext1not rertebrates), Plelstocene or Recent, post_Panl100; "West of Bridge," age unoertaln. All sites in the center of sec, 35, T $32 \mathrm{~S}$, B $39 \mathrm{E}$, Vero Beach, Indian Blver County, Florida (Welgel, 1958). Stratum 2, two humer1, one coracold, and one t1blotarsus; stratum 3, two humer1, one ulna, and one tlblotarsus; "West of Brlage," one humems (Brodkorb collection, UnIversity of Florida).

(f) Warren's Cave, Florida. Prehlatorlo? From floor of Warren's Cave, 8.5 miles NW of Gainesville, Alachua County, Florida. One scapula, one coracold, and one tarsometatarsus (Brodkorb collectlon, University of Floriaa).

(g) Frlesenhahn Cave, Texas. Late Plelstocene. From Frlesenhahn Cave in northern Bexar County, Texas (MIlstead, 1956). Four humer1, one ulna, and two t1blotarsl (Texas Memor1al huseum collection 933-428, 933-447, 933-2186, 
933-3042, 933-3199, 933-3041, and 933-3531).

Lophortyz Bonaparte 1838

Lophortyx cal1forn1ea (Shaw) 1798

Horizon and local1ty.-.-(a) Ple1stocene. From Rancho La Brea asphalt beds in Los Angeles, Los Angeles County, Callforn1a (Howard, 1930; M111er and DelMay, 1942).

(b) Ple1stocene. From Fauna I and Fauna II of asphalt beds, McKlttr1ck, Californla (L. M111er, 1935).

(c) Ple1stocene. From asphalt beds of Carpinteria, Cal1fornia (DeMay, 1941).

(d) Plelstocene. San Pedro and Palos Verdes formations. San Pedro, Cal1fornla (L. M111er, 1914 and 1930; Howard, 1944 and 1949).

(e) Plelstocene. From Hawver Cave, Bldorado County, Cal1fornia (L. M111er, 1911).

Mater1al.--(a) Bancho La Brea; 101 ind1viduals.

(b) McKlttrick; Fauna I, three bones, Feuna II, 93 bones.

(c) Carplnteria; nine 1ndividuals, 102 bones. (d) San Pedro;

San Pedro formation, one coracold, two humerl, one tiblotarsus, Palos Verdes formation, s1x bones. (e) Hawver Cave, 17 bones. Fossils from all the above locallties are in the Unlversity of Californla Museum of Vertebrate Paleontology. Fossils from localities (a) and (d) are also in the Los Angeles County Museum. Lophortyx callfornica is the most abundant foss1l qua11 in the western Un1ted States. 
Cyrtonyx Gould 1844

Cyrtonyx montezumae (V1gors) 1830

Horlzon and Iocal1ty.--Ple1stocene. From San Josec1to Cavern, province of Aramberri, state of Nuevo Leon, Mexico (L. M112er, 1943).

Mater1al..-E1ghty bones, 1ncluding 11mb bones, a coracold, and two crania (University of Cal1fornia Museuw of Vertebrate Paleontology).

Femarks.--According to L. Miller (1943) the fossil sample is very close to the subspecies $\mathrm{C}$. montezumae mearns1. Odontophorus vie11lot 1816

The genus 1s reported frow the Plelstocene of varlous cave in Braz1l, and from a prehistoric site in a Yucatan cave.

\section{Odontophorus gujanens18 (Gmel1n) 1789}

Horlzon and locality.-.Ple1stocene. From four cave deposits (Lapa da Escrivan1a, Lapa da Marinho, Lapa do Periper1, and Lapa Verwelha) near Lagoa Santa, Minas Gerees, Braz1l (W1nge, 1887).

Mater182.-. A few bones from each cave (Copenhagen Museum).

Fordis from Archaeological Sites

Remains of species of American quall $11 \mathrm{ving}$ today are known from several archaeological sites. Dendrortyx leucophrys is questionably 11sted from a cave in Yucatan 
(Fisher, 1953). Oreortyx picta 16 reported frow a cave in New Mexico (Wetmore, 1932). Col1nus V1rg1nianus is 1dent1fled from caves in Tennessee and Texas (Shufeldt, 1897; Wetmore, 1933), and c. n1gropular1s is reported from a cave 1n Yucatan (F1sher, 1953). Lophortyx cal1fornlca and I. gambel11 are 11sted from Indian sites in Californ1a and Arlzona (DeMay, 1942; Wetwore, 1932). Odontophorus guttatus is questionably 1dentifled from a cave in Yucatan (F1sher, 1953).

\section{Variation in Fossil Colinus}

Wetwore (1944) named Colinus hibbardl from the upper P110cene of Meade County, Kansas, and Brodkorb (1959) described Colinus sullium from the pre-W1comico. Plelstocene of Arredondo, Florlda. These specles were described on the bes1s of large s1ze and several qualitat1ve characters. Additional specimens of C. hibbardl aud C. sullium were reported by Tordoff (1951a) and Holman (1959c). As polnted out by Brodkorb (1960), in all probabll1ty these forms are the temporal equivalents of 11ving Colinus virginianus, and we are deal1ng with a continuum. Because the 11ving speoles of Collnus are almost 1dentical to each other in osteological characters and exhlbit aubspecific variation in $81 z \theta$, it is extremely difficult to arrive at texonomic decision regarding where to draw the line between certa1n fossil populations of colinus. 
The variations found in fossil Colinus are discussed in the following paragraphs. It should be polnted out that the samples of fossll bones from many locallties are too small to be statiatically slgnifloant.

\section{Qualitative Characters}

Qualitat1ve chameters of foss1l and Becent Collnus are sumwarized below.

Coraco1d.-.The head of the coracold is reflected in the single foss1l of $\mathrm{C}$. hibbard1, 1n 63 per cent of 62 foss1ls of C. Bullium from Arredondo, Orange Lake, and Redalok, and in 92 per cent of 86 modern specimens of C. V1rginlanus and the two specimens of modern C. nigrogularis. It 18 inflected in two of three specimens of modern C. leucopogon.

The procoracold process is weakly developed in C. h1bbardi and 28 stronger in C. sullium, C. p1rginianus, C. n1grogular1s, and c. leucopogon.

Scapula.-.The dorsal depression just mediad to the glenold facet is deep in 67 per cent of 15 fossils of $\underline{C}$. sul11um from Arredondo, Orange Lake, and Beddiok, but is shallow in 77 per cent of 81 modem speciwens of $\mathrm{C}$. Virginianus. The depression 18 deep in one of two specimens of I1ving C. nigrogularis, and two of three specimens of 11ving c. leucopogon.

The bridge between the acromion process and glenold facet is usually about one-half the wiath of the glenold 
racet in C. sul11um, C. v1rginlanus, and C. leucopogon, but 1s less than one-third the width of the glenold racet in $\mathrm{C}$. n1 grogular1s.

The acromion process 18 strongly inflected in 62 per cent of 13 foss1ls of C. Buillum from Arredondo, Orange Lake, and Beddick. In the 11ving species the process is only slightly inflected in 72 per cent of 80 specimens of $\mathrm{C}$. v1rginlanus, in one of two C. n1grogular1s, and 1n two of three $C_{\text {. }}$ leucopogon.

Humerus.--The ridge along the medial border of cossa II 18 moderately swollen in fossil C. su1l1um, modern c. V1rginlanus, and modern C. leucopogon, but 18 only slightly swollen in modern C. nigrogular1s.

The blclpital crest 18 pointed in 51 per cent of 97 foss1ls of C. sull1um from Arredondo, W1111ston, Orange Lake, and Bedd1ck. It 18 rounded in 69 per cent of $83 \mathrm{spec1-}$ mens of IIving C. V1rginlanug, in the single speolmen of $\mathrm{C}$. nigroguiaris, and in the three specimens of $11 \mathrm{ving}$. . leucopogon.

The enteplcondyle arises abruptly from the shaft in 20 per cent of 107 foss11s of C. sull1um frow Arredondo, W1111_ ston, Orange Lake, and Reddlok. The enteplcondyle arises gently from the shaft 1 n 97 per cent of 77 specimens of modern C. virg1nianus and in the three specimens of $\underline{C}$. leucopogon.

The depression for $M$. brachlal1s ant1cus is very large 
1n C. nibbardi, and in two of four foss1ls of C. suillum from Arredondo, but it is small in the 11ving specles of Col1nus.

Carpometacarpus.--The process of metacarpal I $1 \mathrm{~s}$ polnted in the single fossil of C. h1bbard, and in 63 per cent of 35 fossils of C. su1l1um from Arredondo, W1211ston, Orange Lake, and Beddick. It 1s polnted in 93 per cent of 44 specimens of $11 \mathrm{ving}$ C. V1rginlanus, but 18 rounded in the three speclmens of C. leucopogon.

The p1siform process is wuch reflected dorsad and thus produced well above the dorsal rim of the lnuer carpal trochlea in 25 per cent of 32 fossils of C. sulllum from Arredondo, Orange Lake, and Redalck. The process 18 slightly reflected dorsad and thus below or at the level of the 1nner carpel trochlea in all living species.

The notch between the proximal border of the process of metacarpal I 18 deep in the single rossil of C. h1bbard and In 80 per cent of 35 fossils of c. sullium from Arredondo, Williston, Orange Lake, and Reddick. The notch is slight in 71 per cent of 48 specimens of $11 \mathrm{ving}$ C. V1rginianus and in two of three specimens of living $C$. leucopogon.

Tiblotarsus.--The posterior margin between the external and Internal articular surface is deeply notched in 28 per cent of 18 foss1ls of C. sull1um from Arredondo, Orange Lake, and Reddick. The notch 18 shallow in all specimens of the three 11ving species. 
Quantitative Characters

Two types of size trends occur in the genus Colinus. A geograph1c decrease in s1ze occurs from north to south, w1th M1chigan quall the largest, and southern Florlaa quall the smallest (Table 8 ). A temporal decrease in mean size occurs from late P110cene to the present.

Collnus hlbbardi from the upper P110cene of Kansas 1s the largest known Colinus, and quall from the Plelstocene of Florlda are uaually larger than thelr Recent geographlc representatives. Fossils asigned to the species C. 'su121um from Arredondo, W1211ston, Orange Lake, and Reddick, Florida, are decldedly larger than quall living in those places today (Table 9). They average as large as or larger than Becent Col1nus V1rglnianus from Mich1gan in wost measurements (Arredondo, 19 of 20 measurements; W1111ston, 11 of 12 ; Orange Lake, 17 of 17 ; and Beddick, 16 of 20). A few bones tentatively assigned to $\mathrm{C}$. Bu1lium from Ha1le II, Oakhurst Quarry, Elchelberger Cave, and Lake Monroe, Flor1da, are also simllar in $81 z e$ to living C. V1rginlanus V1rginlanug frow Michlgan, and a single bone from Zuber, Florlda, tentatively assigned to c. sulilum, is similar in size to I1ving C. V1rg1nianus v1rginlanus from IIIIno1s.

Foss1ls assigned to C. Virglnianus from Kanapana, Saber-tooth Cave, the Vero strata, and Warren's Cave, Florida, are about the size of their Becent geographic representatives. Bones assigned to c. V1rginianus from the 


\section{6}

Plelstocene of Frlesenhahn Cave, Texas, are only slightly larger than Becent bob-whiteg from northern Florida.

Recent and fossil species of Collnus are 1nseparable on 1nterwembral and 1ntramembral ratios (Tables $2-6$ and 10_13), with the exception of one fossil humerus from Oakhurst Quarry near Ocala, Florlda, whloh is slightly shorter and stouter then in other Becent and foss1l Col1nus. 


\section{CONCLUSIONS}

The American quall form a natural group that has undergone an independent evolution in the New World. The following hypothetical outline of the course of events is based upon the osteology of the IIVLng species and on the fossil record.

The families of 11ving Galli were differentlated very early in the Tertiary period. Fossils representing the Cracldae (Gallinuloldes Eastman; see Tordoff and Macdonald, 1957), the Phaslanidae (Palaeortyx M1lne-Edwards), and the Tetraonidae (Palaeophasianus Shufeldt) are recorded from the Eocene. The Meleagrididae (Meleagr1s ant1qua Marsh), and the Odontophor1dse (1ndeterminate odontophorid, Tordoff, 1951) are represented by O11gocene fossils.

The hypothet1cal ancestor of the Odontophoridse must have been very close to the stock from whloh the pheasants and grouse arose. It probably was in the following stage of skeletal evolution. The size was relatively large, and the rostrum was short and deep. The sternum was characterlzed by deep notches, long parallel anterior lateral processes, moderately pneumatic sternal plate, and reduced dorsal foramen of the manubrial spine. The coracold had a ventrally overhang1ng brachlal tuberos1ty, w1th the dorsal 
Intermuscular line slightly ralsed distally, and the ventral intermuscular ine encroaching on the sterno-coracoldal process, whose tip was w1 thout a terminal knob. The scapular blade was elongate and had the beglaning of a dorsal groove. The huwerus hac moderately large pneumat1c fossa w1th a reduced 1nner shelf, and fossa II was st111 1ndistinct. The carpometacarpus had a moderately produced p1s1form process and a well developed 1ntermetacarpal tubercle that did not reach the level of metacarpal III. The pelvis had a small pneumatic fossa on the anterior portion of the renal depression, and the pectineal process was small. The hypotarsus had only one closed calcaneal canal, and the 1nner calcaneal ridge was without a distal extension or spur core.

By 011gocene time the two basic types of pelvis had probably become established, since the single known 011gocene ross1l already resembled speclallzed modern forms. By the Mlocene fossa II of the huwerus was starting to develop, as shown by M1ortyx teres. A vestige of the 1nner shelf of the pneumatic fossa of the humerus was st1ll present in the middle Pllocene Lophortyx shotwell1.

The Odontophoridae are presently at the following stage of evolution. They are generally the smallest of the Gell1. The rostrum is relatively short and deep, with this condition reaching 1 ts culmination in Bhyrichortyx. The sternum is deeply notched, with long, narrow, parallel 
anterlor lateral processes; the pneumaticlty of the enterlor sternal plate and the dorsal manubrial foramen has been lost. The coracold has an overhanging ventral portion of the brachial tuberosity and a sharply ralsed dorsal 1ntermuscular. IIne; w1th one exception the termination of the ventral 1nterwuscular Ine of the coracold haa shirted to the tip of the sterno-coracoldal prosess, whlch now ends in a terminal knob. The scapular blade is very long and has a deep dorsal groove. The humerus has a large pneuwat1c fossa, whose 1nner shelf is completely lost, except 1n. one species of Odontophorus; fossa II is well developed 1n all genera but Dendrortyx and Odontophorus. The carpometacarpus has a produced pls1form process, and the 1ntermetacarpal tubercle extends to metacarpal III In all but a few Individuals of Cyrtonyx. The pelv18 has lost the pneumat1c fossa in the renal depression, and in the Odontophorus group the pectineal process is further reduced or even lost. Flablly, the hypotarsus has developed a second closed calcaneal canal in most genera.

In the best known genus, Colinus, there has been a progressive trend, from late Pliocene time to the present, toward reduction in size and gradual change in qualitative characters. Collnus h1bbard1 from the upper P11ocene of Kansas is the most distinct spec1es of Collnus on the basis of 1 ts large size and qualitative osteological characters. Collnus sull1um from the pre-W1comlco Plelstocene of 
Florida is somewhat smaller than c. hlbbardi and has fewer qualitative osteologioal characters. Fossils of latest Ple1stocene age are 1dent1cal w1th 11 ving C. v1rginlanus, except for their slightly larger size. The ohange from $C$. hibbard1 to c. sull1um apparently took place durlng the early Plelstocene. The transition from C. sullium to $\mathrm{C}$. virginlanus occurred in W1comico time and was probably Inltiated by the change from glacial to interglacial ollmate. 


\section{SUMMARY}

The fam1l1es and subfamilles of the suborder Gall1 are redefined on the basis of osteological characters. The skeletons of 11ving genera, spec1es, and subspec1es of New World quall are described, and osteologlcal criterla are established for the varlous taxa.

Certa1n changes are proposed regarding the classif1cation and relationship in the suborder. Within the suborder Galli the families Numldidae and Meleagrididae are placed nearer the primitive family Cracldae, and the Tetraonldae are placed in a higher position near the Phaslanldae and New World quall. The New World quall are recognized as separate fam1ly, the odontophorldae, and represent the most speciallzed b1rds in the suborder Gall1.

The fam1ly Odontophoridae is divided Into two distinct groups on the besis of pelvic structure. The Dendrortyx group contalns Mlortyx of the Miocene, Neortyx peninsularis n.g. n.sp. from the Plelstocene, and the IIving genera Dendrortyx, Ph1lortyx, Oreortyx, Cal11pepla, Col1nus, and Lophortyx. Dendrortyx 18 at once the most primitive and aberrant 11ving genus of American quall and 1s most closely related to Phllortyx. Oreortyx 1s near relative of the Call1pepla-Col1nus-Lophortyx complex of genera. The genera 
In the latter complex are so simllar that they might be best considered as subgenera.

The Odontophorus group contalns the 11ving genere Odontophorus, Dactylortyx, Cyrtonyx, and Bhynchortyz. Odontophorus appears to be the most primitive genus in this Broup. Dactylortyx and Cyrtonyz are s1m12ar. Bhynchortyx 1s the most aberrant genus of the Odontophorus group. The Mlocene specles Cyrtonyx tedfordi should probably be transferred from the Odontophoridae to the Cracldae. The study of more than 700 fossils of the genus Colinus show a progressive trend toward reduction in size and gradual change in qualitative characters. The transition from C. hibbardi to C. sullium took place during the early Plelstocene, and the change from C. sullium to C. Plrgln1anus occurred in w100mico time. 


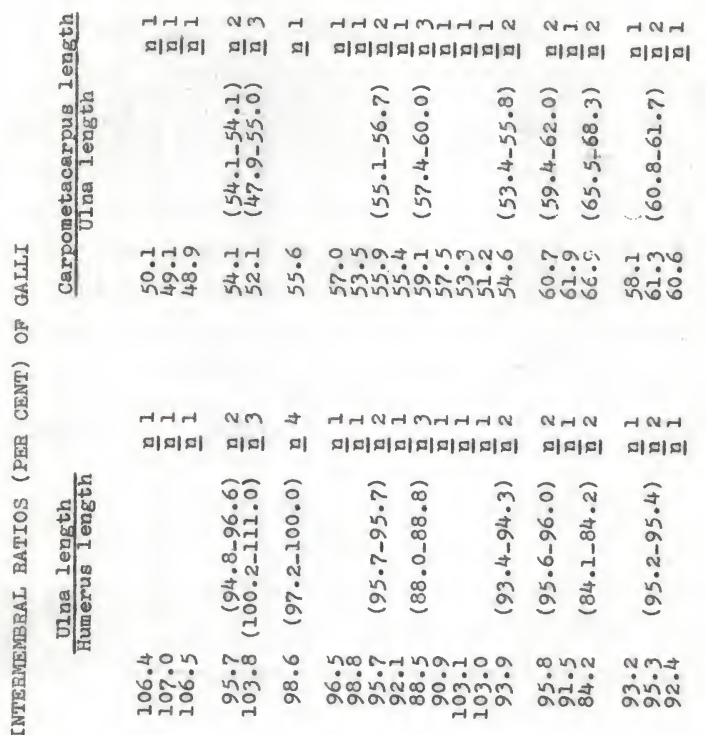



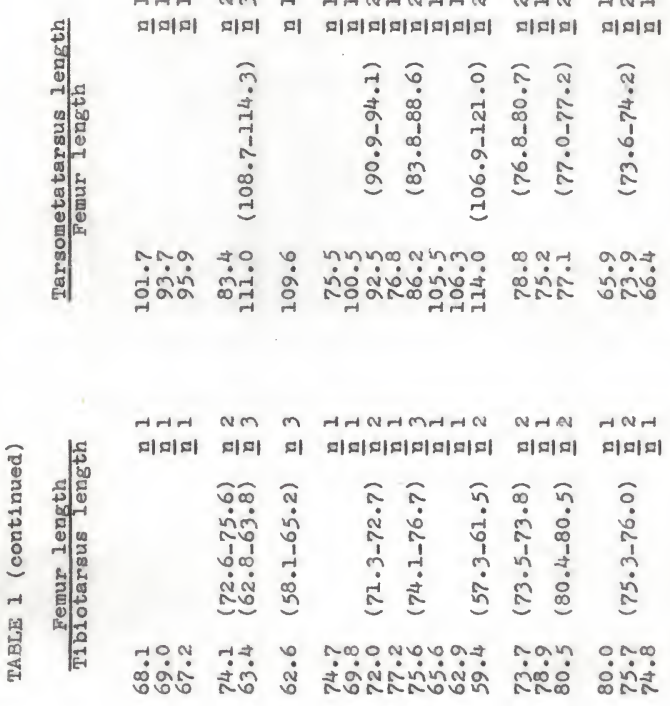

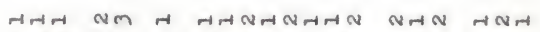

$$
\begin{aligned}
& \text { 미미미 미미 미 미히미미미미미미 미히미 미미미 }
\end{aligned}
$$

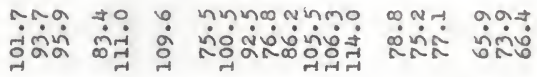

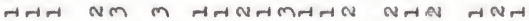

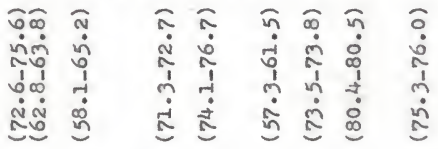

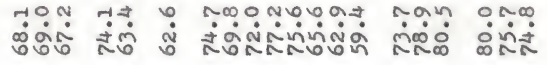

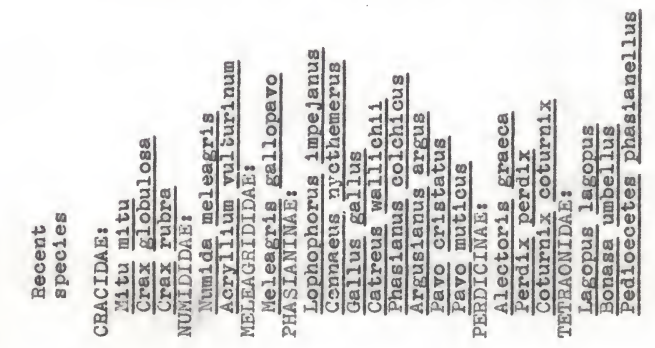


我我

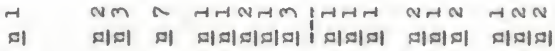

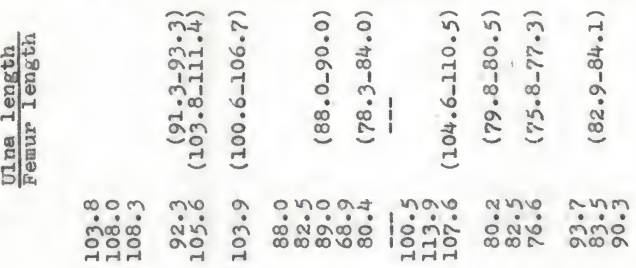

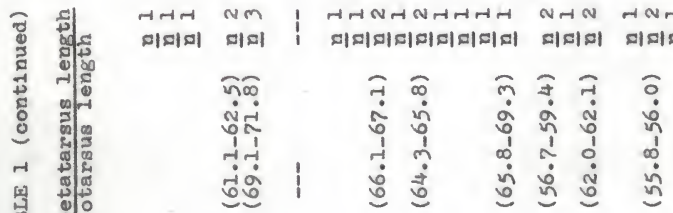

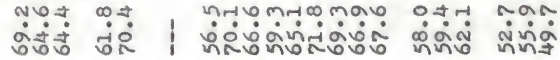

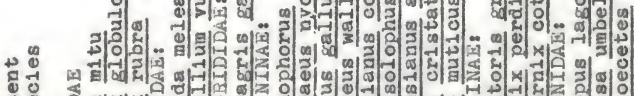

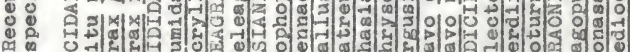

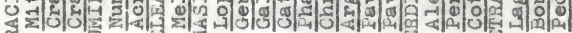
लु 

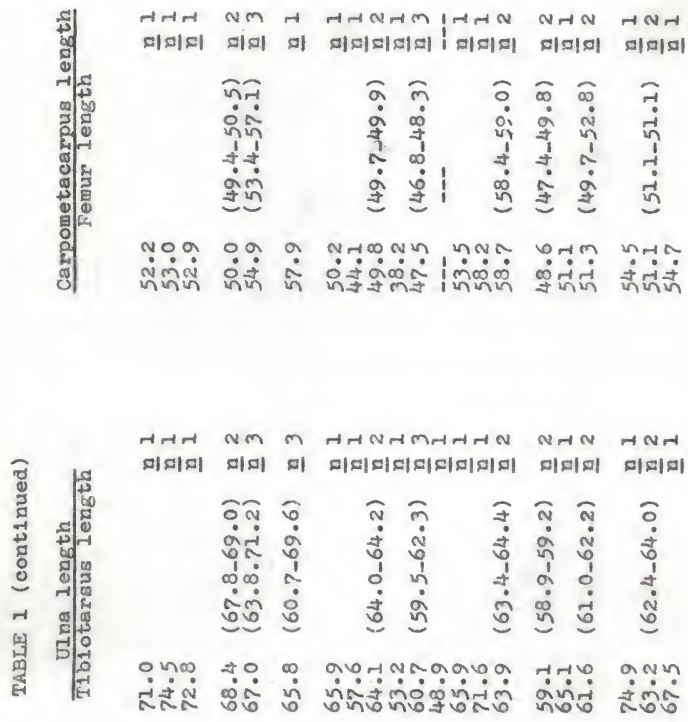


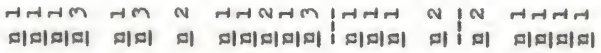
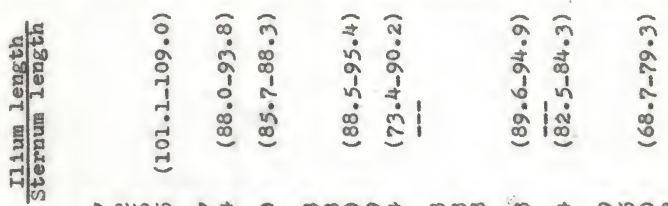

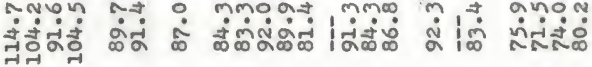

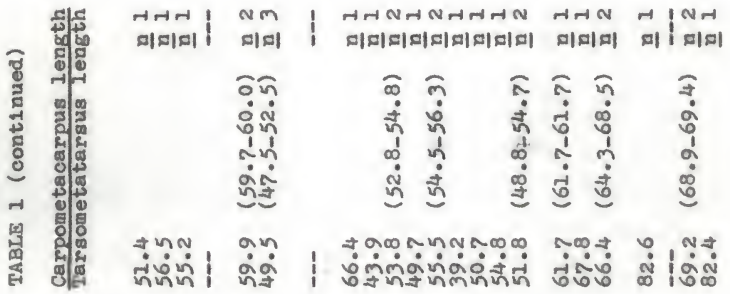

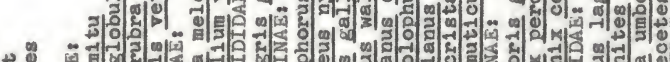
궁

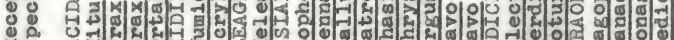

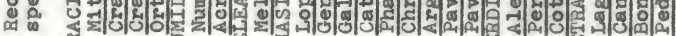
खु 


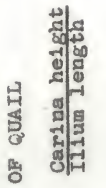

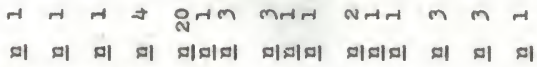

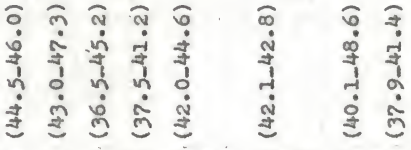

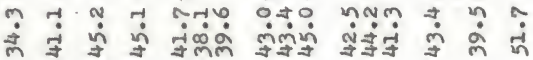

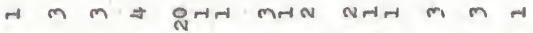

미 미 이 하 미미미 미미디 다티미 미 미 디
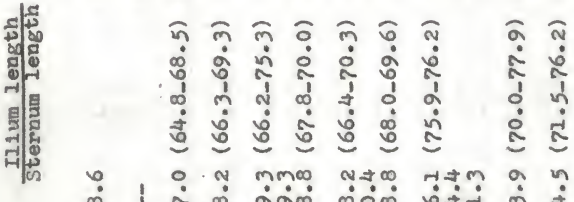

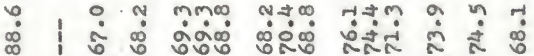

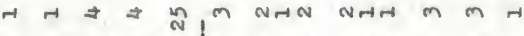

히 히 미 마 비 미 히미미 히미미 비 미 미

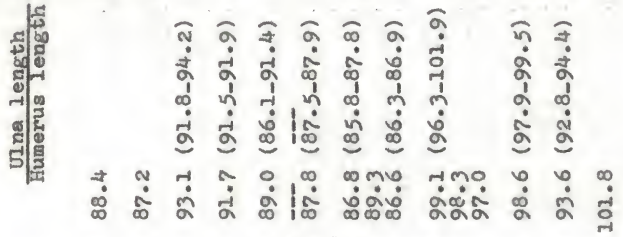

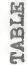

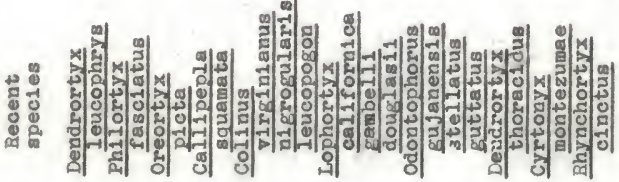




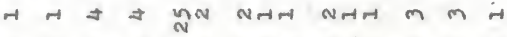

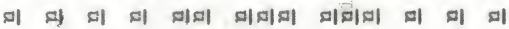
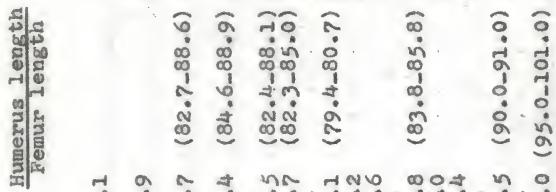

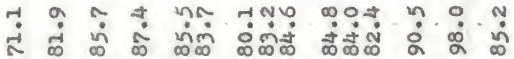
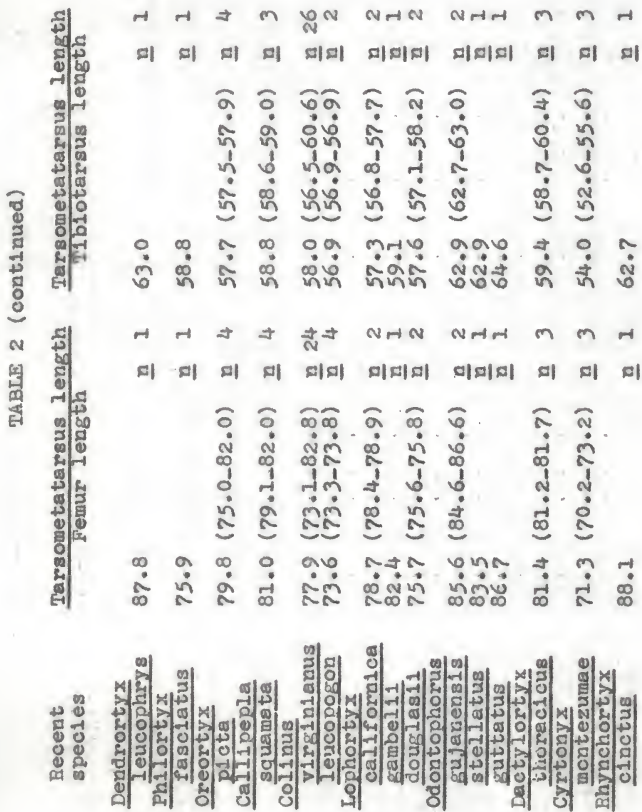
|c

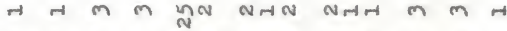

히 히 ㅎा 미 미미 미미미 미마미 미 미 미

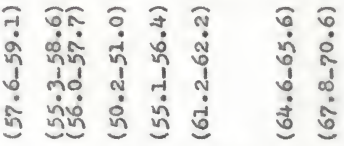

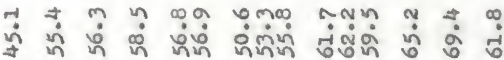

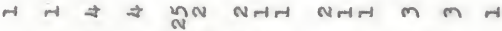

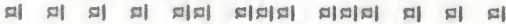
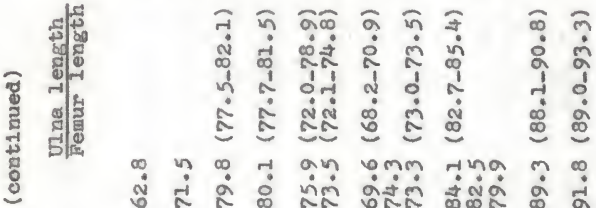

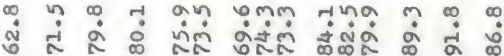

要

c)

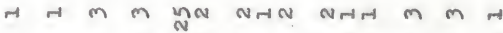

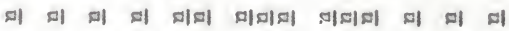

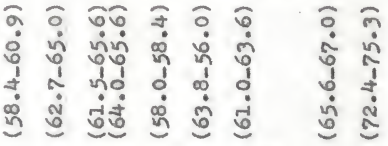

ํํ

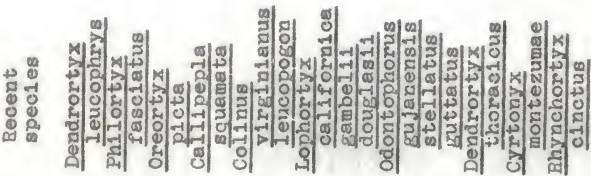



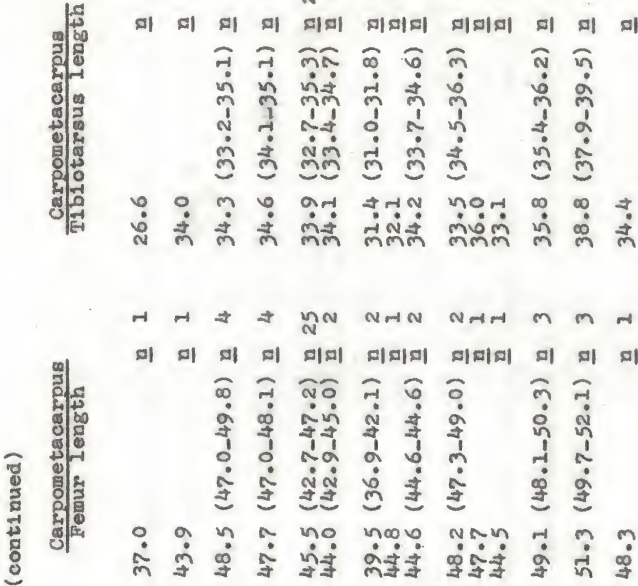

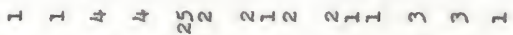

미 미 미 다 미미 티미미 디미미 미 미 미

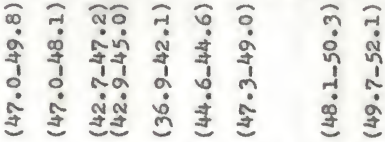

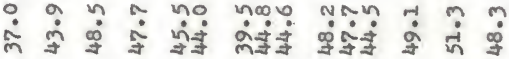

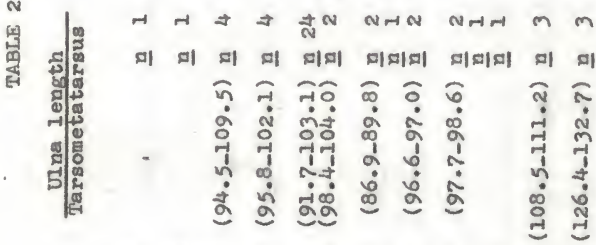

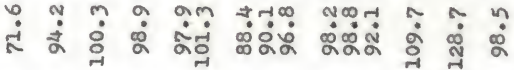

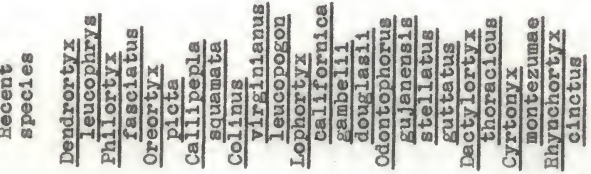




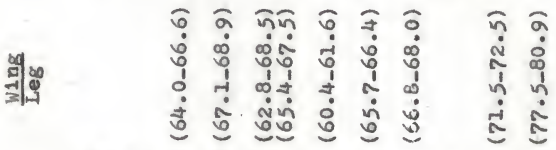

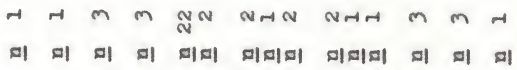

๗๐

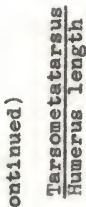

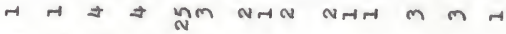

히 히 미 히 미티 미미미 미히미 히 히 미

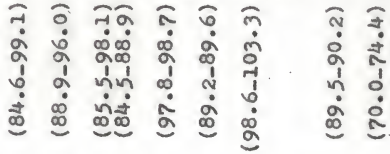

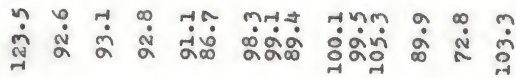

$-H \Rightarrow$ \&

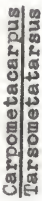

미 미 미 미 히미 삐티미 디미미 미 히 미

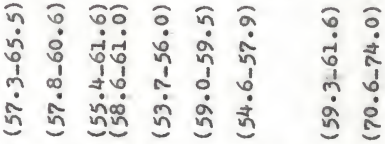

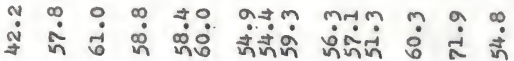

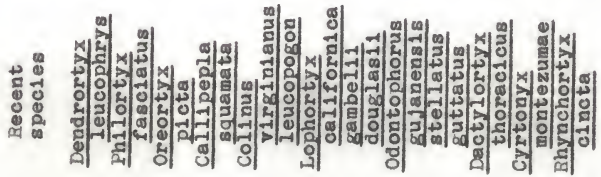




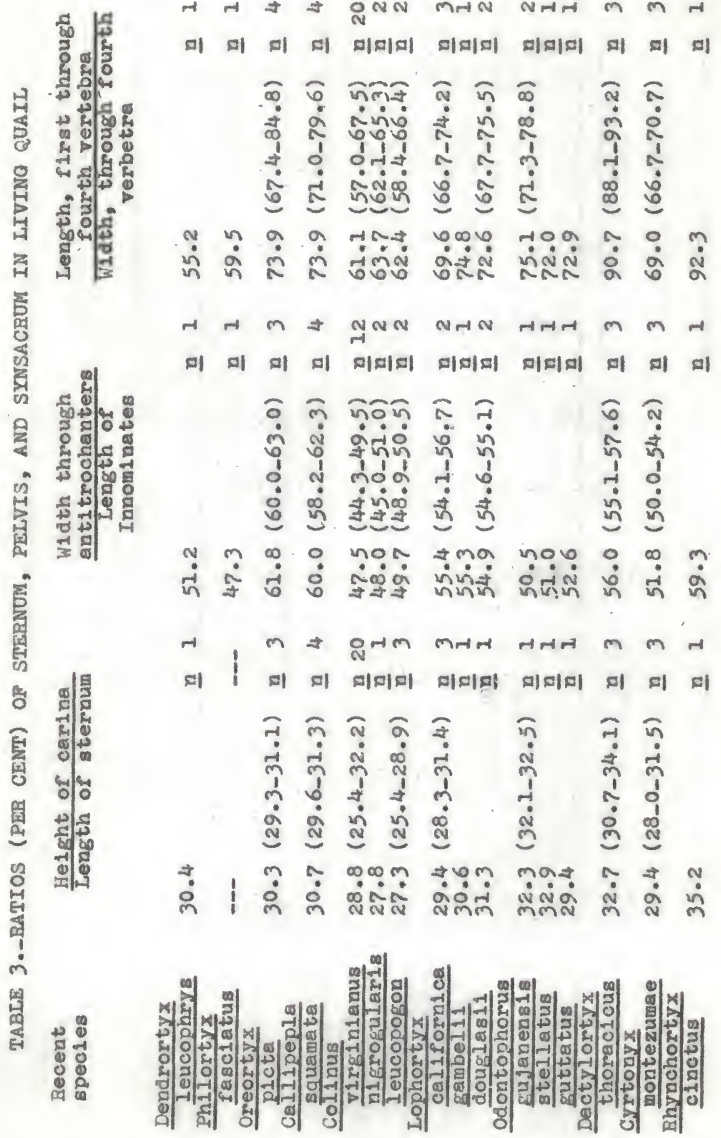



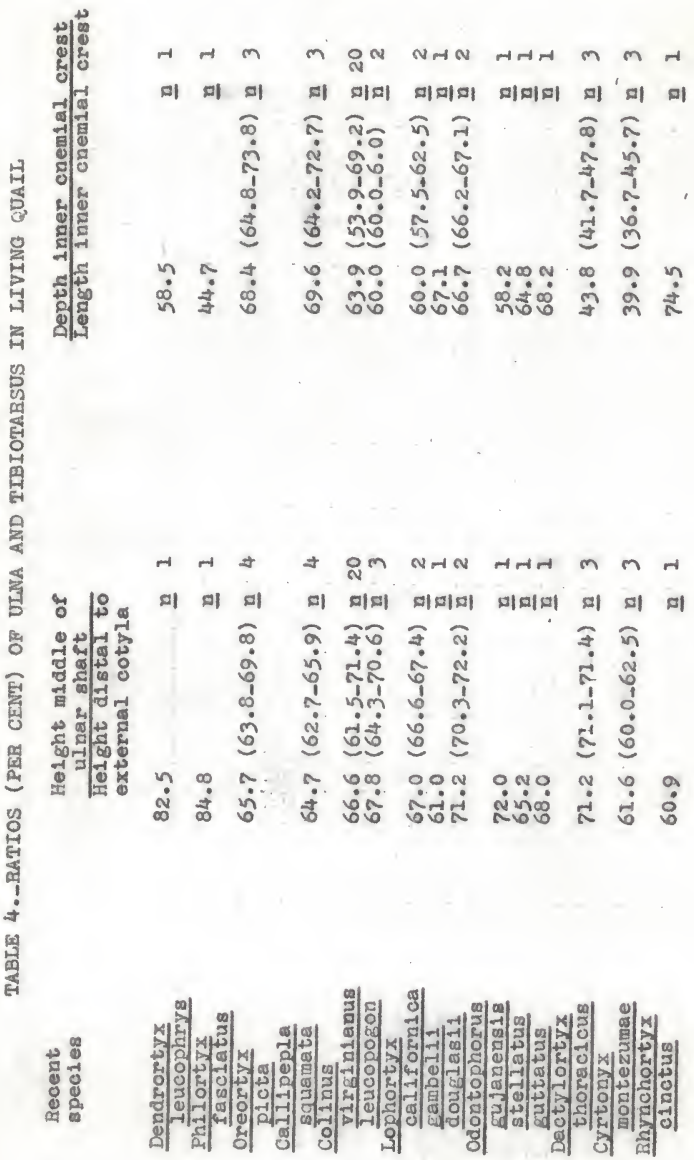


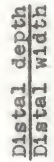

要

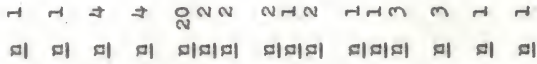

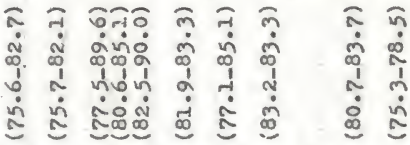

๘ $H-7 \Rightarrow$ ONN NHN NHA M $M-1$ 미 미 티 미 미티미 미미미 미미미 히 이 디 우되됴 की ㅁำ $0 \rightarrow-1$ 约 ठํำ \&

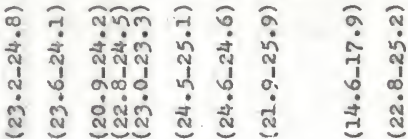
‡ $H H \Rightarrow$ \& NN NHN NHA $m$ M

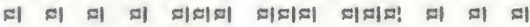

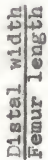

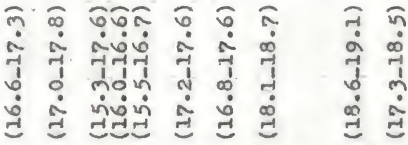

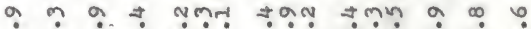

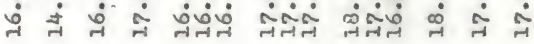

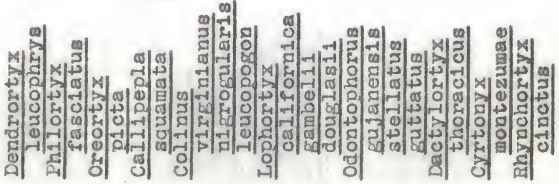




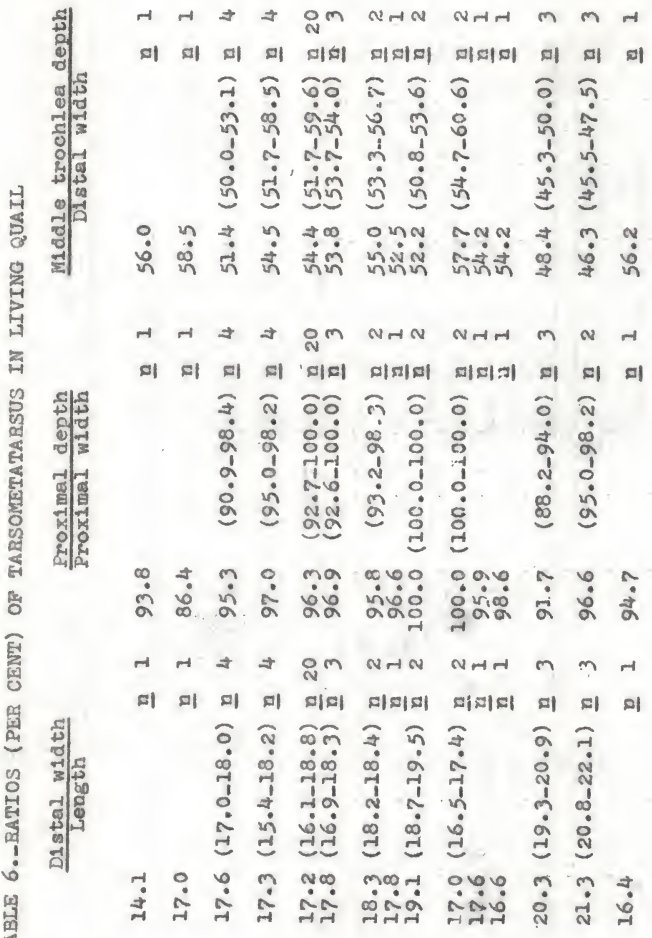

है

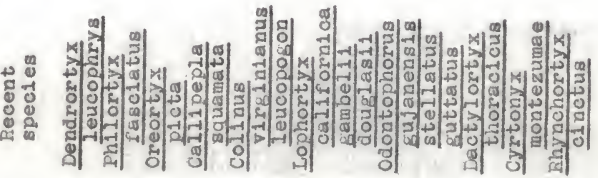




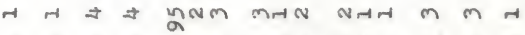

미 미 미 티 미미티 미미며 티미미 미 이 마

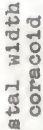

त्रिभ

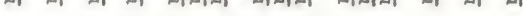

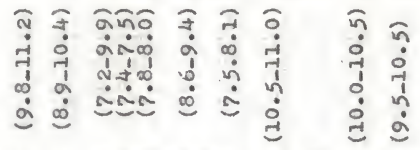

8

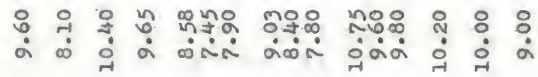

농

盗

赶

范

孛

票

这

z

है

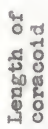

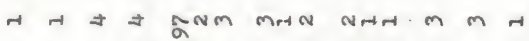

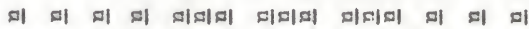

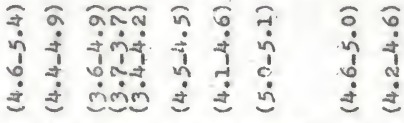

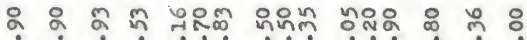

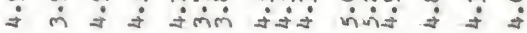

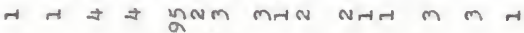

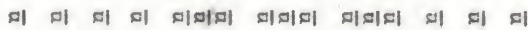

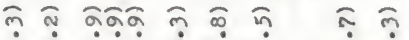

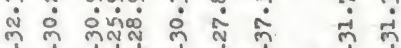

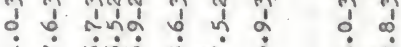

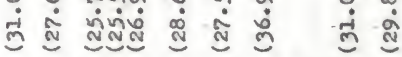

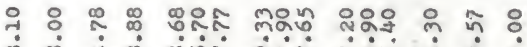
m

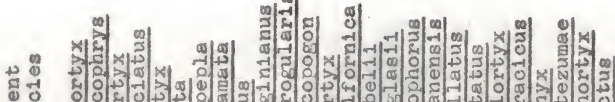

9 0 이의

$0 \%$ \&

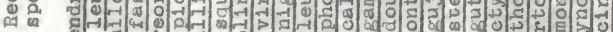

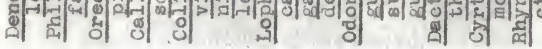


范

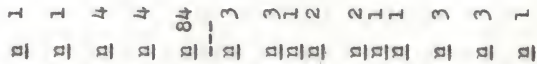

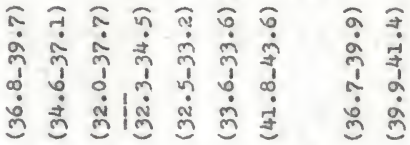

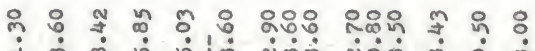

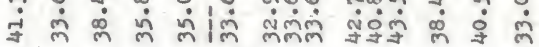

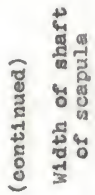

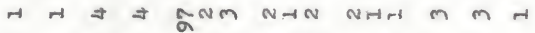

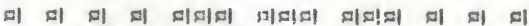

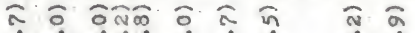

$\dot{\gamma} \dot{i} \dot{i} \dot{\gamma} \dot{\gamma} \dot{\gamma} \dot{\gamma} \quad \dot{\gamma} \dot{i}$

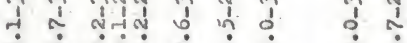

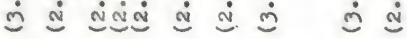

$\sim$

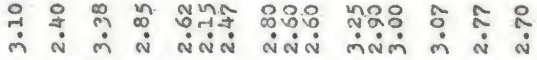

है

$H \mathrm{H} \Rightarrow \Rightarrow$ gNm NHN NHA M M H

竎

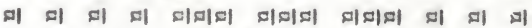

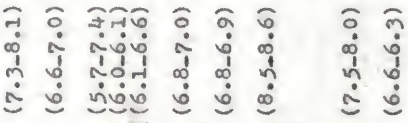

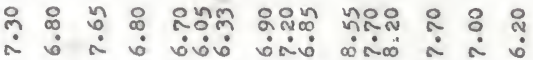

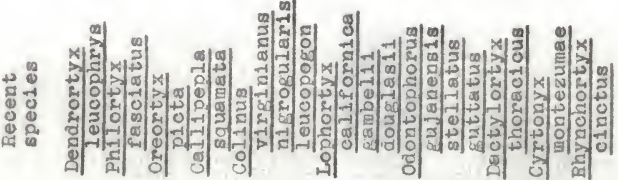


晖

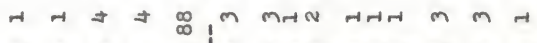
이 이 미 미 이 미 미미미 미미미 이 이 미

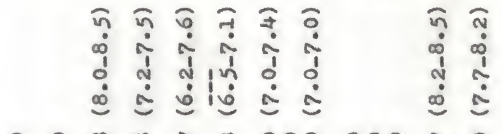

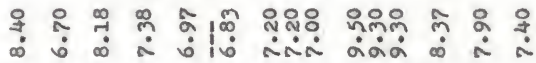

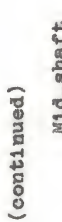

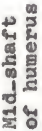

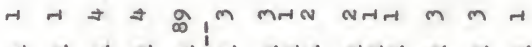

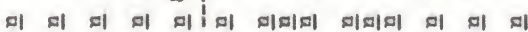

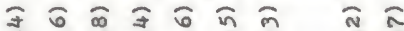

चे

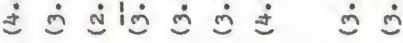

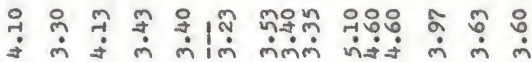

N

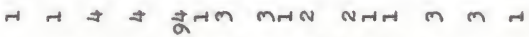

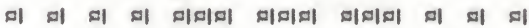

孪

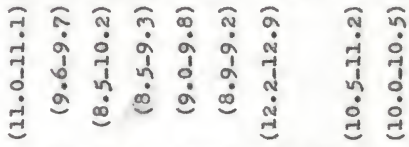

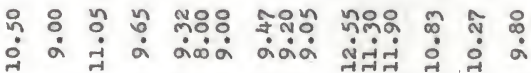

\%

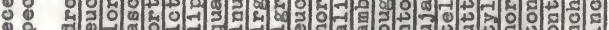

œ

वा क्या क्षै 

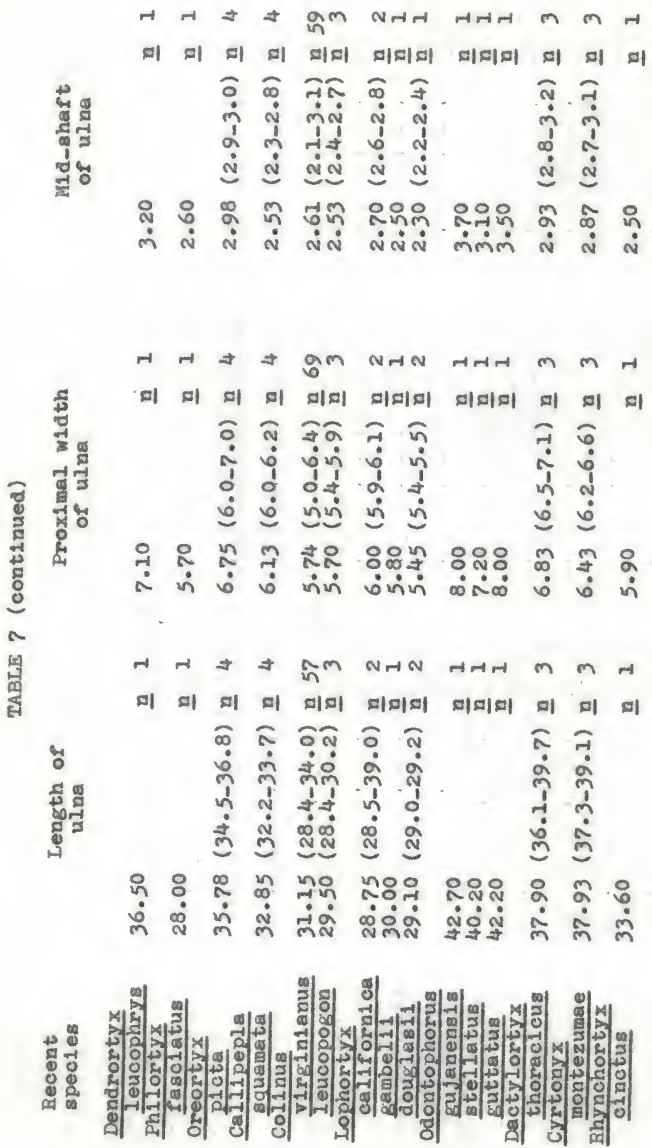


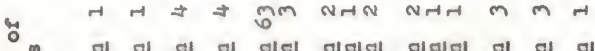

4 미 미 다 마 미티 미미티 미미미 미 디 미

हैं क्षे

개

ב

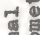

䨌

है
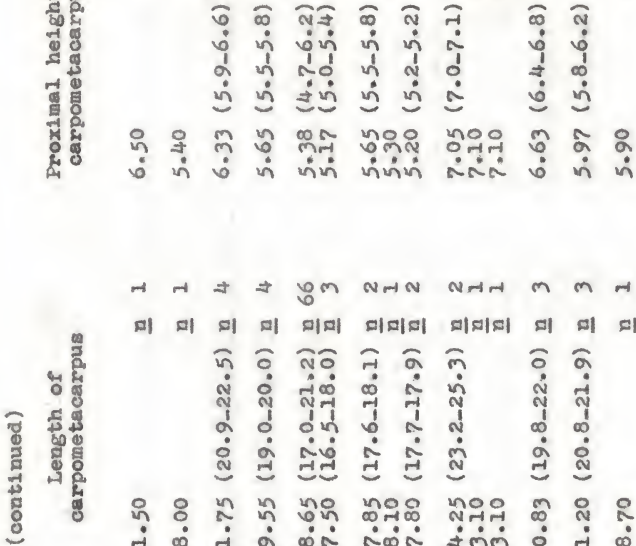

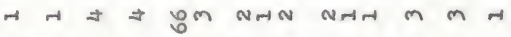

미 미 이 미 미미 미미미 미티티 히 히 히

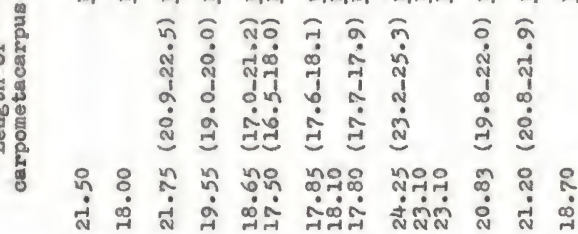

罂

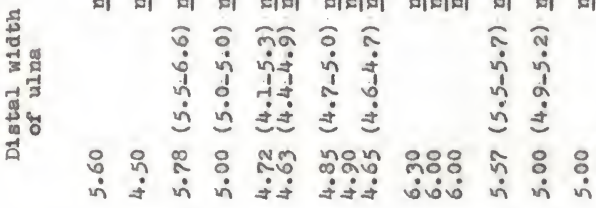

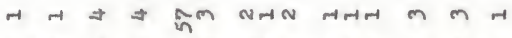

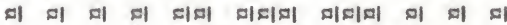

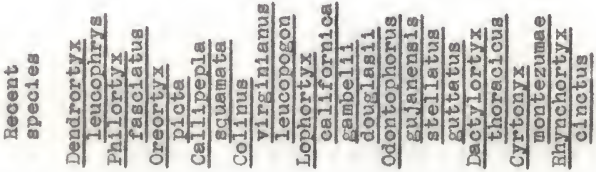


4.

s

$\$$

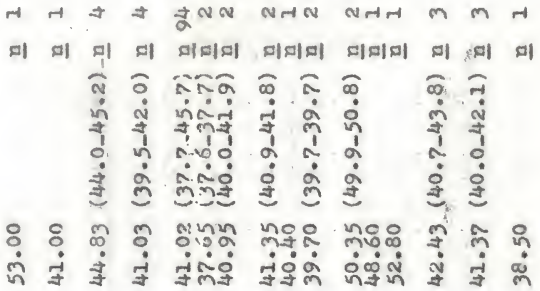

ธี้

क

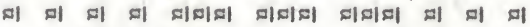

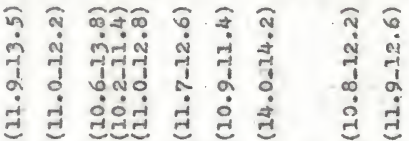

됴용

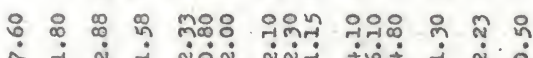

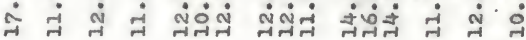

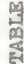

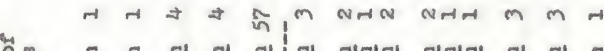

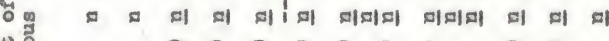
म -18 元 20 용 $\$$ 도

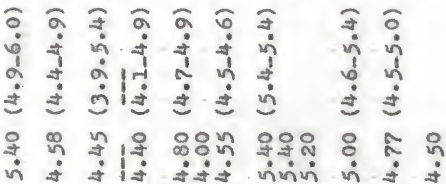

承

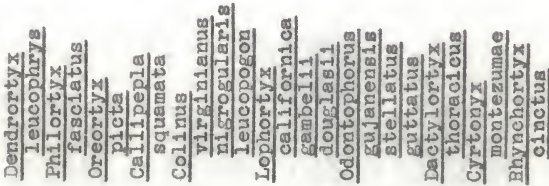



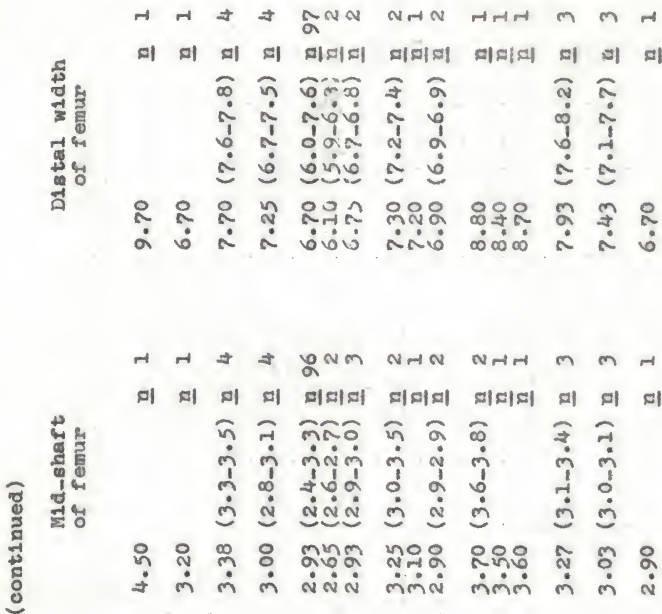

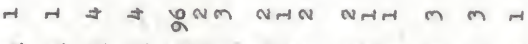

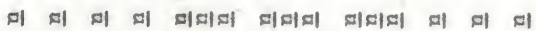

है

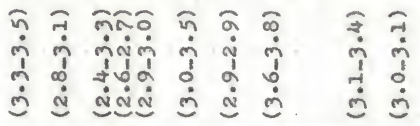

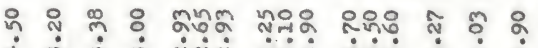
- $\dot{m} \dot{m} \dot{\mathrm{N}} \dot{\mathrm{N}} \dot{\mathrm{m}} \dot{\mathrm{N}} \dot{\mathrm{m}} \dot{\mathrm{m}} \dot{m} \dot{\mathrm{N}}$

क्ष

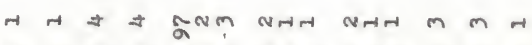

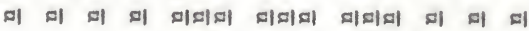

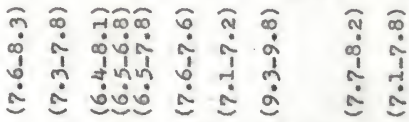

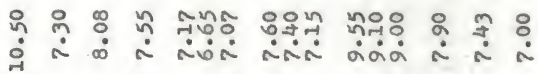

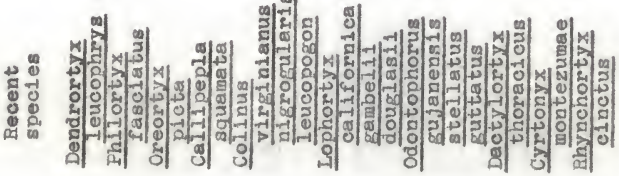




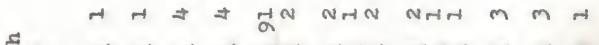

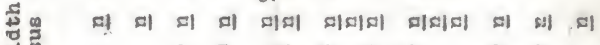

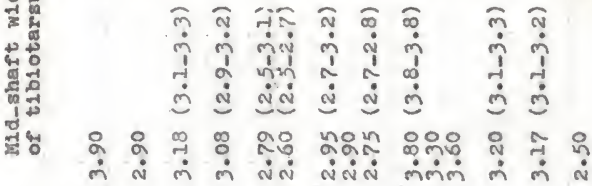

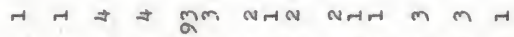

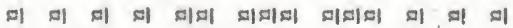

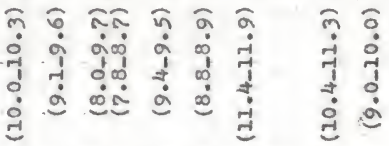

$\therefore$ ำ $\because$ ก

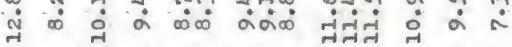

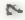

설

$$
\begin{aligned}
& \text { h H m a क }
\end{aligned}
$$

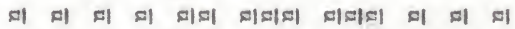

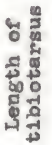

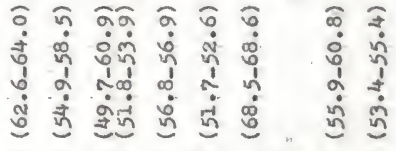

요 우 $\dot{\infty}$ ஸे

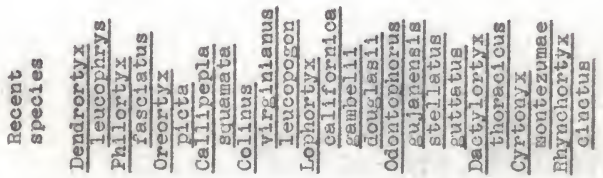



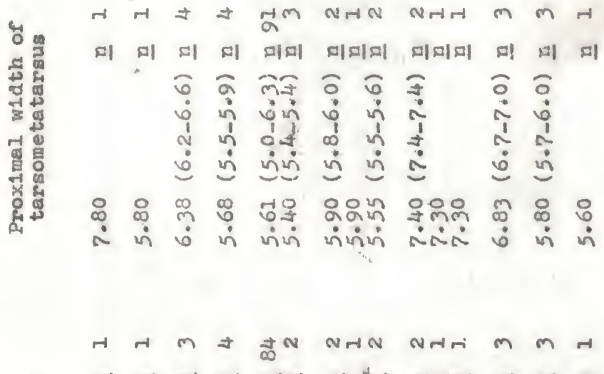

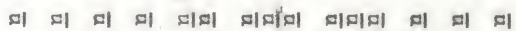

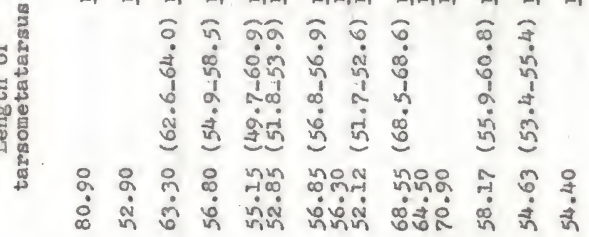
N

且
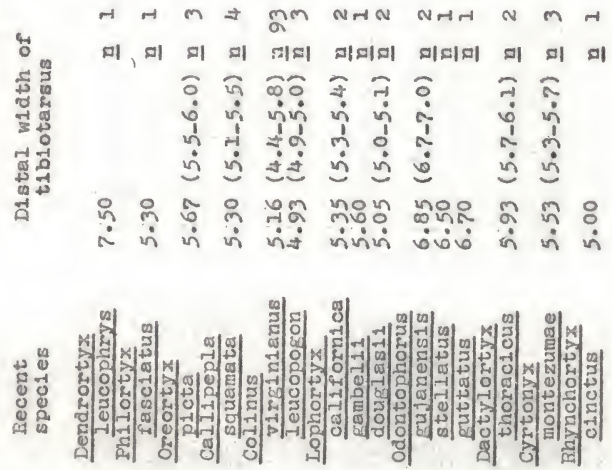


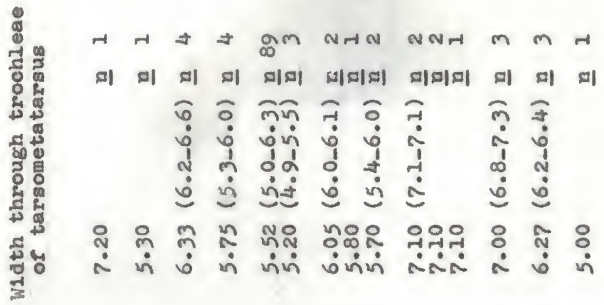
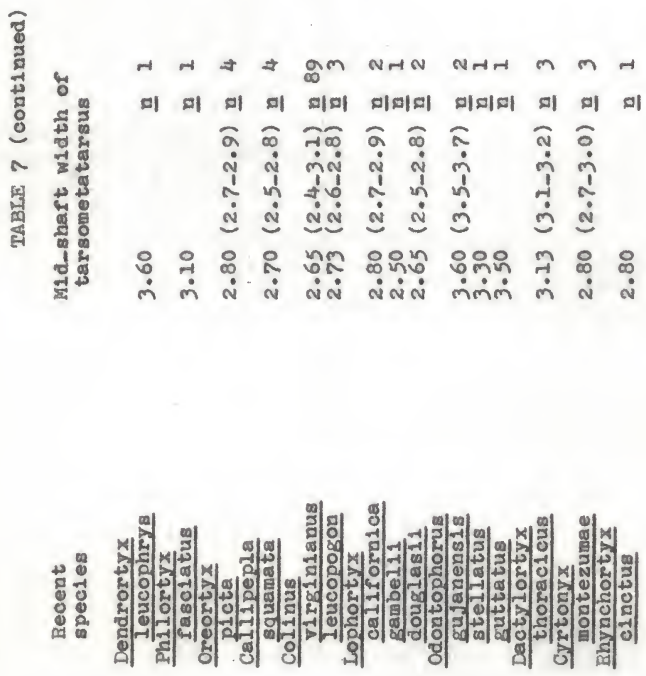
வ

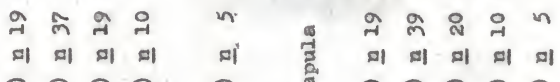

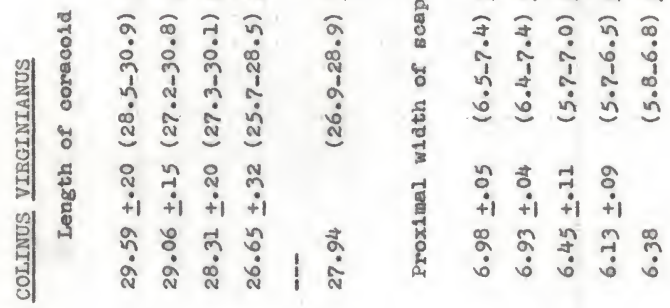
学

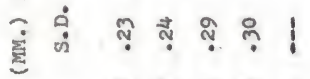

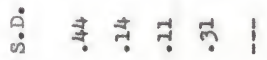

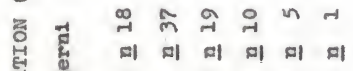

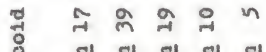

ஐ 仓ิ

हึ.

क घं

ㄴํㅇ ㅎํㅇ

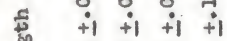

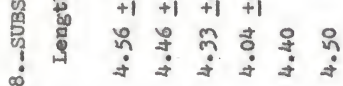

일 이 미 이 이

볐

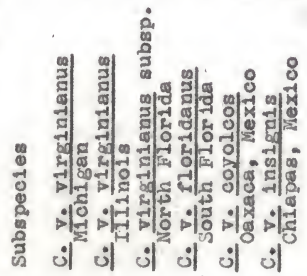

¿ ลิ ธุล ลิ

\& $\quad$ í

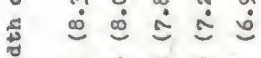

ปี न

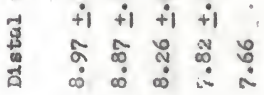

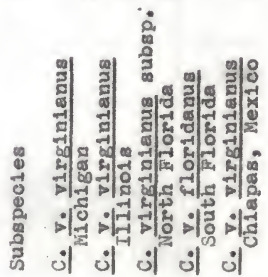




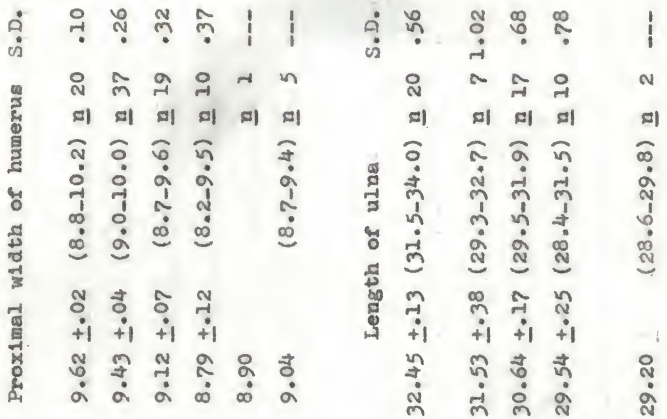

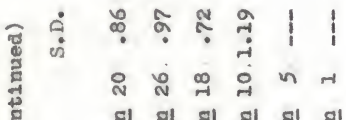

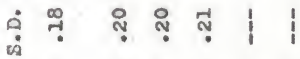

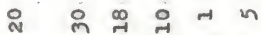

디 뗴 히 히 히 이

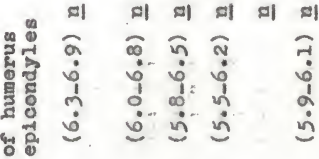

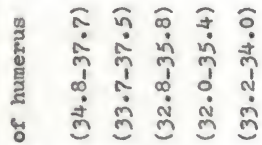

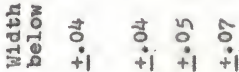

起

$+1+1+1+1$

$+1+1+1+$

ง

$\ddot{m} \dot{m} \dot{m} \dot{m} \dot{m}$

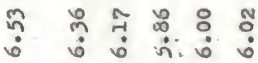
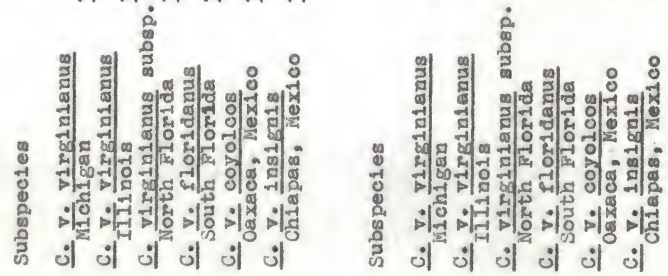
ตุ

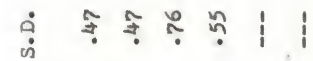

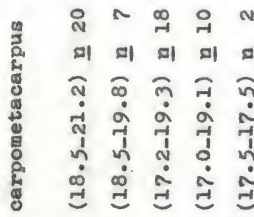

เิ Эิ ๆ ๆे

5 $+1+1+1$

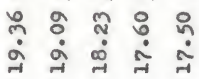

$\frac{5}{8}$

o 0 \& 0 in

미 미 히 티 ㄸ! 티

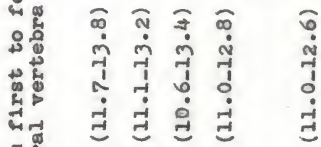

용 क

$4 i^{2}+1+i+1+1$

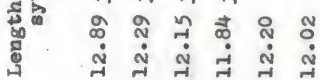

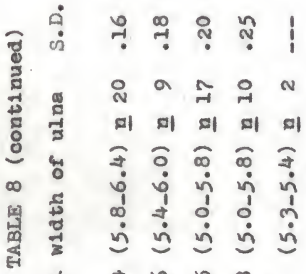

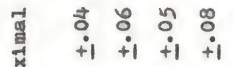

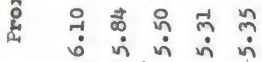

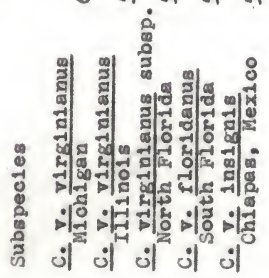

요

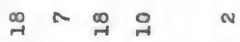

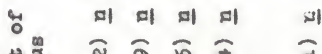

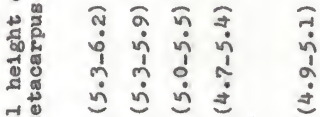

整

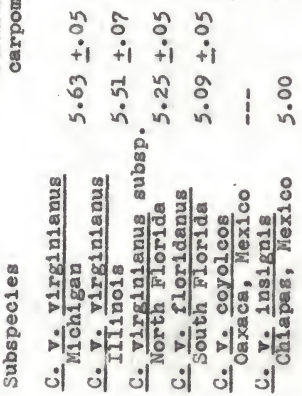


เุ๋

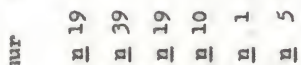

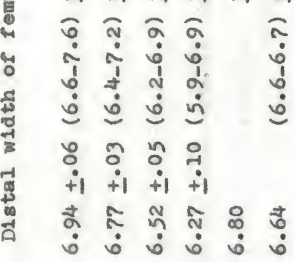

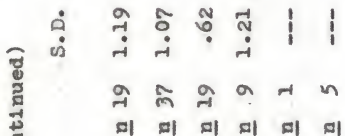

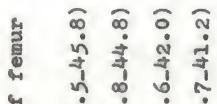

¿

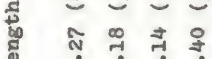

$\Phi+i+1+1$

ทำ สิ ๆ ำ

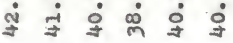

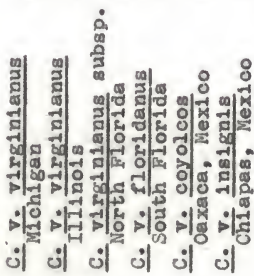

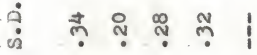

과 와 엉우 $N$

이 이 이 이 미

起 ล กิ

卉

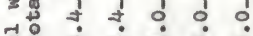

สี

청 \&

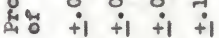

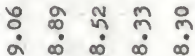

ํํㄹ

iो m.

क्ष 이 ㅎा 이 미

ลิ ธิ วิ ส

ஜ

1 ง

ฟี่

แ

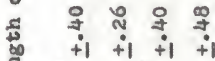

ๆ

ヘิ ที่

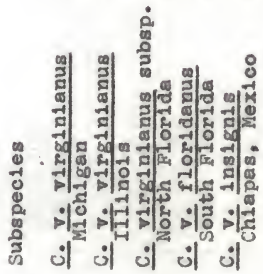


ค

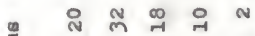

घ घा 미 미 미 미

แึ

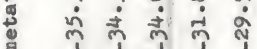

I 1 i 1 y

\&

4 ำ

岳 $+1+1+1+1$

b $\stackrel{0}{*} \%$ nn n

g

శ్

$\infty$

四

$$
\begin{aligned}
& \dot{0} \\
& \text { ง } \\
& \text { 각ㅇ } \\
& \text { 미 미 미 미 미 }
\end{aligned}
$$

发营

- $\rightarrow \frac{0}{0}$

娄点

की

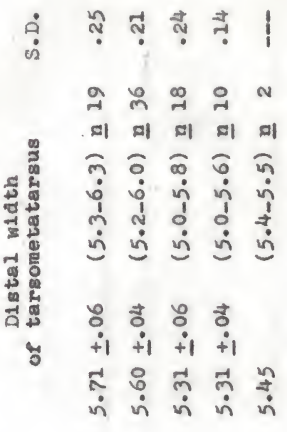

ค ैำ ำ ำ

욕 에 N

마 마 히 마 미

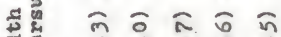

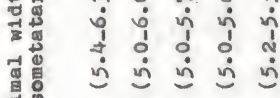

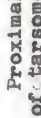

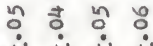

$+1+1+1+1$

ஸे

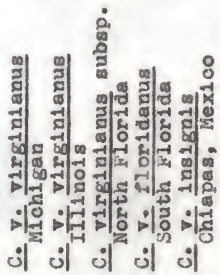




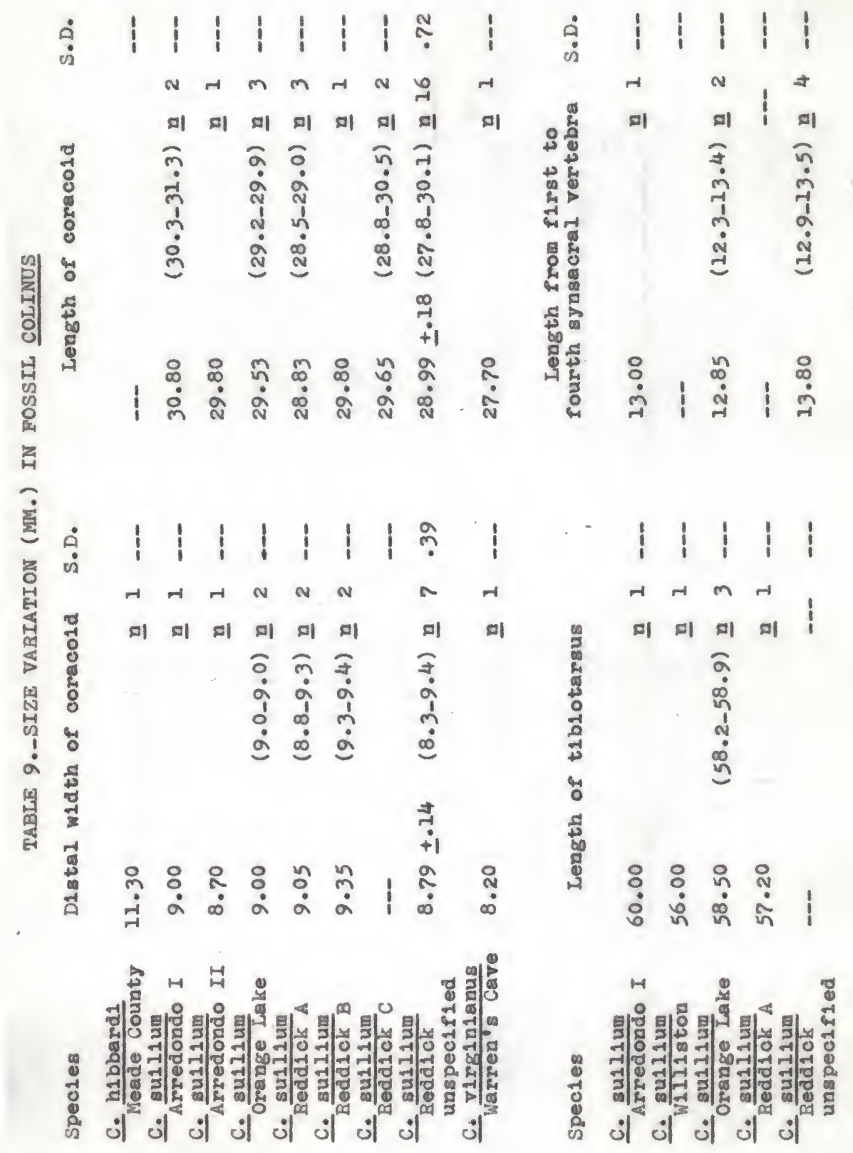




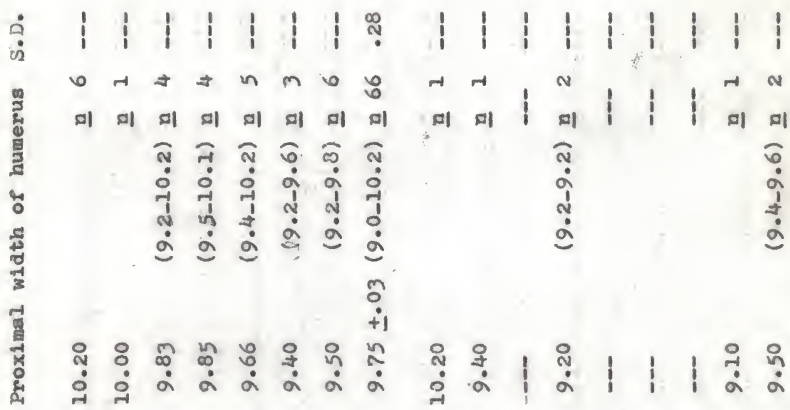

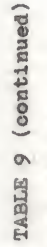

$\therefore$ i 1 i

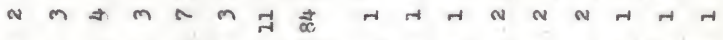

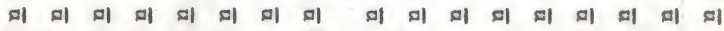

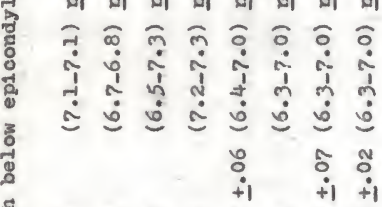

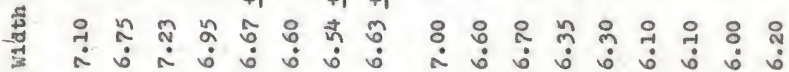

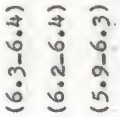

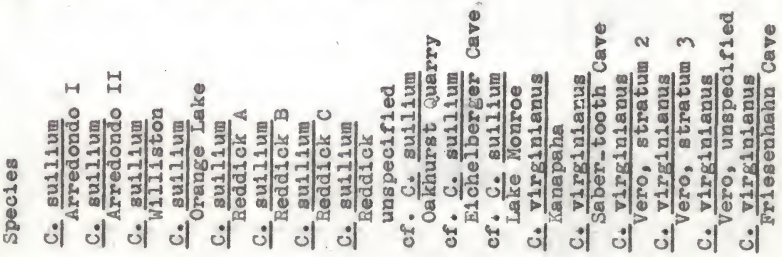



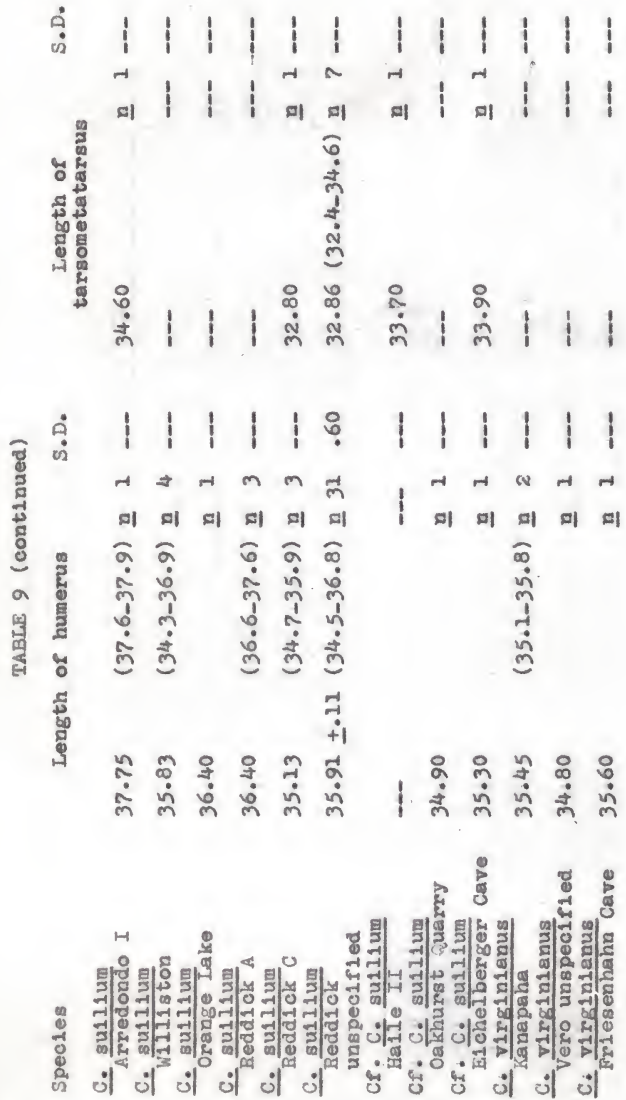

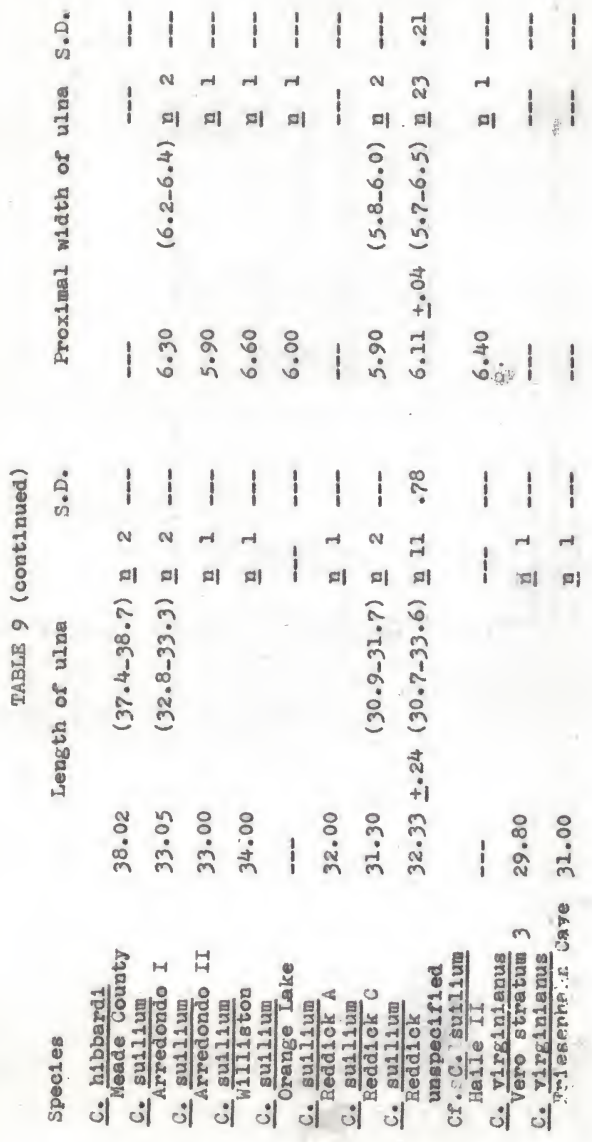

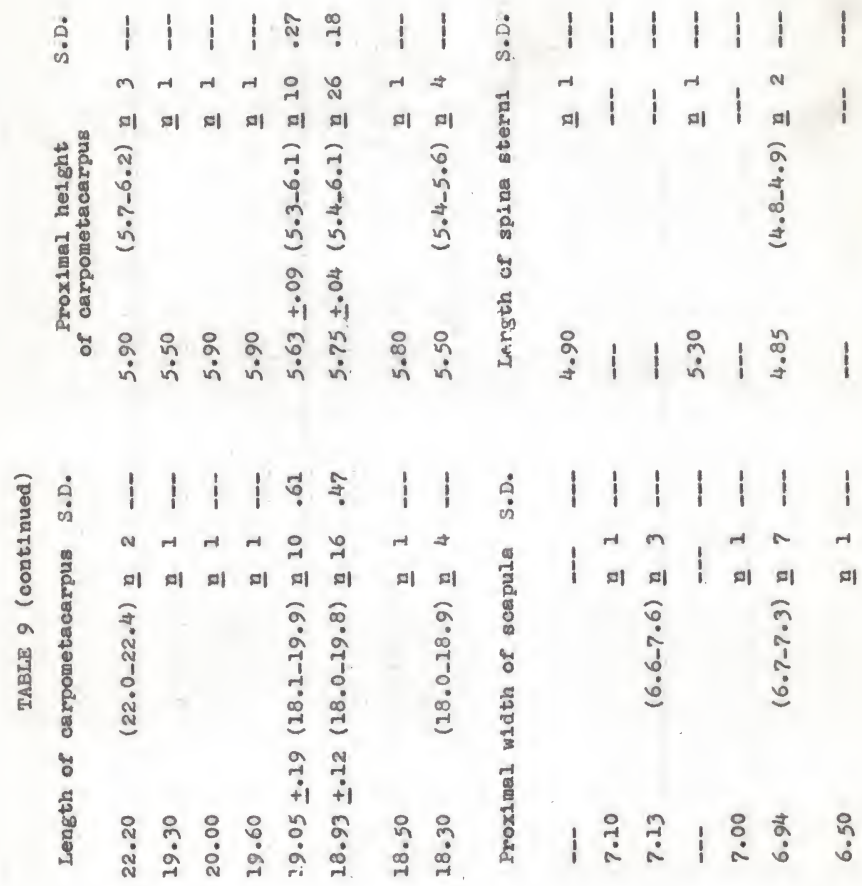

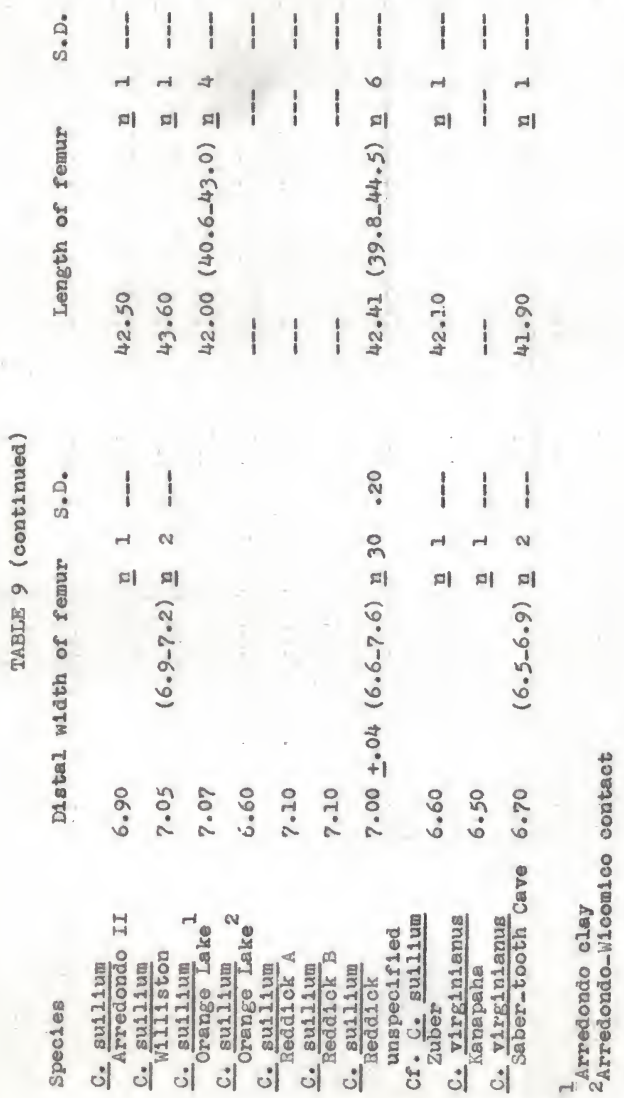


$$
\begin{aligned}
& \dot{B} 11111110 \%
\end{aligned}
$$

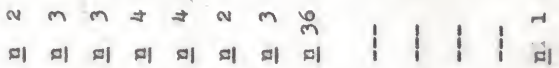

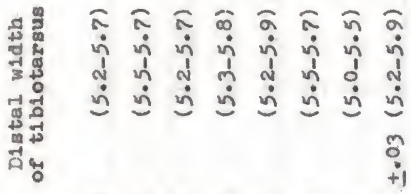

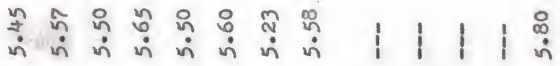

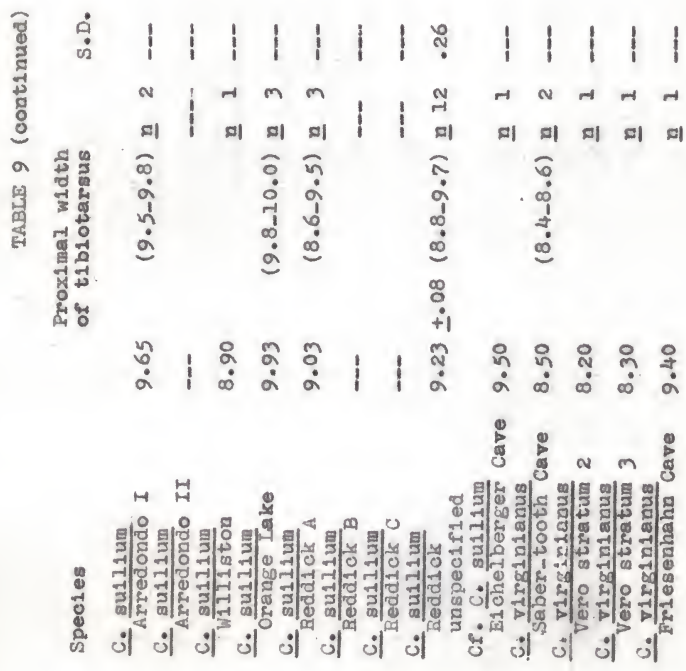


๕̊

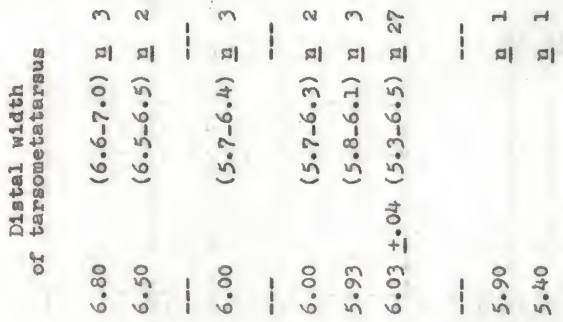

용

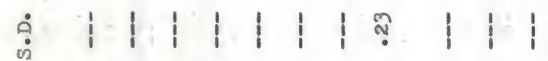

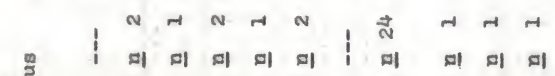

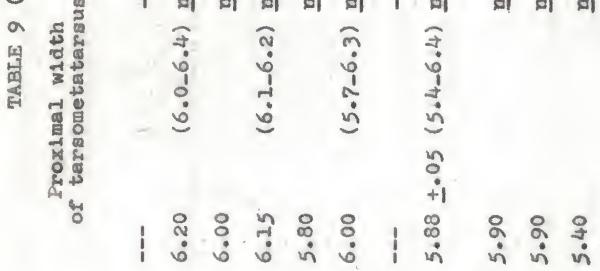

8

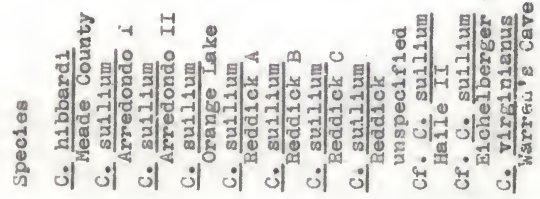




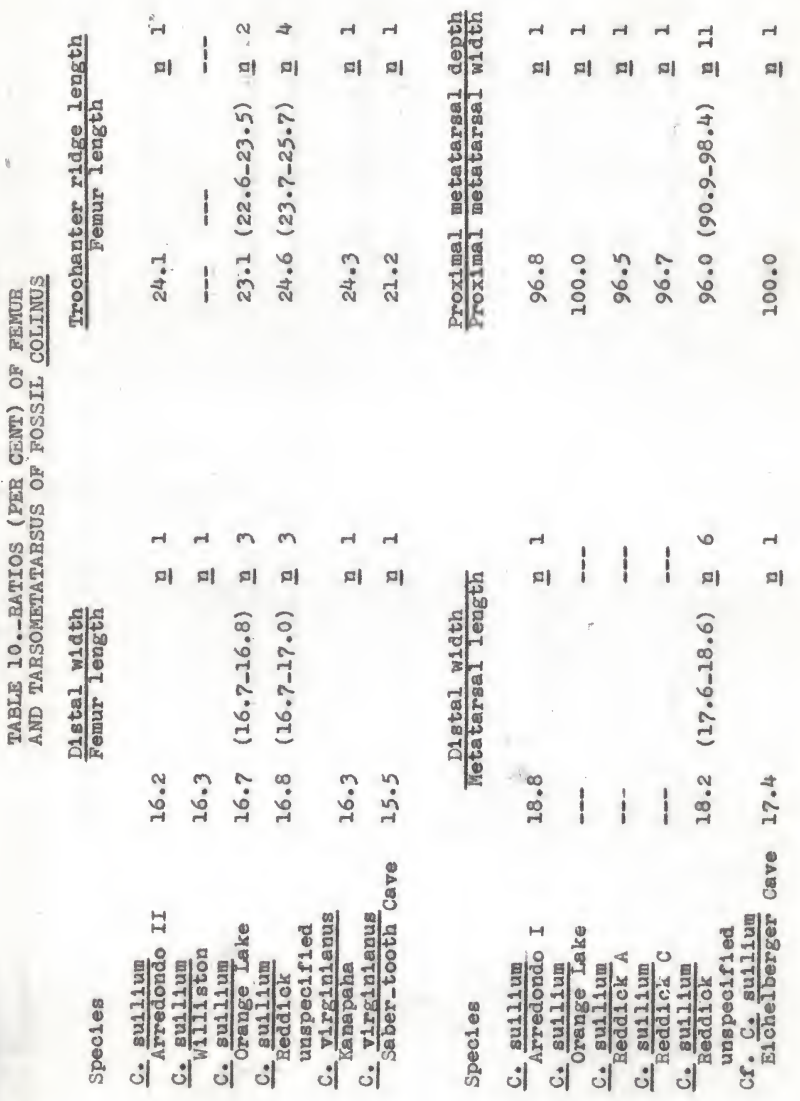




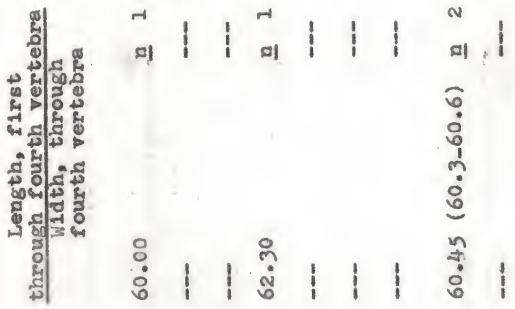

留司

코범
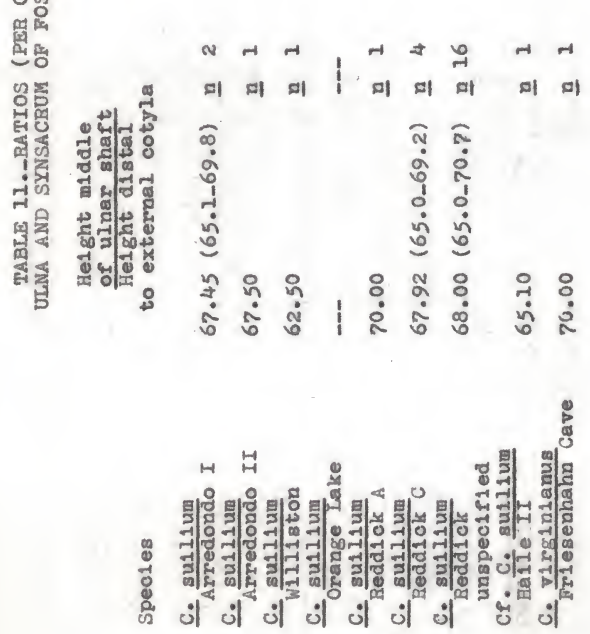

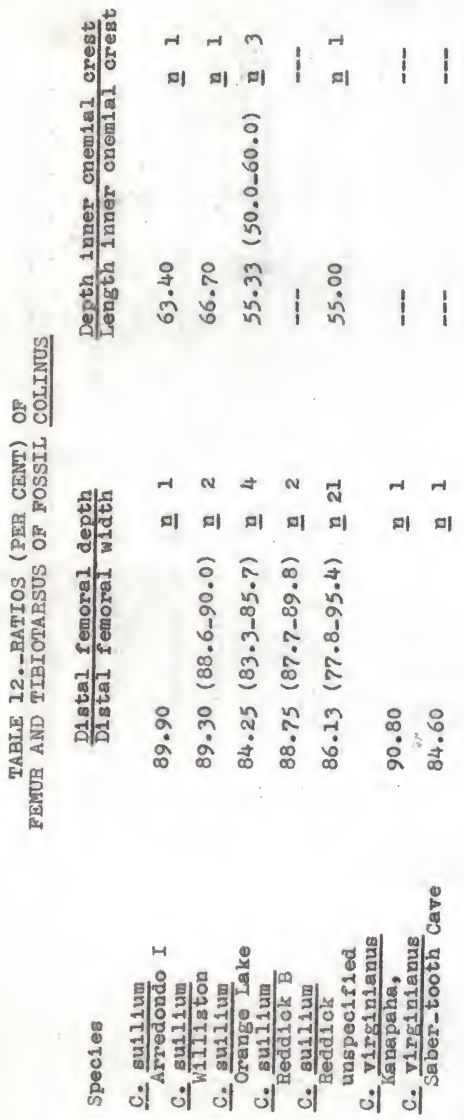
TABLE 13.-RATIOS (PER CENT) OF TARSOMETATARSUS AND SYNSACRUM OF FOSSIL COLINUS

Species

C. $\frac{\text { su111um }}{\text { Arredondo I }}$

c. su111um Orange Lake

c. sullium Reddick B

c. su1lium

C. su1l1um Redd1ck unspeolfied

cr. C. sullium

Eichelberger Cave
Midde trochlea depth D1stal wlath

$54.3(53.8-54.7)$ ․ 2

$55.1(53.2-56.9)$ 므 2

$56.3(54.0-58.6)$ ㅁ 2

$53.7(52.5-55.2)$ 끄 3

$56.3(54.0-58.6)$ 2

$54.7(51.7 .59 .0)$ 프 23 


\section{LITERATURE CITED}

Ashley, James F.

1941. A study of the structure of the humerus in the Corv1dae. Condor, vol. 43, no. 4, pp. 184-195, 7 pls.

Auffenberg, W.

1955. Glags 11zards (Ophlsaurus) in the Plelstocene and Pllocene of Florlda. Herpetologica, vol. 11, no. 3. pp. 133-136.

Ba1ley, Vernon

1928. A hybr1d scaled $x$ Gambel's quall from New Mexico. Auk, vol. 45 , no. 2, p. 210 .

Brodkorb, P1erce

1956. Ple1stocene b1rds from Elchelberger Cave, Florlda. Auk, vol. 73, no. 1, p. 136.

1957. New passerlne blrds from the Plelstocene of Reddlok, Florlda. Jour. Paleont., vol. 31 , no. 1. pp. 128_138, 1 pl., 1 flg. 1 in text.

1958. Blrds from the MIddle Pllocene of MoKay, Oregon, Condor, vol. 60 , no. 4, pp. 252-255, 1 f1g.

1959. The Ple1stocene av1faune of Arredondo, Florida. Bul1. Florlda State Mus., vol. 4, no. 9, pp. 269-291, 12 f1gs., 1 map.

1960. How many spec1es of b1rds have existed? Bull. Flor1da State Mus., vol. 5, no. 3, pp. 41-53.

Crispens, Charles $G$.

1960. Qua11s and partr1ages of North Amer1ca. Un1v. Wash. Publ. B101., vol. 20, pp. 1-125.

Delacour, Jean

1951. The pheasants of the world. Pp. 1-347, 32 pls., Country Life Ltd., London. 
DeMay, Ida S.

1941. Plelstocene blrd 11fe of the Carplnteria asphalt, California. Carn. Inst. Wash., Publ. 55, pp. $61-76 ., 4$ f1gs.

1942. An av1 fauna from Indian k1tchen middens at Buena V1sta Lake, Cal1fornia. Condor, vol. 44, no. 5 , pp. 228-230.

F1sher, Harvey I.

1953. Faunal and archeologlcal researches in Yucatan caves: Part 3. The birds. Bull. Cranbrook Inst. Se1.. no. 33, pp. 81-90.

Hellwayr, Charles E., and Boardman Conover

1942. Catalogue of birds of the Americas. F1eld Mus. Nat. H1st. Zool. Ser., vol. 13, pt. 1, no. 1, pp. 1-636.

Holman, J. A.

1958. The Plelstocene herpetofauna of Saber-tooth Cave, C1trus County, Florida. Copela, 1958, no. 4, pp. 276-280.

1959a. Amphlbians and rept1les frow the Plelstocene (IIIInolan) of W1IIIston, Florlda. Cope1a, 1959, no. 2, pp. 96-102, 1 flg.

1959b. A PIe1stocene herpetofauna near Orange Lake, Florlda. Herpetologlca, vol. 15, no. 3., pp. 121-125, i $\mathrm{f1g}$.

1959c. B1rds and mammals from the Ple1stocene of W11118. ton, Florlda. Bull. Florlde state Mus., vol. 5, no. 1, pp. 1-24, 2 pls.

Howard, H1ldegarde

1929. The arlfauna of the Emeryv1lle shellmound. Univ. Cal1f. Publ. Zool., vol. 32, no. 2, pp. 301-394, $4 \mathrm{pls}, 55 \mathrm{f1gs}$.

1930. A census of the Plelstocene blrds of Rancho La Brea from the collectlons of the Los Angeles Museum. Condor, vol. 32, no. 2, pp. 81-88, 3 I1g8.

1944. M1scellaneous avian fos812 records from Cal1forn1a. Bull. Southern Calif. Acad. Sc1., vol. 43, pt. 2, pp. 74-77, 1 pl. 
1949. Avian foss1ls from the mar1ne Plelstocene of southern Callfornia. Condor, vol. 51, no. 1, pp. $20-28$.

Hudson, George E., Patricla J. Lanzillotti, and Glen D. Edwards

1959. Muscles of the pelvic 11mb in gall1form b1rds. Amer. Midl. Nat., vol. 61, no. 1, pp. 1-67, 20 11gs.

Mayr, Ernst, anc Dean Amadon

1951. A classiflcation of recent b1rds. Amer. Mus. Nov1t., mo. 1496, pp. 1-42.

Miller, Alden H.

1944. An avifauna frow the Lower Mlocene of South Dakota. Un1v. Callf. Publ., Bull. Dept. Geol. Sc1., vol. 27 , no. 4, pp. 85-100, 8 rigs in text.

Miller, Loye H.

1911. Arifauna of the Ple1stocene cave deposits of Cal1forn1a. Un1v. Cal1f. Publ., Bull. Dept. Geol. Sc1., vol. 6, no. 16, pp. 385-400, I r1g.

1912. Contributions to av1an palaeontology from the Pac1fic Coast of North Amer1ca. Univ. Callf. Publ., Bul1. Dept. Geol. Sc1., vol. ?, no. 5, pp. 6i-115.

1914. B1rd remalns from the Pleletocene of San Pedro, Callforn1a. Un17. Cal1f. Publ., Bull. Dept. Geol. Se1., vol. 8, no. 4, pp. $31-38$.

1930. Further b1rd remalns from the upper San Pedro Ple1stocene. Condor, vol. 32, no. 2, pp. 116-118, $1 \mathrm{f1g}$.

1935. A second avifaune from the MeKittrick Ple1stocene. Condor, vol. 37, no. 2, pp. 72-79, 3 figs.

1943. The Ple1stocene b1rda of San Josec1to Cavern, Mexico. Un1r. Cal1f. Publ., Zool. Ser., vol. 47, no. 5, pp. 143-168.

1952. The ar1fauna of the Barston Miocene of Cal1fornla. Condor, vol. 54, no. 5, pp. 296-301, 2 118s. 
Miller, Loye $\mathrm{H}_{.}$, and Ide S. DeMay

1942. The foss1l blrds of Callforn1a. Univ. Callf. Publ. Zool., vol. 47, no. 4, pp. 47-142.

Milstead, W. W.

1956. Foss1l turtles of Friesenhahn Cave, Texas, w1th the desorlption of a new spec1es of Testudo. Cope1a, 1956, no. 3, pp. 162-171.

Peters, James L.

1934. Cheok-11st of birds of the world. Vol. 2, pp. 1-xv111, 1-401. Harvard Un1v. Press, Cambridge.

Rldgway, Bobert, and Herbert Frledmann

1946. The birds of North and Midale Amer1ce. U. S. Nat. Mus. Bull. 50, pt. 10, pp. 1-484, 28 f1gs.

Shufeldt, R. W.

1897. On foss11 blrd-bones obtalned by expeditions of the University of Pennsylvania from the bone caves of Tennessee. Amer. Nat., rol. 31, pp. $645-650$.

1909. Osteology of blrds. Bull. N. Y. State Mus., vol. 130 , pp. 1-135, $16 \mathrm{pls} ., 65$ f1gs. 1n text.

Sibley, Charles G.

1960. The electrophoret10 patterns of avian egg-white protelns as taxonom10 characters. Ib1s, vol. 102, no. 2, pp. 215-259, 15 :1gs.

Stebb1ns, G. L.

1947. Fividence on rates of evolution from the distr1bution of existing and fossil plant species. Ecol. Monogr., vo1. 17, pp. 149-158.

Stresemann, Erwin

1959. The status of arian systemat1cs and 1ts unsolved problems. Auk, vol. 76, no. 3, pp. 269-280.

Tordoff, Harrison B.

1951a. Osteology of Collnus hibbard1, Pllocene quall. Condor, vol. 53, no. I, pp. 23-30, 2 f1gs.

1951b. A quall from the 011gocene of Colorado. Condor, vol. 53, no. 4, pp. 203-204.

Tordoff, Harrison B., and J. B. Macdonald

1957. A new blrd (Fam1ly Cracldae) from the early Oligocene of South Dakota. Auk, vol. 74, no. 2, pp. $174-184,1$ fig. 
Welgel, Bobert $D$.

1958. Foss11 vertebrates of Vero, Florida. Unpublished doctoral dissertation, Univ. of Florida, pp. 1-87, $9 \mathrm{pls.}$

Wetmore, Alexander

1924. Foss1l b1rds from southeastern Ar1zona. Proc. U. S. Nat. Mus. vol. 64., art. 5, pp. 1-18, 9 11gs.

1930. A systematic classification for the b1rds of the world. Proc. U. S. Nat. Mus., vol. 76, art. 24, pp. 1-8.

1931. The avifauna of the Ple1stocene in Florida. Smithsonian M18c. Coll., vol. 85, no. 2, pp. 1-41, 6 pls., $26 \mathrm{flgs.}$ in text.

1932a. B1rd remains from Indian dwellings in Arizona. Condor, vol. 34, no. 3, pp. 138-139.

1932b. Additional reoords of birds from cavern deposits in New Mexlco. Condor, vol. 34, no. 3, pp. $141-142$.

1933. The Cal1fornia condor in Texas. Condor, vol. 35 , no. 1, pp. 37-38.

1934. A ross1l qua1l from Nebraska. Condor, vol. 36 , no. 1, p. $30,1 \mathrm{r} 1 \mathrm{~g}$.

1944. Remalns of birds from the Rexroad fauna of the Upper P11ocene of Kansas. Un17. Kansas Sc1. Buil., vol. 30, pt. 1, no. 9, pp. 89-105, 19 flgs.

1951. A revised classification for the blrds of the world. Sm1thsonian M1sc. Coll., vol. 117, no. 4, pp. 1-22.

1960. A classiflcation for the birds of the world. Sm1thsonlan M1se. Coll., vol. 139, no. 11, pp. 1-37.

Winge, oluf

1887. Fugle fra Knoglehuler 1 Brasillen. E Museo Lund11, vol. 1, no. 2, pp. 1-54. 


\section{BIOGRAPHICAL SKETCH}

J. Alan Holman was born in Ind1anapol1s, Ind1ana, on September 24, 1931. Undergraduate study at Franklin Col_ lege of Indiana resulted In the degree of Bachelor of Arts w1th D1stinction in B1ology in June of 1953. After graduation he served on active duty in the Un1ted States Naval Reserve unt12 1955. Graduate study was begun in September of 1955 at the UnIversity of Florlda, where the Master of Sclence degree wan reselved in June of 1957. Graduate assistantsh1ps were held at the University of Florida. He 1s currently employed as Assistant Professor of Blology at Howard College, Blrmingham, Alabama. He is a meaber of Blue Key, the Soolety of the S1gma X1, Ch1 Beta Ph1 Sc1entific Soclety, Phi S1gma and Trl Beta Blological Socletles, the American Ornithologists' Unlon, Herpetolog1sts League, American Soclety of Ichthologists and Herpetologists, Soclety of Vertebrate Paleontology, Soclety for the Study of Evolution, and the Florida Academy of Sclence. 
Th1s dissertation was prepared under the direction of the chalrman of the candidate's supervisory committee and has been approved by all members of that commlttee. It was submitted to the Dean of the College of Arts and Solences and to the Graduate Counc1l, and was approved as partial fulf1liment of the requirements for the degree of Doctor of Ph1losophy.

January, 1961

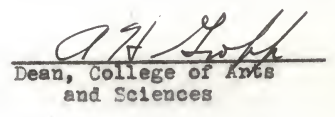

Dean, Graduate School

Supervisory Committee:
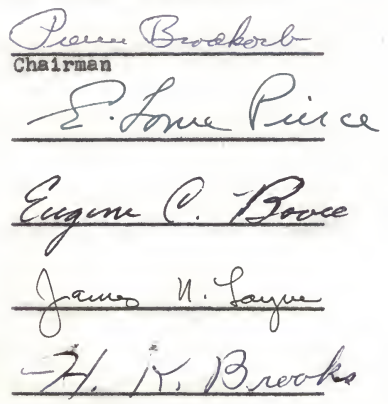